\title{
17. PETROLOGY AND GEOCHEMISTRY OF OCEANIC INTRAPLATE SHEET-FLOW BASALTS, NAURU BASIN, DEEP SEA DRILLING PROJECT LEG 891
}

\author{
P. A. Floyd, Department of Geology, University of Keele ${ }^{2}$
}

\begin{abstract}
Reentry of Hole $462 \mathrm{~A}$ during Leg 89 resulted in the penetration of a further $140 \mathrm{~m}$ of basalt sheet-flows similar to those found during Leg 61 at the same site. Twelve volcanic units ( 45 to 56 ) were recognized, comprising a series of rapidly extruded, interlayered aphyric and poorly clinopyroxene-plagioclase-olivine phyric, nonvesicular basalts. All exhibit variable, mild hydration and oxidation, relative to fresh oceanic basalts, produced under reducing, low- $\mathrm{CO}_{2}$-activity conditions within the zeolite facies. Secondary assemblages are dominated by smectites, zeolites, and pyrite, produced by low-temperature reaction with poorly oxygenated seawater. No systematic mineralogical or chemical changes are observed with depth, although thin quenched units and more massive hypocrystalline units exhibit slightly different alteration parageneses.

Chemically, the basalts are olivine- and quartz-normative tholeiites, characterized by low incompatible-element abundances, similar to mildly enriched MORB (approaching T-type), with moderate, chrondite-normalized, large-ionlithophile-element depletion patterns and generally lower or near-chrondritic ratios for many low-distribution-coefficient $\left(\mathrm{K}_{D}\right)$ element pairs. In general, relative to cyclic MORB chemical variation, they are uniform throughout, although 3 chemical megagroups and 22 subgroups are recognized. It is considered that the megagroups represent separate low-pressure-fractionated systems (olivine + plagioclase \pm clinopyroxene), whereas minor variations within them (subgroups) indicate magma mixing and generation of near-steady-state conditions. Overall, relatively minor fractionation coupled with magma mixing produced a series of compositionally uniform lavas. Parental melts were produced by similar degrees of partial melting, although the source may have varied slightly in LIL-element content.
\end{abstract}

\section{INTRODUCTION}

Extensive areas of the central and western Pacific Ocean floor are covered by the volcanic products of Cretaceous intraplate volcanism (Winterer, 1973; Larson and Schlanger, 1981; Haggerty et al., 1982). The Nauru Basin is one such area (Fig. 1), and drilling at Site 462 during DSDP Leg 61 demonstrated the existence of a thick Lower Cretaceous basaltic sill-flow complex (Larson, Schlanger, et al., 1981). Magnetic lineation patterns for the western Pacific indicate that the complex rests on Jurassic oceanic basement (Larson, 1976; Hilde et al., 1977; Larson and Schlanger, 1981). On the basis of seismic reflection data, the Nauru intraplate volcanic province extends over some $400,000 \mathrm{~km}^{2}$ (Fig. 1) and probably has a volume comparable to many continental flood basalt provinces (Tokuyama and Batiza, 1981).

Hole 462A was reentered during Leg 89 and penetrated farther into the sill-flow complex, but did not reach Jurassic oceanic basement below. Combining data for Legs 61 and 89, the sill-flow complex has a minimum thickness of $650 \mathrm{~m}$ and is composed predominantly of a lower unit of basaltic sheet-flows and an upper unit of supposedly intrusive doleritic sills. Although sedimentary interlayers with suitable fossil debris are few, faunal evidence, coupled with radiometric dating, indicates emplacement of some of the complex within the 115-110 Ma interval (Schlanger and Premoli Silva, 1981; Ozima et al., 1981), with the stratigraphically lowest part sampled during Leg 89 being lower Aptian or older (see Cas-

\footnotetext{
${ }^{1}$ Moberly, R., Schlanger, S. O., et al., Init. Repts. DSDP, 89: Washington (U.S. Govt. Printing Office).

2 Address: Dept. of Geology, University of Keele, Staffordshire, ST5 SBG U.K.
}

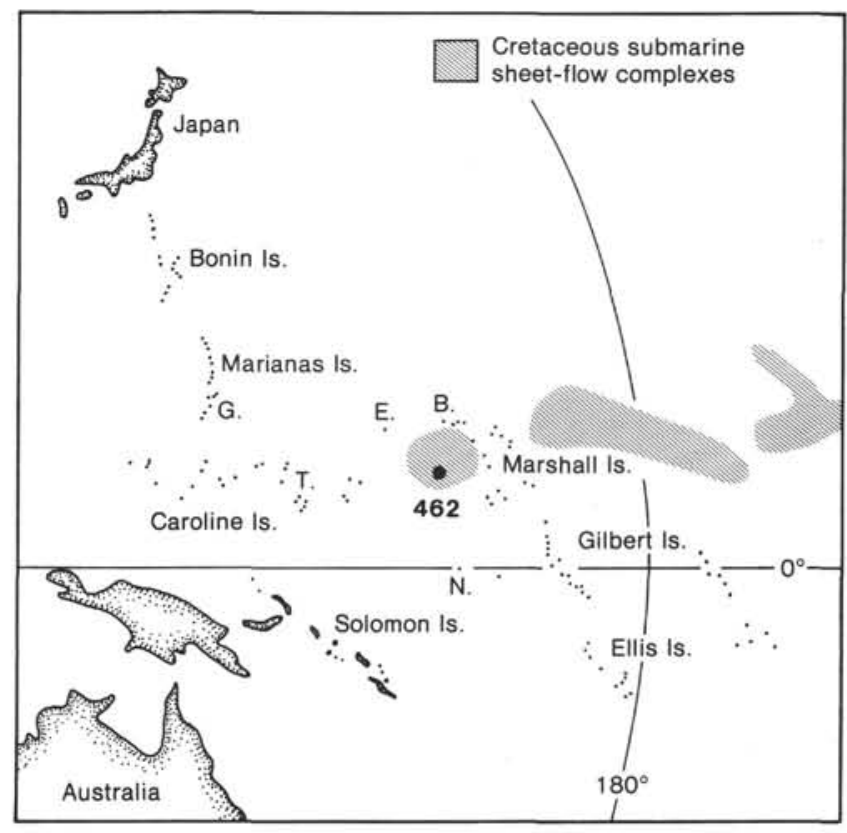

Figure 1. Locality map of the western Pacific showing position of DSDP Site 462 and extent of Cretaceous intraplate sheet-flows (after Winterer, 1973).

tillo et al., and Schlanger and Moberly, this volume, for discussions of age of the basalts).

Chemically and mineralogically, the basalts are not unlike some types of mid-ocean ridge basalts (MORB), with LIL-element patterns generally depleted relative to chondrites, and low SR isotope ratios, but they are sufficiently different in a number of respects to set them apart (Batiza et al., 1980; Batiza, 1981; Tokuyama and 
Batiza, 1981; Fujii et al., 1981; Saunders, and Castillo et al., this volume). The sheet-flows form a voluminous, chemically distinctive form of submarine intraplate volcanism, generated on preexisting ocean crust and derived from different parent magmas (and/or sources) from MORB.

This chapter describes the petrography and geochemistry of 75 basalt samples collected during Leg 89 (Table 1) from the deepest part of the sill-flow complex at Hole $462 \mathrm{~A}$, between 1072 and $1209 \mathrm{~m}$ sub-bottom depth.

\section{ANALYTICAL METHODS}

Major- and trace-element analysis was performed using a Philips PW1212 X-ray fluorescence (XRF) spectrometer calibrated against international and internal University of Keele standards of appropriate composition. Major elements were analyzed in a fused glass disc (1:5 mixture of ignited rock powder and Li metaborate flux) using method and interelement correction procedures modified after Norrish and Hutton (1969). Trace elements and $\mathrm{Na}_{2} \mathrm{O}$ were analyzed in a pressed powder pellet using the method of Leake et al. (1969). Ferrous Fe was determined by titration with potassium dichromate on a separate aliquot of sample. $\mathrm{H}_{2} \mathrm{O}^{+}$and $\mathrm{CO}_{2}$ were determined together by $\mathrm{HNC}$ Analyzer. Th, U, Ta, and $\mathrm{Hf}$ data were obtained for about half the samples by instrumental neutron activation analysis (Duffield and Gilmore, 1979) at the Universities Research Reactor, Risley, U.K.

Analytical precision (measured by the coefficient of variation; Table 2) was evaluated by analysis of 10 separate samples of an internal standard (KUM-1), and gave $\pm 1-4 \%$ for major and minor elements (including $\mathrm{FeO}$ ) and $< \pm 5 \%$ for most trace elements, except $\mathrm{La}, \mathrm{Ce}$, and $\mathrm{Nb}( \pm 10 \%)$. Light rare-earth elements (REE) analyzed by XRF spectrometry were checked by inductively coupled plasma emission (ICP) spectrometry at King's College, London (Walsh et al., 1981), and gave reasonable agreement at low concentrations, whereas XRF La values $>5 \mathrm{ppm}$ and XRF Ce values $>15 \mathrm{ppm}$ were about $20 \%$ higher than the corresponding ICP values. Full REE data will be published elsewhere; only the XRF light REE results are presented in the analytical tables.

Analytical accuracy was monitored against international basalt standards BCR-1 and BOB-1 (Table 2), and showed reasonable agreement. Selected Leg 89 samples were also analyzed in other laboratories by similar XRF techniques, and showed that the Keele data were generally comparable, except that $\mathrm{Ba}$ was erratic and probably unreliable at low concentrations, whereas $\mathrm{Sr}, \mathrm{TiO}_{2}$, and total $\mathrm{Fe}\left(\mathrm{as} \mathrm{Fe}_{2} \mathrm{O}_{3}\right)$ were systematically high by about 15,4 , and $2 \%$, respectively. Ta abundances were found to show greater variability than expected, relative to other incompatible elements; high values probably reflect contamination during crushing in a tungsten carbide swing mill.

Normative calculations were performed on analyses recalculated to an anhydrous and carbonate-free basis and a standard oxidation ratio of 0.15 (Brooks, 1976) to reduce the effects of oxidation on the norm.

Modal analysis by automatic point counter was carried out on representative samples; about 2000 points were counted in most thin sections. An error of about $\pm 3 \%$ on each mineral constituent (chart in Barringer, 1953) is probably typical, except for some of the very finegrained quench-textured samples, where identification was difficult.

\section{GENERAL CHARACTERISTICS OF VOLCANIC UNITS}

Additional to the 44 volcanic units recognized during Leg 61 (Larson, Schlanger, et al., 1981), a further 12 basaltic units (numbered 45 to 56 ) were recorded within the $140-\mathrm{m}$ section from Cores $462 \mathrm{~A}-93$ to $462 \mathrm{~A}-109$ of Leg 89 (Fig. 2). Although further examination has confirmed the presence of subunits, mineralogical changes are relatively minor, and no change has been made in the number of units previously recorded (Site 462 chapter, this volume), except that Unit 51 is no longer considered to represent pillow lavas. Petrography of the main basaltic types is described in a subsequent section.
Table 1. Keele sample numbers, corresponding DSDP sample numbers, and related data of chemically analyzed basalts from Nauru Basin, Hole 462A.

\begin{tabular}{|c|c|c|c|c|c|}
\hline $\begin{array}{c}\text { Keele } \\
\text { number }\end{array}$ & $\begin{array}{c}\text { Sample } \\
\text { (interval in } \mathrm{cm} \text { ) }\end{array}$ & $\begin{array}{l}\text { Sub-bottom } \\
\text { depth } \\
\text { (m) }\end{array}$ & $\begin{array}{l}\text { Volc. } \\
\text { unit }\end{array}$ & $\begin{array}{c}\text { Texture } \\
\text { (• modal data) }\end{array}$ & Lithology \\
\hline $462 \mathrm{~A}-1$ & $93-1,35-40$ & 1072.08 & \multirow{13}{*}{45} & •G. & ol-pl-cpx s-phyric B \\
\hline $462 \mathrm{~A}-2$ & $93-2,43-48$ & 1073.66 & & G. & ol-pl-cpx s-phyric B \\
\hline $462 \mathrm{~A}-3$ & $94-1,8-13$ & 1076.71 & & G. & ol s-phyric B \\
\hline $462 \mathrm{~A}-4$ & $94-2,24-29$ & 1078.37 & & ${ }^{\bullet} \mathrm{G}$ & ol-cpx-pl s-phyric B \\
\hline $462 \mathrm{~A}-5$ & $94-2,79-84$ & 1078.92 & & G. & ol s-phyric B \\
\hline $462 \mathrm{~A}-6$ & $94-3,126-130$ & 1080.88 & & G. & pl s-phyric B \\
\hline $462 \mathrm{~A}-7$ & $94-5,21-26$ & 1082.84 & & c. & aphyric B \\
\hline $462 \mathrm{~A}-8$ & $94-6,85-90$ & 1084.98 & & G. $v_{r}$. & aphyric B \\
\hline $462 \mathrm{~A}-9$ & $95-1,93-98$ & 1086.66 & & G. & ol-s-phyric B \\
\hline $462 \mathrm{~A}-10$ & $95-3,20-25$ & 1088.93 & & ${ }^{*} \mathrm{G}, \mathrm{vr}_{\mathrm{r}}$ & pl s-phyric B \\
\hline $462 A-11$ & $95-4,75-80$ & 1090.98 & & G. & ol-pl s-phyric B \\
\hline $462 \mathrm{~A}-12$ & $95-5,45-50$ & 1092.18 & & G. Vr. & aphyric B \\
\hline $462 \mathrm{~A} \cdot 13$ & $95-5,61-63$ & 1092.32 & & $\bullet \mathrm{Q}$ & pl-cpx phyric B \\
\hline $462 A-14$ & $95-5,76-80$ & 1092.48 & \multirow{8}{*}{46} & Q. & \multirow{8}{*}{$\begin{array}{l}\text { pl-cpx phyric B } \\
\text { ol-pl-cpxy phyric B } \\
\text { ol m-phyric B } \\
\text { cpx-pl m-phyric B } \\
\text { aphyric B } \\
\text { cpx-pl-ol s-phyric B } \\
\text { cpx-pl-ol s-phyric B } \\
\text { pl-cpx phyric B }\end{array}$} \\
\hline $462 \mathrm{~A}-15$ & $95-5,99-104$ & 1092.72 & & -Q. & \\
\hline $462 \mathrm{~A}-16$ & $95-7,38-43$ & 1095.11 & & G. 1. & \\
\hline $462 \mathrm{~A}-17$ & $96-2,122-127$ & 1097.64 & & G. & \\
\hline $462 \mathrm{~A}-18$ & $97-1,71-76$ & 1104.74 & & - G. & \\
\hline $462 \mathrm{~A}-19$ & $97-5,69-74$ & 1110.72 & & G. & \\
\hline $462 \mathrm{~A}-20$ & $98-6,5-10$ & 1120.78 & & $\cdot \mathrm{G}$ & \\
\hline $462 \mathrm{~A}-21$ & $98-6,41-46$ & 1121.14 & & ${ }^{\circ} \mathrm{Q}$ & \\
\hline $462 \mathrm{~A}-22$ & $99-2,6-11$ & 1123.89 & 47 & ${ }^{\circ} \mathrm{Q}$ & pl-ol-cpx phyric B \\
\hline $462 A-23$ & $100-2,61-66$ & 1133.64 & \multirow{19}{*}{48} & •. v. & aphyric B \\
\hline $462 \mathrm{~A}-24$ & $101-1,6-10$ & 1134.58 & & i. & aphyric B \\
\hline $462 \mathrm{~A} \cdot 2 \mathrm{~S}$ & $101-1,108-113$ & 1135.60 & & I. v. & aphyric B \\
\hline $462 A-26$ & $101-2,43-47$ & 1136.45 & & 1. & aphyric B \\
\hline $462 \mathrm{~A}-27$ & $101-2,117-122$ & 1137.20 & & •I. & aphyric B \\
\hline $462 \mathrm{~A}-28$ & $101-3,35-40$ & 1137.88 & & Q. v. & cpx s-phyric B \\
\hline $462 \mathrm{~A}-29$ & $101-3,123-128$ & 1138.76 & & Q. & aphyric B \\
\hline $462 \mathrm{~A}-30$ & $101-4,57-61$ & 1139.59 & & I. & aphyric B \\
\hline $462 \mathrm{~A}-31$ & $101-4,115-120$ & 1140.17 & & - $\mathrm{I}$. & aphyric B \\
\hline $462 \mathrm{~A}-32$ & $101-5,52-56$ & 1141.04 & & i. & aphyric B \\
\hline $462 \mathrm{~A}-33$ & $102-1,35-39$ & 1143.27 & & i. & aphyric B \\
\hline $462 A-34$ & $102-1,112-116$ & 1144.04 & & • & aphyric B \\
\hline $462 \mathrm{~A}-35$ & $102-2,54-59$ & 1144.96 & & i. & aphyrix B \\
\hline $462 A-36$ & $102-2,134-139$ & 1145.77 & & i. & aphyric of (?) B \\
\hline $462 \mathrm{~A}-37$ & $102-3,82-86$ & 1146.74 & & i. & aphyric B \\
\hline $462 A-38$ & $102-3,143-147$ & 1147,35 & & $\cdot \mathrm{G}$ & aphyric ol (?) B \\
\hline $462 \mathrm{~A}-39$ & $102-4,11-15$ & 1147.53 & & G. & ol(?)-cpx s-phyric B \\
\hline $462 \mathrm{~A}-40$ & $102-4,51-55$ & 1147.93 & & ${ }^{\circ} \mathrm{Q}$. & ol-pl-cpx m-phyric B \\
\hline $462 \mathrm{~A}-41$ & $102-4,59-63$ & 1148.01 & & ${ }^{\circ} \mathrm{Q}$. & cpx-pl-ol m-phyric \\
\hline $462 \mathrm{~A}-42$ & $102-4,95-100$ & 1148.38 & \multirow{5}{*}{49} & Q. & \multirow{5}{*}{$\begin{array}{l}\text { ol-pl-cpx m-phyric B } \\
\text { ol-pl-cpx s-phyric B } \\
\text { ol-pl-cpx phyric B } \\
\text { ol-pl-cpx s-phyric B } \\
\text { ol-pl-cpx s-phyric B }\end{array}$} \\
\hline $462 \mathrm{~A}-43$ & $102-4,131-136$ & 1148.74 & & ${ }^{\circ} \mathrm{Q} . \mathrm{v}$ & \\
\hline $462 \mathrm{~A}-44$ & $102-5,5-9$ & 1148.97 & & Q. S. & \\
\hline $462 \mathrm{~A}-45$ & $102-5,33-36$ & 1149.24 & & Q. & \\
\hline $462 \mathrm{~A}-46$ & $103-1,24-29$ & 1152.27 & & ${ }^{\circ} \mathrm{Q}$ & \\
\hline $462 \mathrm{~A}-47$ & $103-1,68-73$ & 1152.71 & \multirow{3}{*}{50} & Q. v. & \multirow{3}{*}{$\begin{array}{l}\text { ol-pl-cpx phyric B } \\
\text { pl-cpx m-phyric B } \\
\text { cpx s-phyric B }\end{array}$} \\
\hline $462 \mathrm{~A}-48$ & $103-1,107-112$ & 1153.10 & & *Q. v. & \\
\hline $462 \mathrm{~A}-49$ & $104-1,30-34$ & 1161.52 & & G. Vr. & \\
\hline 462A-50 & $104-1,40-44$ & 1161.62 & & Q. v. & pl-cpx m-phyric B \\
\hline $462 \mathrm{~A}-51$ & $104-1,67-71$ & 1161.89 & & -Q. S. & ol-pl-cpx m-phyric B \\
\hline $462 \mathrm{~A}-52$ & $104-1,81-85$ & 1162.51 & 51 & •Q. $v$ & pl-cpx-ol s-phyric B \\
\hline $462 A-53$ & $104-2,2-3$ & 1162.73 & & Q. v. & cpx-pl m-phyric B \\
\hline 462A-54 & $104-2,128-133$ & 1164.01 & & •QQ $\mathrm{v}$. & cpx-pl m-phyric B \\
\hline 462A-55 & $105-1,52-56$ & 1170.84 & & "Q. $\mathrm{v}$. & pl-cpx m-phyric B \\
\hline $462 A-56$ & $105-1,98-102$ & 1171.30 & & -Q. v. & aphyric B \\
\hline $462 A-57$ & $105-2,58-63$ & 1172.40 & & Q. v. & aphyric B \\
\hline 462A-58 & $105-2,122-126$ & 1173.04 & & i. & aphyric B \\
\hline $462 \mathrm{~A}-59$ & $105-3,50-54$ & 1173.82 & & I. & aphyric B \\
\hline $462 \mathrm{~A}-60$ & $106-1,36-40$ & 1174.68 & & I. & aphyric B \\
\hline $462 \mathrm{~A}-61$ & $106-1,129-133$ & 1175.61 & $\$ 2$ & ${ }^{\circ} \mathrm{Q}$. & aphyric B \\
\hline $462 \mathrm{~A}-62$ & $106-2,106-110$ & 1176.88 & & $\mathrm{v}$. & aphyric D \\
\hline $462 A-63$ & $106-3,4-8$ & 1177.36 & & •v. G. & aphyric D \\
\hline $462 \mathrm{~A}-64$ & $106-3,47-51$ & 1177.79 & & v. & aphyric D \\
\hline $462 \mathrm{~A}-65$ & $108-1,17-22$ & 1189.70 & & I. & aphyric B \\
\hline $462 \mathrm{~A}-66$ & $108-1,79-84$ & 1190.32 & & $\cdot v$ & aphyric B \\
\hline $462 \mathrm{~A}-67$ & $108-2,40-44$ & 1191.42 & & v. G. & aphyric B \\
\hline $462 \mathrm{~A}-68$ & $108-2,66-70$ & 1191.68 & 53 & Q. v. & pl-cpx m-phyric B \\
\hline $462 \mathrm{~A}-69$ & $108-2,125-128$ & 1192.27 & & ${ }^{-\mathrm{G}}$. & pl-cpx s-phyric B \\
\hline $462 \mathrm{~A} \cdot 70$ & $108-3,28-30$ & 1192.79 & & Q. v. & pl-cpx m-phyric B \\
\hline $462 \mathrm{~A}-71$ & $108-3,75-78$ & 1193.27 & 54 & - G. & pl-cpx m-phyric B \\
\hline $462 \mathrm{~A}-72$ & $109-1,113-117$ & 1199.85 & & G. & pl-cpx m-phyric B \\
\hline $462 \mathrm{~A}-73$ & $109-2,39-43$ & 1200.61 & ss & ${ }^{\circ} \mathrm{G}$ & pl-cpx s-phyric B \\
\hline $462 \mathrm{~A} \cdot 74$ & $109-2,144-149$ & 1201.67 & & Q.v. & pl-cpx phyric B \\
\hline 462A-75 & $109-3,112-116$ & 1202.84 & 56 & $\bullet^{\circ} \mathrm{Q}$ & pl-cpx m-phyric B \\
\hline
\end{tabular}

Note: $\mathrm{pl}$ - plagioclase, $\mathrm{cpx}=$ clinopyroxene, ol = olivine; - -phyric $=$ sparsely phyric, $\mathrm{m}$-phyric $=$ moderately phyric. $\mathrm{B}=$ basalt, $\mathrm{D}=$ dolerite. Textures: $\mathrm{V}_{\mathrm{r}}=$ vesicular, $\mathrm{I} .=$ intersertal $\mathrm{G} .=$ granular, $\mathrm{V} .=$ variolitic, $\mathrm{S} .=$ spherulitic, $\mathrm{Q} .=$ quench (skeletal and $/$ or plumose crystals \pm altered glass). 
Table 2. Accuracy, precision, and detection limits of Keele internal standard (KUM-1) and determined values for international standards BCR-1 and BOB-1.

\begin{tabular}{|c|c|c|c|c|c|c|c|c|}
\hline & \multicolumn{4}{|c|}{ KUM-1 } & \multicolumn{2}{|c|}{ BCR-1 } & \multicolumn{2}{|c|}{ BOB-1 } \\
\hline & $\bar{x}$ & S. d. & C. $v$. & D. I. & S. $r$. & $\mathbf{R}$ & S. r. & $\mathbf{R}$ \\
\hline $\mathrm{SiO}_{2}$ & 46.40 & 0.13 & 0.3 & - & 54.83 & 54.50 & 50.38 & 50.60 \\
\hline $\mathrm{TiO}_{2}$ & 2.61 & 0.05 & 1.9 & - & 2.21 & 2.20 & 1.35 & 1.45 \\
\hline $\mathrm{Al}_{2} \mathrm{O}_{3}$ & 14.92 & 0.21 & 1.4 & - & 13.57 & 13.61 & 16.19 & 14.41 \\
\hline $\mathrm{Fe}_{2} \mathrm{O}_{3}$ & 1.31 & 0.02 & 1.5 & - & 3.49 & 3.68 & 3.12 & 3.01 \\
\hline $\mathrm{FeO}$ & 8.76 & 0.04 & 0.4 & - & 8.83 & 8.80 & 5.49 & 5.36 \\
\hline $\mathrm{MnO}$ & 0.25 & 0.01 & 2.8 & - & 0.18 & 0.18 & 0.15 & 0.17 \\
\hline $\mathrm{MgO}$ & 8.38 & 0.88 & 0.9 & - & 3.56 & 3.46 & 7.63 & 8.45 \\
\hline $\mathrm{CaO}$ & 6.68 & 0.11 & 1.6 & - & 6.88 & 6.92 & 11.68 & 11.23 \\
\hline $\mathrm{Na}_{2} \mathrm{O}$ & 3.60 & 0.16 & 4.4 & - & 3.20 & 3.27 & 3.01 & 3.17 \\
\hline $\mathrm{K}_{2} \mathrm{O}$ & 1.44 & 0.01 & 0.8 & - & 1.79 & 1.70 & 0.39 & 0.31 \\
\hline $\mathrm{P}_{2} \mathrm{O}_{5}$ & 0.55 & 0.02 & 3.6 & - & 0.35 & 0.36 & 0.15 & 0.15 \\
\hline $\mathrm{H}_{2} \mathrm{O}^{+}$ & 3.47 & 0.13 & 3.7 & - & 0.75 & 0.77 & 0.40 & - \\
\hline $\mathrm{Ba}$ & 619 & 13.2 & 2 & 35 & 678 & 675 & 52 & 60 \\
\hline $\mathrm{Ce}$ & 81 & 8.0 & 10 & 7 & 58 & 54 & 17 & 15 \\
\hline $\mathrm{Cr}$ & 259 & 3.2 & 1 & 1 & 20 & 18 & 250 & 280 \\
\hline $\mathrm{La}$ & 37 & 3.1 & 8 & 5 & 29 & 26 & 8 & 7 \\
\hline $\mathrm{Nb}$ & 38 & 2.0 & 5 & 2 & 11 & 13 & 6 & 6 \\
\hline $\mathrm{Nd}$ & 27 & 2.4 & 9 & 5 & 28 & 29 & 11 & - \\
\hline $\mathrm{Ni}$ & 168 & 3.6 & 2 & 2 & 17 & 16 & 108 & 105 \\
\hline Rb & 28 & 1.5 & 5 & 3 & 45 & 47 & 5 & 5 \\
\hline $\mathrm{Sc}$ & 25 & 0.5 & 2 & 3 & 31 & 33 & 32 & - \\
\hline $\mathrm{Sr}$ & 513 & 4.8 & 1 & 4 & 349 & 330 & 208 & 201 \\
\hline $\mathrm{Y}$ & 31 & 1.2 & 4 & 2 & 38 & 37 & 26 & 28 \\
\hline $\mathrm{Zr}$ & 209 & 3.9 & 2 & 7 & 189 & 185 & 105 & 115 \\
\hline
\end{tabular}

Note: $\bar{x}=$ mean of 10 replicates $;$ S. $\mathrm{d} .=$ standard deviation; C. v. $=\%$ coefficient of variation; D. I. = detection limits; $\mathrm{S} . \mathrm{r}$. = single result; $\mathrm{R}=$ recommended values.

A summary of the features defining the upper and lower boundaries of the volcanic units is given in Table 3; criteria for the recognition of separate units are based on (1) volcaniclastic sediment interlayers, (2) development of quenched glassy or chilled margins, and (3) mineralogical and textural variations. The presence of three thin reworked hyaloclastite layers between Units 45 and 46,46 and 47 , and 47 and 48 provides clear evidence of minor lulls in eruptive activity, confirmed by significant breaks in stable magnetic inclinations at the same boundaries. In general, the observed volcanic units correlate well with the determined magnetic units, as shown in Figure 2. The nongrouping in Magnetic Unit 2 probably reflects the presence of a number of subunits observed at the top of Volcanic Unit 46.

All the volcanic units are basaltic and considered to represent sheet flows rather than pillow lavas or sills (Site 462 chapter, this volume), and as such are a continuation downward of the type B flows of Leg 61 (Batiza, 1981). In general terms, they show a crude alternation of relatively thick aphyric holocrystalline and hypocrystalline basalt units and thinner, variably phyric, generally quench-textured units. The aphyric units invariably increase in grain size toward the center, and are characterized by intersertal and granular textures, although wedge-shaped skeletal or serrated plagioclase is common throughout. Any interstitial glass is always altered to palagonite, and may be crowded with magnetite granules. These units have cooled relatively slowly, not only because they are thick and massive, but because they were rapidly blanketed and insulated by successive flows, as the lack of reworked or oxidized tops suggests. On the other hand, the phyric units contain glass, skeletal cli- nopyroxene, and plagioclase microlites, and exhibit various quench textures throughout, indicative of rapid but variable rates of cooling. Variolitic textures composed of clinopyroxene and plagioclase intergrowths are typical, whereas true spherulites are only occasionally present, preserved in glassy margins. Glomerocrystic groups of clinopyroxene and plagioclase are common; isolated microphenocrysts of olivine are rarer, and appear to be concentrated more in the upper volcanic units than the other phenocryst phases. The phyric units represent packets of rapidly extruded thin lava flows derived from a magma chamber or chambers that had undergone some degree of crystal fractionation. Mineralogically, they are dominated by clinopyroxene, which may exhibit three morphologies within the one flow: large subhedral crystals in glomerocrystic groups; smaller, equigranular grains; and quenched plumose or sheaf variolites. Taken in order, these forms may represent three crystallization episodes-in the magma chamber, during subsequent upward transport toward the surface in feeder channels, and finally on rapid quenching by seawater.

Overall, the paucity of sediment interlayers, thick flow breccias, and hyaloclastites, together with the relatively fresh nature of the lavas, suggests rapid effusion of comparatively fluid basalt that produced a lava pile at a minimum rate of about $130 \mathrm{~m} / \mathrm{m}$.y. The widespread development of the lavas in the Nauru Basin and their relatively uniform character suggest that they are sheet flows derived from fissures rather than central volcanoes.

\section{MINERALOGICAL AND CHEMICAL ASPECTS OF ALTERATION}

This section describes the general petrographic features and overall chemical effects of alteration, as related to the mode of occurrence, depth in the lava pile, and physical parameters. The chemistry of selected secondary phases is outlined by Floyd and Rowbotham (this volume); the lack of extensive and progressive alteration precludes detailed comment on chemical effects often seen in altered ocean-floor basalts (e.g., Hart et al., 1974; Humphris and Thompson, 1978).

\section{General Comments}

The degree of alteration in the basalt flows is generally low. Variably colored smectites and palagonite are the main alteration products; zeolites, celadonite, carbonate, quartz, and $\mathrm{K}$-feldspar are not very common, and $\mathrm{Fe}$ oxides are uncommon or absent (Table 4). Pyrite is abundant as fracture fillings, and is invariably associated with a dark green smectite. Other vein material consists of zeolites, calcite, and quartz. The general lack of visible patchy discoloration caused by alteration, or of haloes and zones adjacent to fractures, is principally a consequence of the nonoxidative nature of the basalt alteration and thus the paucity of red Fe oxides. Chemically the basalts are mildly oxidized and hydrated, whereas the $\mathrm{CO}_{2}$ content is very low and reflects the lack of secondary replacing carbonate in the rock matrix. Mineralogically and chemically the alteration is typical of low-temperature, post-solidification reaction with cold seawater under largely nonoxidative, zeolite-facies con- 


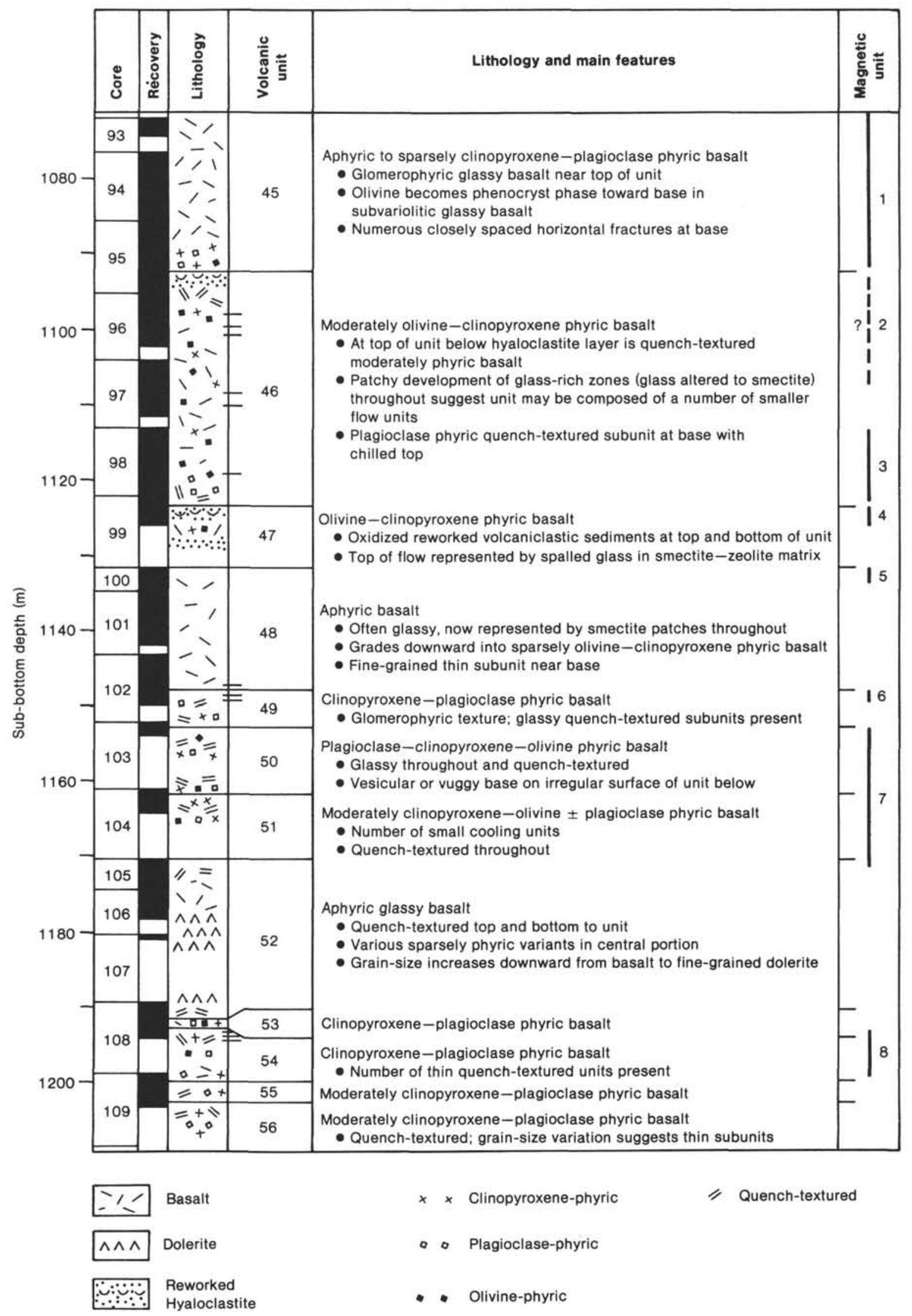

Figure 2. Lithologic and magnetic log, Hole 462A. 
Table 3. Thickness, location, and nature of the boundaries between volcanic units, Hole $462 \mathrm{~A}$.

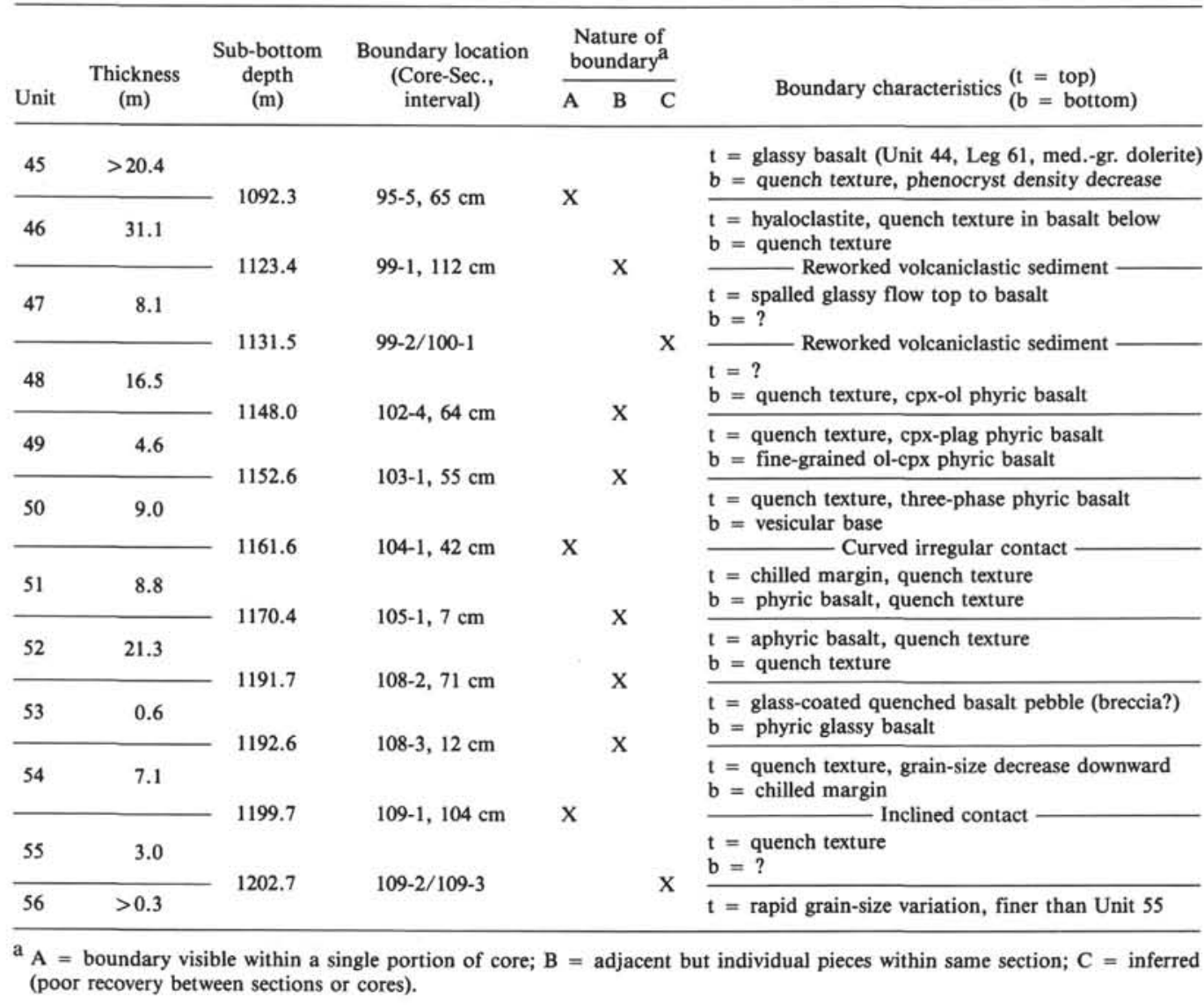

ditions. Similar low-grade submarine "weathering" at several DSDP sites drilled in oceanic basement has been described, although the degree of oxidation is often more variable and extensive (e.g., Andrews et al., 1977; Pritchard et al., 1979; Humphris, Thompson, and Marriner, 1980).

The low degree of alteration, even at some flow junctions, is probably a consequence of effusion of lava so rapid and continuous that successive flows effectively insulated those below from prolonged reaction with seawater after quenching. Also, the lack of channelways, such as clastic sediment interlayers, breccia zones, or extensive fracturing in the basalt pile, would restrict the circulation of large quantities of seawater. But seawater must have initially penetrated the pile via lava flow boundaries and subsequently through subhorizontal and nearvertical open fracture systems until they became filled with deposited material.

\section{Chemical Features}

The distribution of chemical parameters typifying alteration $\left(\mathrm{Fe}_{2} \mathrm{O}_{3} / \mathrm{FeO}, \mathrm{H}_{2} \mathrm{O}^{+}, \mathrm{CO}_{2}\right)$ is shown in Figure 3, and demonstrates the more hydrated and carbonated nature of the upper portion of the lava pile sampled on Leg 61. The average $\mathrm{Fe}_{2} \mathrm{O}_{3} / \mathrm{FeO}$ ratio $(0.5)$ and $\mathrm{H}_{2} \mathrm{O}^{+}$ content $(1.2 \mathrm{wt} . \%)$ of the Leg 89 samples are higher than in fresh MORB $\left(<0.3 \mathrm{Fe}_{2} \mathrm{O}_{3} / \mathrm{FeO}\right.$ [Miyashiro et al., 1969] and $0.2-0.4$ wt. $\% \mathrm{H}_{2} \mathrm{O}$ [Moore, 1970; Moore and Schilling, 1973]) or Hawaiian intraplate basalts (0.5-0.7 wt.\%
$\mathrm{H}_{2} \mathrm{O}$ [Delaney et al., 1978]). As shown in Figure 4, there exists between the oxidation ratio and hydration a crude positive relationship more typical of low-temperature submarine alteration than of higher-temperature hydrothermal metamorphism, which is characterized more by higher and progressive hydration (Miyashiro et al., 1971).

The highly variable $\mathrm{K} / \mathrm{Rb}$ ratio and its trend relative to K (Fig. 5) are also characteristic of low-grade alteration, and are mirrored by young ocean crust (Floyd and Fuge, 1982). The low-temperature uptake of $\mathrm{K}$ by oceanic basalts and, in particular, by glassy pillow lava selvages, is well documented (e.g., Hart and Nalwalk, 1970; Hart et al., 1974), and occurs mainly in altered glass, abundant clays, and, to a lesser extent, in minor K-bearing zeolites and $\mathrm{K}$-feldspar. The highest $\mathrm{K}$ values in the Leg 89 basalts correspond to plagioclase-rich alteration domains within holocrystalline basalt near the top of Unit 52, and reflect the development of much brown smectite, celadonite, and minor secondary K-feldspar.

Extensive hydration under low-temperature conditions causes many elements to be mobile and to exhibit progressive gains or losses relative to fresh materials (Humphris and Thompson, 1978). The main chemical effects of alteration in Leg 89 basalts are the development of erratic or scattered nonmagmatic distributions of $\mathrm{K}, \mathrm{Rb}$, $\mathrm{Ba}, \mathrm{Sr}$, and possibly $\mathrm{U}$, and, to a lesser extent, of total $\mathrm{Fe}, \mathrm{MgO}$, and $\mathrm{Ni}$. Other elements appear to be stable, with element pairs showing good coherence or distributions that can be attributed to magmatic processes. The 

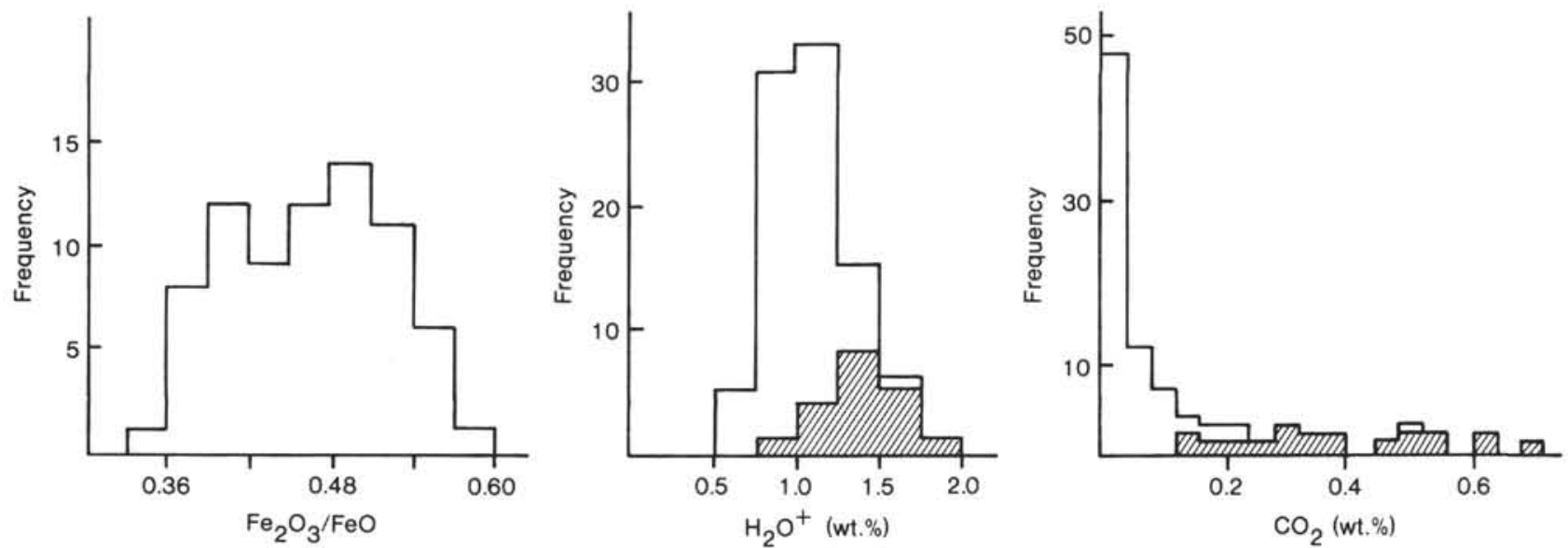

Leg 61 data

Leg 89 data

Figure 3. Histograms comparing distribution of alteration parameters in Leg 61 (data from Larson, Schlanger, et al., 1981) and Leg 89 (this work) samples.

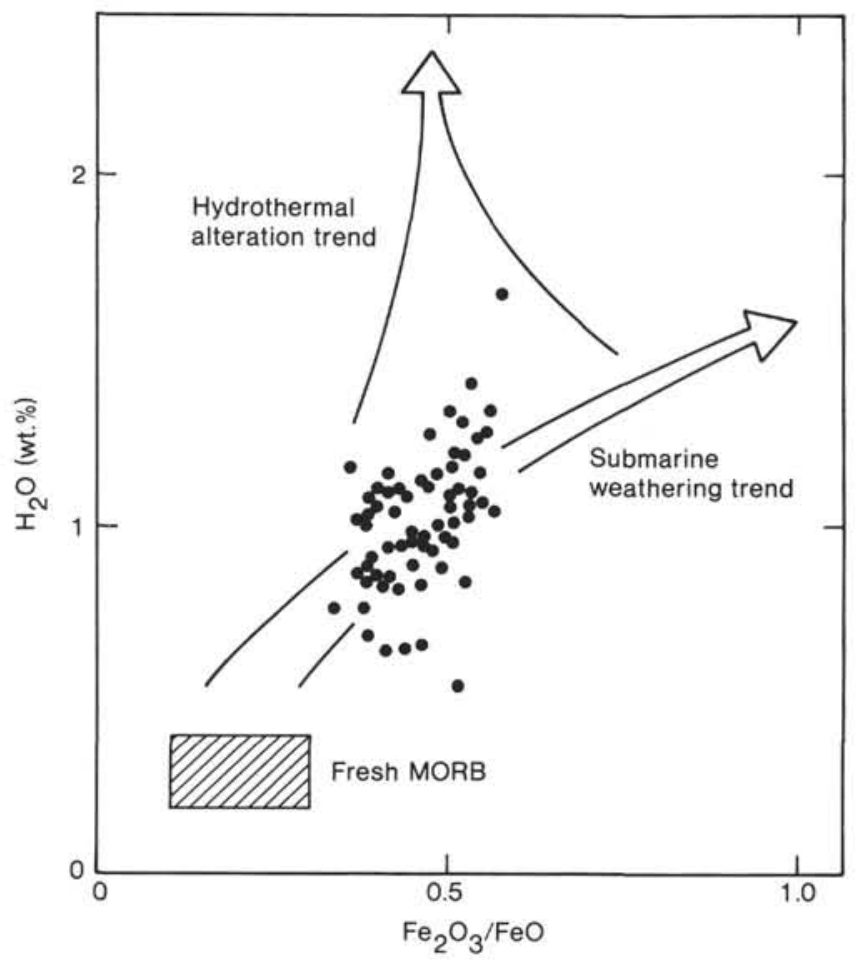

Figure 4. Hydration $\left(\mathrm{H}_{2} \mathrm{O}^{+}\right)$and oxidation $\left(\mathrm{Fe}_{2} \mathrm{O}_{3} / \mathrm{FeO}\right)$ of Hole $462 \mathrm{~A}$ basalts relative to typical trends caused by low-temperature submarine weathering and high-temperature hydrothermal alteration of oceanic basalts (Floyd and Tarney, 1979).

degree of alteration is too low and elemental variation too limited to permit recognition of any definite trends with progressive hydration for the mobile elements. It is the development of smectite that causes hydration (together with minor increases in $\mathrm{K}$ ), and when smectite replaces olivine, the $\mathrm{Ni}$ is redistributed. Other major oxides are generally undisturbed, although the $\mathrm{FeO}^{*} / \mathrm{MgO}$

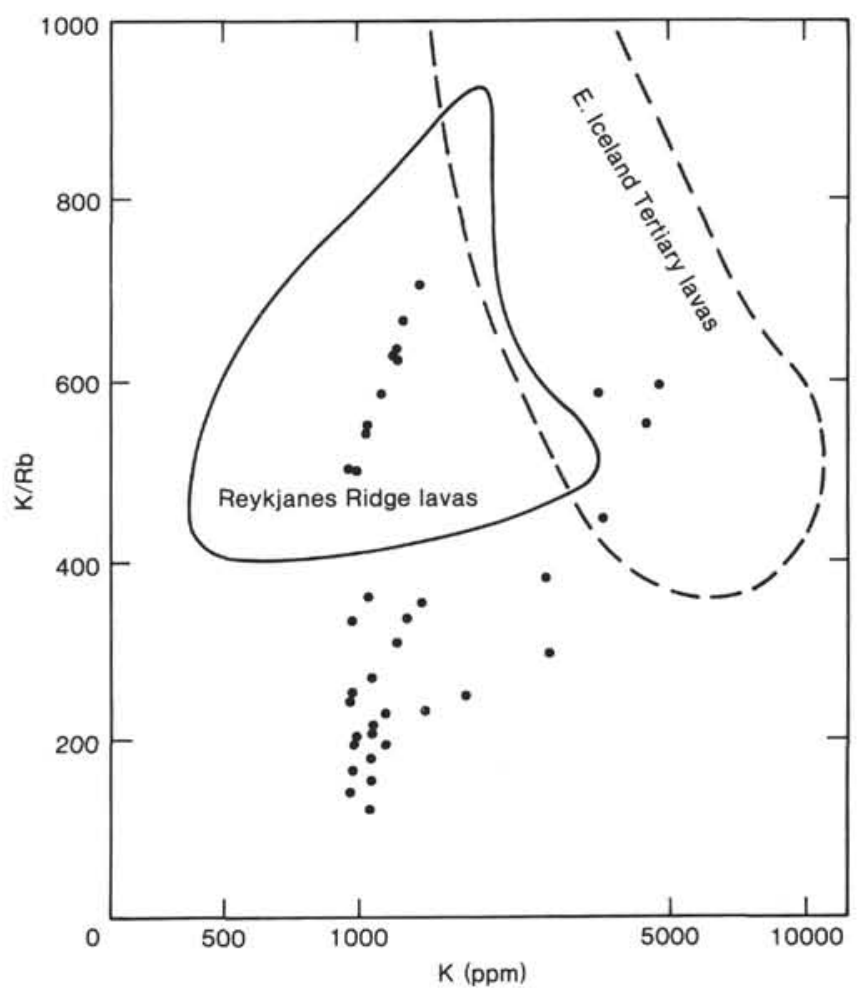

Figure 5. Typical low-temperature variation of $\mathrm{K} / \mathrm{Rb}$ and $\mathrm{K}$ in Hole $462 \mathrm{~A}$ basalts relative to Reykjanes Ridge basalts (low-grade alteration) and eastern Iceland lava flows (higher-grade hydrothermal alteration) (Floyd and Fuge, 1982).

ratio, often used as differentiation index, decreases with progressive hydration (especially in Units 46 and 48), such that the most altered basalts are apparently characterized chemically as the least fractionated with low $\mathrm{FeO}^{*} / \mathrm{MgO}$.

At such low grades of alteration, net gains and losses are probably relatively minor, since many mobile elements 
will be redistributed into stable secondary phases, such as clays, zeolites, and carbonates (cf. Wood et al., 1976; Floyd and Fuge, 1982). Elemental variation is essentially nonsystematic in Leg 89 basalts, and reflects not the overall alteration intensity, but more the development of specific secondary minerals, especially smectites.

\section{Secondary Mineral Distribution}

Secondary minerals are developed in the following locations in Leg 89 basalts: glass in quenched flow margins; interstitial glass in hypocrystalline units, phenocrysts, plagioclase-rich interiors of holocrystalline units, as infilling in vesicles, and as vein material in fractures. The distribution and composition of secondary minerals in both rock matrix and veins encountered on Leg 61 have been commented on by Kurnosov et al. (1981).

The quenched margins of both massive and thin flow units invariably show the development of yellow-brown palagonite and/or dark brown smectite between plumose variolites of clinopyroxene; fresh glass is generally not present. At the top of Unit 46, brown smectite is partially replaced by coarse green flakes of celadonite and carbonate, although this feature is rare, unless the marginal zone is fractured and traversed by vein material. Interstitial glass shows various alteration effects, and is always replaced by palagonite and/or smectite, the color of which may vary according to the absence or presence of magnetite granules and other crystallites. Glass, lacking associated late magnetite, is replaced by clear honeyyellow or lime-yellow palagonite, which may sometimes have a thin outer rim of replacing reddish-brown or brown smectite. In a few cases (e.g., Unit 48), dark brown smectite "vermicules" may be present in palagonite, suggesting diffusive replacement via crude perlitic cracks in the original glass. Palagonite containing magnetite is generally dark yellow-brown throughout and more granular in appearance. Some interstitial glass is totally replaced by dark brown, almost opaque smectite that often masks the presence of numerous magnetite granules.

Of the three phenocryst phases-olivine, palgioclase, and clinopyroxene-olivine is always completely replaced and plagioclase may be variably altered, especially in the crystal core, whereas clinopyroxene is always fresh. Olivine microphenocrysts in the interiors of the more massive units are completely pseudomorphed by greenish brown or dark brown smectite. Greater variation is seen in quenched flow margins, where olivine phenocrysts display crisscrossing veined microfractures set in a dirty green or brown smectite "matrix." In other cases, olivine is replaced by a dark red or reddish brown smectite, which may itself be partially replaced either by calcite or, more rarely, by a dark green celadonite. Only in the quenched margins of Unit 48 is olivine totally replaced by zeolite and calcite; this probably represents a further stage of alteration after initial pseudomorphing by smectite. Zoned plagioclase phenocrysts have cores replaced by dark brown or green pleochroic smectite or, more rarely, by bright green celadonite and calcite. Celadonite may be intermixed or may grade into any associated brown smectite, but is always itself replaced by calcite when present. Plagioclase microlites in quench zones may also be partially replaced by greenish smectite.
The interiors of flow units are relatively fresh, except for palagonitization of interstitial glass, pseudomorphing of any olivine microphenocrysts, and the intimate association of dark to opaque smectitic material blanketing coarse magnetite grains. However, the coarse-grained interiors of the more massive aphyric Units 48 and 52 show the patchy development of plagioclase alteration domains, with the variable growth of smectites, celadonite, zeolites, albite, and K-feldspar. This type of alteration is heralded by the development of acicular zeolite needles and the random development of minor green-brown smectite in plagioclase laths. Some crystals may eventually become almost totally replaced by smectite crowded with both acicular and feathery zeolites. A further development is the irregular replacement of plagioclase laths by anhedral pools of $\mathrm{K}$-feldspar (and albite) in areas rich in smectite. Extensive smectite development obscures plagioclase crystal boundaries, and often exhibits an apparent coaxial intergrowth of brown to opaque smectite fibers and dark green platy celadonite or smectite.

Although vesicles and/or vugs are generally lacking in the Leg 89 basalts, these features are considered to be represented, respectively, by ovoid areas, $0.2-0.3 \mathrm{~mm}$ in diameter, and larger, more irregular star-shaped regions. The amygdales are filled with a greenish smectite, or, when zoned, are lined with brown smectite and have a core of dark green smectite or celadonite. Vugs are present in Unit 55, and show the development of strongly pleochroic (yellow-green-greenish brown), radiate, coarsegrained plates of smectite.

Vein material has not been studied in detail, but the presence of ubiquitous pyrite in fractures throughout the lavas clearly indicates that reducing conditions were maintained during the later stages of alteration. Typical vein assemblages include pyrite-dark green smectite, smectitezeolites, smectite-zeolites-calcite, stilbite, stilbite-quartz. Zeolites are predominantly stilbite with minor phillipsite and heulandite. Higher in the flow sequence (drilled during Leg 61), zeolite-bearing quartz-poor, quartz-pyriterich, and quartz-celadonite assemblages were identified with increasing stratigraphic height (Windom and Book, 1981). Two vein-forming episodes were also recognized, with an initial reductive phase overprinted by a later oxidative phase which oxidized pyrite and smectite to $\mathrm{Fe}$ oxides and celadonite, respectively.

\section{Alteration Relative to Depth and Physical Parameters}

Variation of various physical and alteration parameters with depth is shown in Figure 6. The relative uniformity of these parameters indicates that there are no systematic trends in the intensity or character of alteration with depth. The major deviations occur at recognized volcanic unit boundaries, especially between Units 45 and 46 , where the base and top are defined by sharp increases in $\mathrm{H}_{2} \mathrm{O}^{+}, \mathrm{Fe}_{2} \mathrm{O}_{3} / \mathrm{FeO}$, and $\mathrm{CO}_{2}$, coupled with a decrease in basalt specific gravity. Some individual holocrystalline units show a "sawtooth" variation in the $\mathrm{Fe}_{2} \mathrm{O}_{3}$ / $\mathrm{FeO}$ ratio, which, considering the increase in oxidation at flow tops and bottoms, probably reflects the presence of thin multiple flow units rapidly produced during one eruptive event. Rapid extrusion throughout the eruptive event is also indicated by the constancy of the magnetic 


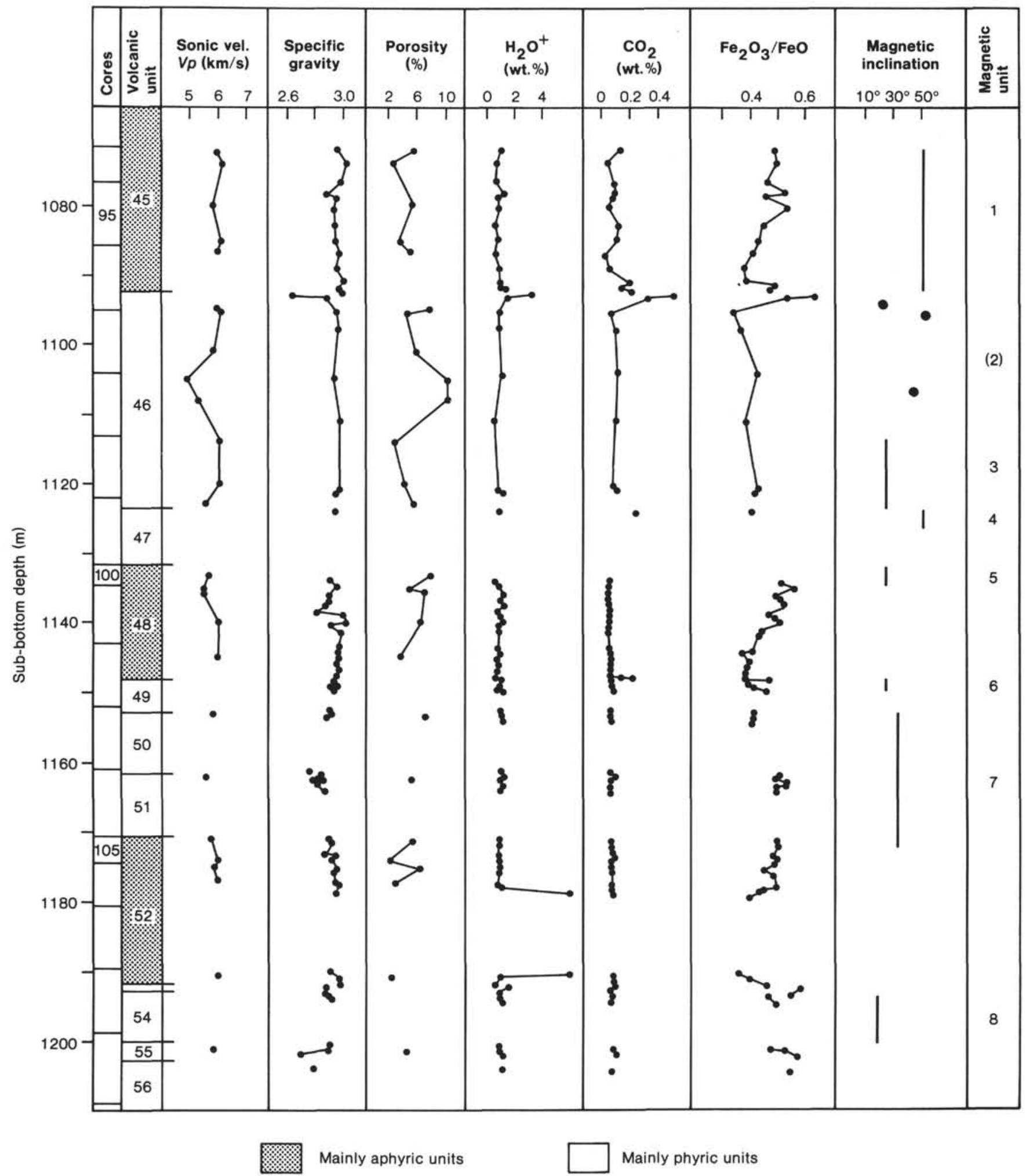

Figure 6. Variation of physical and alteration parameters with depth, Hole 462A. Parentheses in Magnetic unit column indicate that 2 is not strictly a single unit because of variations.

inclination for the volcanic unit. In areas where fracture-propogated alteration is minimal, marked decreases in specific gravity (and sonic velocity), caused by the presence of low-density secondary minerals, can also be used to distinguish internal boundaries.

\section{Summary and Conclusions}

1. Mineralogically and chemically, the alteration is mild throughout the lava pile and typical of low-temperature, post-consolidation reaction with seawater. 
2. Secondary mineral phases are dominated by various smectites in both the rock matrix and fractures, whereas pyrite is characteristically developed in fractures rather than the rock host. Secondary assemblages indicate low zeolite-facies alteration under reducing, acid to neutral, conditions. A late, well-developed oxidative phase with attendant extensive carbonation, as often seen in altered ocean-floor basalts, is not recorded in the Leg 89 lavas.

3. Two alteration stages are recognized. (a) Initial nonoxidative reactions involve palagonitization of glass, development of brownish smectite after palagonite, olivine, and plagioclase, and the (?) production of minor zeolites. The main chemical changes resulted in bulkrock increases in $\mathrm{H}_{2} \mathrm{O}^{+}$, mobility of $\mathrm{K}, \mathrm{Rb}, \mathrm{Ba}, \mathrm{Sr}$, and $\mathrm{Ni}$, and disturbance of the $\mathrm{FeO}^{*} / \mathrm{MgO}$ ratio. (b) $\mathrm{A}$ minor increase in redox potential followed, with the development of green smectite, celadonite, and calcite often replacing earlier phases; host-rock zeolites and K-feldspar may also have developed at, or just before, this stage. The second stage resulted in increases in $\mathrm{H}_{2} \mathrm{O}^{+}$, $\mathrm{Fe}_{2} \mathrm{O}_{3} / \mathrm{FeO}, \mathrm{CO}_{2}, \mathrm{~K}, \mathrm{Rb}$, and mobility of $\mathrm{Ca}$. That the conditions were still essentially reducing is illustrated by the development of pyrite-green smectite in fractures that traverse the whole lava pile.

4. No systematic changes in alteration intensity are recorded with depth. In the absence of extensive penetrative alteration adjacent to fractures, increases in $\mathrm{H}_{2} \mathrm{O}^{+}$, $\mathrm{Fe}_{2} \mathrm{O}_{3} / \mathrm{FeO}$, and $\mathrm{CO}_{2}$, coupled with decreases in specific gravity and sonic velocity, are representative of flow boundaries. Marked random increases in $\mathrm{K}$ or $\mathrm{K} / \mathrm{Rb}$ ratios reflect plagioclase alteration domains within massive flow units.

\section{PETROGRAPHY OF BASALTIC ROCKS}

Three basaltic types occur in the sheet flows. They are aphyric basalts, aphyric microdolerites, and sparsely to moderately phyric basalts, characterized by the following common phenocryst assemblages: clinopyroxeneplagioclase-olivine, clinopyroxene-plagioclase, and clinopyroxene-olivine \pm minor plagioclase. Phyric basalts (with $>10 \%$ total phenocrysts) are very limited in extent, and generally exhibit clinopyroxene-plagioclase-olivine phenocryst assemblages dominated by clinopyroxene. Basalts containing clinopyroxene and plagioclase phenocrysts are present throughout the total depth, whereas those containing olivine as a phenocryst phase appear to be concentrated in the upper stratigraphic units. Aphyric basalts constitute about $44 \%$ of the total lava pile, and form Volcanic Units 45, 48, and 52 (Fig. 2). Microdolerite occurs only in the coarse-grained interior of aphyric Unit 52.

Modal proportions based on point-count data for a number of samples are shown in Table 4. Clinopyroxene is the dominant phase in the matrix and among the phenocryst assemblages, whereas olivine has not been found in the matrix (unless masked by alteration products) and occurs only as individual microphenocrysts now replaced by smectite. Magnetite is common in all basalts, and in some cases reaches $10 \mathrm{vol} . \%$ of the rock. It is invariably a late crystallization product, associated with interstitial glass. Pyrite is secondary, and develops only in the host rock near to pyrite-smectite-filled fractures. Electron microprobe data on some of the primary phases are presented by Floyd and Rowbotham (this volume).

\section{Aphyric Basalts and Microdolerites}

In the central portions of flows, these rocks are olivine-free and either hypocrystalline or holocrystalline with granular to intersertal textures. Any interstitial glass is now palagonite or smectite, commonly crowded with magnetite granules or dendrites, or occasionally with plagioclase microlites. Polysynthetic twinned plagioclase laths form a groundmass lattice within which are dispersed anhedral clinopyroxene grains that crystallized later. In coarser holocrystalline varieties, large magnetite grains partly mantle pyroxene and plagioclase crystals. Some flow interiors, including the microdolerites, exhibit crystal habits indicative of quenching at relatively slow rates, with variolitic groups of wedge-shaped, serrated plagioclase subophitically enclosed in a central clinopyroxene nucleus. Individual plagioclase crystals often form long (up to $1.5 \mathrm{~mm}$ ) serrated curved crystals, or may be associated together in single or double pairs to form "bowties" (up to $2.5 \mathrm{~mm}$ across) unrelated to clinopyroxene. Irrespective of whether a flow interior exhibits quenchserrated plagioclase or well-crystallized subhedral laths, the clinopyroxene habit is invariably anhedral. In the central portion of Unit 48, however, clinopyroxene may occasionally develop as elongate serrated crystals which are nearly always twinned.

Quenched flow margins are nonvesicular, have hyalopilitic, variolitic, and, more rarely, spherulitic textures, with numerous crystallites and microlites of clinopyroxene, plagioclase, and magnetite set in altered glass. Because the proportion of crystalline material is always high and completely vitreous margins are generally lacking, flow tops were probably insulated by subsequent flows or glassy rubble removed by the next extrusion. A traverse from the outer glassy portion toward the more crystalline interior of a flow margin shows a number of morphological changes in the crystalline phases, as well as a decrease in the proportion of glass. Within the glassdominated outer portion, dark, variably coalesced clinopyroxene spherulites that have nucleated on tuningfork plagioclase microlites are developed. The dark color results partly from the fine grain-size of the clinopyroxene crystallites, and from the presence of minute interspersed $\mathrm{Fe}$ ore grains. Farther from the margin, dark clinopyroxene variolites may form the bulk of the matrix, enclosing glass and magnetite granules between splayed crystallites. Plagioclase typically forms swallow-tail or tuning-fork microlites that either form nuclei to the variolites or are randomly enclosed by them. Next, the grain size becomes coarser and the clinopyroxene more birefringent. Quenched clinopyroxene exhibits curved plumose sprays and sheaflike bundles either originating from a point growth-source or nucleated on larger existing clinopyroxene grains (microphenocrysts). Magnetite grains are concentrated on the margins of the variolites, rather than within them. Plagioclase, which always appears to have crystallized first, maintains a microlitic form, and 
Table 4. Modal proportions of primary and secondary minerals in selected basalts, Hole $462 \mathrm{~A}$.

\begin{tabular}{|c|c|c|c|c|c|c|c|c|c|c|c|c|c|}
\hline \multirow{2}{*}{$\begin{array}{c}\text { Keele } \\
\text { number }\end{array}$} & \multirow{2}{*}{$\begin{array}{l}\text { Points } \\
\text { counted }\end{array}$} & \multicolumn{3}{|c|}{ Phenocrysts } & \multicolumn{4}{|c|}{ Matrix } & \multicolumn{4}{|c|}{ Alteration } & \multirow[b]{2}{*}{ Comments on alteration features } \\
\hline & & $\mathrm{cpx}$ & plag & ol & $\mathrm{cpx}$ & plag & mag & pyrite & pal & smect & zeol & carb & \\
\hline $462 \mathrm{~A}-1$ & 2009 & 1.7 & 0.4 & a & 35.7 & 22.7 & 7.1 & & 2.0 & 30.2 & 0.1 & tr & Dark golden brown smectite replaces olivine microphenocrysts \\
\hline $462 \mathrm{~A}-4$ & 2059 & 0.4 & 1.4 & a & 38.0 & 24.3 & 7.9 & & 1.5 & 26.3 & 0.2 & & Opaquę smectitic material partly obscures magnetite \\
\hline $462 \mathrm{~A}-7$ & 2007 & 0.1 & 0.5 & a & 37.6 & 28.3 & 8.3 & & tr & 25.1 & 0.1 & & Ore closely associated with dark smectite-replaced interstitial glass \\
\hline $462 \mathrm{~A}-10$ & 2084 & & 1.6 & & 42.0 & 22.5 & 9.2 & & $\mathrm{tr}$ & 24.1 & 0.6 & & $\begin{array}{l}\text { Some dark smectite (montmorillonite?) partly replaces plagioclase } \\
\text { microphenocrysts }\end{array}$ \\
\hline $462 \mathrm{~A}-13$ & 2147 & 9.7 & 1.3 & & 58.4 & 13.2 & 8.6 & & tr & 8.5 & & 0.4 & Quench texture, larger granular cpx recorded as "phenocrysts" \\
\hline $462 \mathrm{~A}-15$ & 1965 & 20.3 & 0.3 & a & 25.1 & 18.7 & 10.9 & & 1.3 & 23.5 & & 0.2 & Quench texture, larger granular cpx recorded as "phenocrysts" \\
\hline $462 \mathrm{~A}-18$ & 1983 & & & & 39.8 & 27.5 & 9.2 & & 0.2 & 22.9 & 0.3 & & Zeolite fibers associated with brown smectite \\
\hline $462 \mathrm{~A}-20$ & 2061 & tr & 1.2 & $a_{\text {? }}$ & 41.1 & 25.8 & 9.1 & & 0.4 & 22.3 & & & Glomerocrystic plagioclase, some with $\mathrm{cpx}$ inclusion zones \\
\hline $462 \mathrm{~A}-21$ & 2065 & 10.6 & 2.7 & & 46.6 & 14.2 & 9.2 & & 13.7 & 3.1 & & & Quench texture, larger granular cpx recorded as "phenocrysts" \\
\hline $462 \mathrm{~A}-22$ & 1990 & 16.4 & 0.6 & $a_{\text {? }}$ & 29.4 & 11.8 & 9.6 & & 25.0 & 6.9 & & 0.4 & Cores of plagioclase microphenocrysts replaced by green smectite \\
\hline $462 \mathrm{~A}-23$ & 2179 & & tr & & 46.1 & 19.8 & 8.9 & & 1.2 & 24.1 & & & Magnetite partly obscured by opaque smectite \\
\hline $462 \mathrm{~A}-27$ & 2027 & & tr & & 38.8 & 33.7 & 4.6 & & tr & 22.9 & & & Granular crystallites in smectite-replaced interstitial glass \\
\hline $462 \mathrm{~A}-31$ & 2159 & & & & 40.6 & 31.9 & 8.3 & 0.6 & $\mathrm{tr}$ & 16.6 & 2.0 & & Rare islets of golden palagonite in yellow-brown smectite \\
\hline 462A-34 & 2020 & & & & 40.1 & 33.6 & 3.7 & & tr & 21.0 & 1.6 & & Zeolite needles in plagioclase \\
\hline 462A-38 & 2055 & & & & 45.5 & 27.0 & 3.2 & & 3.0 & 20.0 & 1.3 & & Magnetite partly obscured by opaque smectite \\
\hline $462 \mathrm{~A}-40$ & 2021 & 2.7 & 2.0 & a & 51.1 & 22.1 & 4.4 & 0.4 & 3.8 & 13.4 & & 0.2 & $\begin{array}{l}\text { Olivine microphenocrysts replaced by yellow-brown smectite and } \\
\text { minor carbonate }\end{array}$ \\
\hline $462 \mathrm{~A}-41$ & 1093 & 2.4 & 3.4 & a & 76.0 & 3.3 & 9.7 & & & 1.6 & 3.1 & 0.5 & Matrix cpx also includes altered glass between plumose crystallites \\
\hline $462 \mathrm{~A}-43$ & 1994 & 1.0 & 0.4 & a & 50.5 & 16.9 & 9.9 & & 13.0 & 8.3 & & & Dark golden-brown smectite replaces olivine microphenocrysts \\
\hline $462 \mathrm{~A}-46$ & 2104 & 2.9 & 1.5 & & 49.8 & 17.6 & 13.5 & & 8.3 & 6.5 & & & Pale yellow-brown palagonite and smectite replace interstitial glass \\
\hline $462 \mathrm{~A}-48$ & 2041 & 2.6 & 2.2 & & 50.8 & 23.3 & 7.5 & & 8.6 & 5.0 & & & Brown smectite rims pale greenish yellow palagonite areas \\
\hline $462 \mathrm{~A}-51$ & 1065 & 2.9 & 3.0 & a & 71.5 & 10.8 & 10.1 & & & 1.8 & & & $\begin{array}{l}\text { Matrix cpx also includes glass between crystallites; smectite } \\
\text { replaces olivine }\end{array}$ \\
\hline $462 \mathrm{~A}-52$ & 2033 & 0.9 & 1.1 & a & 58.6 & 17.2 & 6.0 & & 11.7 & 4.4 & & & Lime-green smectite replaces olivine(?) phenocrysts \\
\hline $462 \mathrm{~A}-54$ & 2008 & 2.3 & 1.6 & & 56.8 & 12.9 & 4.9 & & 14.9 & 6.5 & & & $\begin{array}{l}\text { Plagioclase phenocrysts partly replaced by green smectite and rare } \\
\text { analcite }\end{array}$ \\
\hline $462 \mathrm{~A}-55$ & 2038 & 2.9 & 2.1 & & 42.9 & 21.2 & 10.1 & & 18.8 & 2.0 & & & Yellow smectite replaces interstitial glass \\
\hline $462 \mathrm{~A}-56$ & 2018 & 0.2 & 0.7 & & 41.6 & 28.5 & 7.9 & & 16.2 & 4.8 & & & Palagonitized interstitial glass crowded with crystallites \\
\hline $462 \mathrm{~A}-61$ & 2044 & & & & 43.7 & 31.9 & 7.6 & & & 14.3 & 2.4 & & Zeolite needles and blue-green celadonite in plagioclase laths \\
\hline $462 \mathrm{~A}-63$ & 1516 & & & & 38.1 & 35.8 & 6.5 & & & 19.1 & 0.6 & & $\begin{array}{l}\text { Bright green celadonite ( } 1 \% \text { of smectite) and late } \mathrm{K} \text {-feldspars } \\
\text { replace plagioclase }\end{array}$ \\
\hline $462 \mathrm{~A}-66$ & 2019 & & & & 40.7 & 38.3 & 7.9 & & tr & 11.3 & 1.8 & & Opaque smectite associated with magnetite and $\mathrm{cpx}$ rims \\
\hline $462 \mathrm{~A}-69$ & 1877 & 0.5 & 0.4 & & 42.0 & 21.9 & 11.4 & & 17.8 & 5.9 & & & Recorded smectite largely replacing plagioclase phenocrysts \\
\hline $462 \mathrm{~A}-71$ & 1703 & 4.2 & 0.4 & & 43.9 & 18.3 & 9.2 & & 3.2 & 20.9 & & & $\begin{array}{l}\text { Greenish smectite replaces plagioclase phenocrysts; brown smectite } \\
\text { replaces glass }\end{array}$ \\
\hline $462 \mathrm{~A}-73$ & 2012 & 0.9 & 0.7 & & 40.7 & 33.2 & 7.7 & & 12.9 & 3.9 & & tr & Granular brownish smectite replaces interstitial glass \\
\hline $462 \mathrm{~A}-75$ & 1992 & 4.9 & 2.7 & & 40.8 & 17.6 & 10.1 & & 17.6 & 6.4 & & & $\begin{array}{l}\text { Green smectite or celadonite flakes replace plagioclase microphe- } \\
\text { nocrysts }\end{array}$ \\
\hline
\end{tabular}

Note: $\mathrm{cpx}=$ clinopyroxene; plag = plagioclase; ol = olivine; mag = magnetite; pal = palagonite; smect = smectite; zeol = zeolite; carb = carbonate; $\mathrm{tr}=\mathrm{trace}(<0.1 \mathrm{modal} \%)$. ${ }^{a}$ Present originally, but now totally replaced.

does not develop larger skeletal crystals with serrated edges until well inside the flow. All the features described are clearly related to the rate of cooling of the flow, and are characteristic of many mid-ocean ridge (MOR) pillow basalts (e.g., Kirkpatrick, 1979; Natland, 1979a).

A common variant occurs in which the flow margins of some essentially aphyric basalt units are to some degree porphyritic, with large zoned plagioclases, loosely clumped groups of anhedral clinopyroxene crystals, and sometimes small smectite-replaced ovoids of olivine. Glomerocrystic groups of clinopyroxene and plagioclase are also relatively common.

\section{Variably Phyric Basalts}

Flows composed of variably phyric basalts may have quenched glassy margins and hypocrystalline or holocrystalline interiors, whereas others are quench-textured throughout (e.g., Units 49-51) and show matrix textures and mineralogy similar to those of the aphyric flows already described. Some units are poorly vesicular with smectite-filled vesicles ( $\sim 0.2 \mathrm{~mm}$ diameter). The granular groundmass of flow interiors is composed of small crystals of clinopyroxene $(0.05-0.10 \mathrm{~mm})$, plagioclase
(0.1-0.2 mm), and magnetite $(0.01-0.05 \mathrm{~mm})$. Again, some interiors exhibit coarse quench textures, showing not only serrated skeletal plagioclase but also variolites composed of both individual plagioclase and clinopyroxene bowties. In a few cases, plagioclase and clinopyroxene may form intimate coaxial intergrowths in the bowtie. Glassy margins are again variolitic and characterized by plumose clinopyroxene (typically up to $0.2 \mathrm{~mm}$ long), often peppered with magnetite grains, together with scattered forked or lath-shaped plagioclase microlites. Farther from the flow margin, some clinopyroxene plumes may be $0.4-0.5 \mathrm{~mm}$ long, and the sheaflike bundles are up to $1.0 \mathrm{~mm}$ long.

Olivine microphenocrysts $(0.2-0.4 \mathrm{~mm})$ are always replaced by smectite, and tend to be euhedral in quenched margins but more irregular and embayed(?) in flow interiors. Plagioclase phenocrysts $\left(\mathrm{An}_{70-80}\right)$ are invariably Carlsbad twinned, sometimes polysynthetic twinned, and generally lath-shaped $(0.2-0.5 \mathrm{~mm})$ if present as isolated crystals. Some individuals are faintly zoned with cores replaced by greenish smectite. Hypocrystalline rocks may show a mixture of plagioclase morphologies, with forked microlites and variable sizes of serrated wedges and laths 
that grade up to a few subhedral crystals of phenocryst size. The gradation in size suggests that plagioclase crystallization may have been continuous throughout preeruptive history and final quenching on the ocean floor. Clinopyroxene phenocrysts $(\sim 0.2 \mathrm{~mm})$ typically form granular-textured glomerocrystic groups up to $1 \mathrm{~mm}$ across. Plagioclase may be associated with these groups, although the texture remains granular, and only rarely is it enclosed subophitically. In a manner similar to plagioclase, clinopyroxene may display a number of grain sizes in the same rock, with glomerocrysts composed of small grains and larger subhedral individual phenocrysts all set in a fine-grained hyalopilitic groundmass of quenched clinopyroxene plumes.

\section{CHEMICAL VARIATION AND PETROGENESIS}

A series of 75 basalt samples from Leg 89 was chemically analyzed (1) to identify the geochemical features of intraplate submarine sheet-flows, and (2) to determine any coherent chemical groups and their petrogenetic relationships. Major- and trace-element data for the basalts are presented in Table 5, and the corresponding DSDP sample number, sub-bottom depth, and a brief lithology of each sample are given in Table 1. Normative data are listed in Table 6.

\section{Normative and General Chemical Characteristics}

The basalts are all hypersthene- (hy) and diopside(di) rich, and as illustrated by the spread in the basalt trapezohedron (Fig. 7), are exclusively olivine- (ol) or quartz- (qz) normative tholeiites. The phyric basalts (Volcanic Units 46, 47, 49-51, and 53-56) are all ol-normative, as are the few aphyric basalts within Unit 46 , whereas the aphyric basalts of Units 48 and 52 are qz-normative. This appears to be a real difference and not an oxidation effect, since all data were normalized to an oxidation ratio of 0.15 before calculation. Oceanic basalts and glasses from the Mid-Atlantic Ridge (MAR) and East Pacific Rise (EPR) show a similar spread across the silica saturation divide (e.g., Flower et al., 1977; Tarney et al., 1979; Humphris, Thompson, Gibson, et al., 1980), although many are strictly ol-normative (Fig. 7). Relative to low-pressure experimental equilibria (Thompson, 1982), the Leg 89 basalts form a trend parallel to the 1-atm. cotectic in equilibrium with olivine-plagioclase-pyroxene (Fig. 7), but are displaced towards hy. Thompson et al. (1983) suggest that one possible explanation for the displacement may be that originally deep-seated magma ponded in short-lived, high-level magma chambers and did not have enough time during residence to crystallize to the 1-atm. cotectic. Possible support for this suggestion in the Leg 89 lavas is the total lack of cumulates, the presence of at least two generations of clinopyroxene and plagioclase phenocrysts, and often complete chemical overlap between phyric and aphyric units, implying minimal fractionation.

Chemically the basalts are characterized by the following features (Table 5 and 7):

1. They are tholeiites with relatively uniform compositions throughout (as exhibited by the small elemental range), compared with the variable chemical composition in many ocean basalt sequences.
2. Limited internal differentiation (resulting from different magma groups and/or magmatic processes) is suggested, however, by variable $\mathrm{FeO}^{*} / \mathrm{MgO}$ ratios (1.6-2.1) and antipathetic relationships between compatible and incompatible elements within some volcanic units.

3. As a group, the majority of basalts have a high $\mathrm{FeO}^{*}$ content $(>12 \mathrm{wt} . \%)$ similar to that of some oceanic ferrobasalts (e.g., Galapagos Rift; Natland, 1980), although incompatible-element abundances are generally lower.

4. Incompatible elements, especially $\mathrm{La}, \mathrm{Ce}, \mathrm{U}, \mathrm{Th}$, $\mathrm{K}, \mathrm{Rb}, \mathrm{Ba}, \mathrm{Hf}, \mathrm{Nb}$, and $\mathrm{Y}$, have low abundances, although marginally higher than N-type MORB. The wide range shown by $\mathrm{K}, \mathrm{Rb}, \mathrm{Ba}$, and possibly $\mathrm{U}$ is a reflection of mobility during mild alteration.

5. On average, siderophile-element contents are relatively low and indicate moderately evolved compositions compared with primary basaltic melts having high $\mathrm{MgO}$ of $10-13 \mathrm{wt} . \%$ and Ni contents of about $300-400 \mathrm{ppm}$ (Sato, 1977; Hart and Davis, 1978).

6. Chondrite-normalized $\mathrm{Ce} / \mathrm{Y}$ ratios $(\sim 0.9)$ and $\mathrm{REE}$ data (Saunders, this volume) show that the basalts are light-REE-depleted, but to nowhere near the same extent as N-type MORB.

7. Ratios of many incompatible elements with similar, low distribution coefficients $\left(\mathrm{K}_{D}\right.$ 's) (e.g., $\mathrm{Th} / \mathrm{U}, \mathrm{La} /$ $\mathrm{Nb}, \mathrm{Ti} / \mathrm{Zr}, \mathrm{Zr} / \mathrm{Nb}, \mathrm{Ti} / \mathrm{Y}, \mathrm{Zr} / \mathrm{Y}, \mathrm{TiO}_{2} / \mathrm{P}_{2} \mathrm{O}_{5}$ ) have generally lower than chondritic values, although $\mathrm{TiO}_{2} / \mathrm{P}_{2} \mathrm{O}_{5}$ is higher (Table 7).

The type B flow basalts of Leg 61 (Batiza, 1981) also exhibit chemical uniformity, selectively depleted incompatible-element compositions, and an overall dissimilarity to N-type MORB. Although some degree of downhole variation (e.g., increasing $\mathrm{TiO}_{2}$ ) was apparent during Leg 61, no specific chemical groups were documented. Saunders (this volume), on the basis of variable $\mathrm{Zr}$ content (Legs 61 and 89, new data), has demonstrated the presence of three chemical groups developed sequentially downhole: I (upper sils), and II and III (lower sheetflows); all the Leg 89 section falls in group III. In general terms, the basalts in the basal section of the hole (sampled during Leg 89) are more evolved than those higher up (sampled during Leg 61), and have higher $\mathrm{Zr}$ and lower Ni contents (Saunders, this volume) and, as seen from the distributions in Figure 8, higher $\mathrm{TiO}_{2}, \mathrm{~K}_{2} \mathrm{O}$, $\mathrm{FeO}^{*}$, and $\mathrm{FeO}^{*} / \mathrm{MgO}$ ratios.

\section{Chemical Stratigraphy}

Downhole chemical variations for selected elements and ratios are shown in Figure 9. Although minor fluctuations are evident within the small elemental range exhibited, some generalized trends with depth are observed: (1) The $\mathrm{FeO} * / \mathrm{MgO}$ ratio increases and $\mathrm{Cr}$ and $\mathrm{Ni}$ decrease, whereas (2) $\mathrm{Zr}, \mathrm{Y}, \mathrm{La}, \mathrm{Ce}, \mathrm{Nd}$, and $\mathrm{Sr}$ increase. Although the crude antipathetic relationship between compatible and incompatible elements could imply that the basalt pile represents the products of a single fractionated magma chamber, the generalized trends are to some extent influenced by the relatively high incompatible-element contents of volcanic units at the base of the sequence. Also, the trends are not completely systematic for all related elements; for example, compatible Sc in- 
Table 5. Major- (wt.\%) and trace- (ppm) element data on Nauru Basin basaltic lava flows, Hole 462A, by Keele numbers.

\begin{tabular}{|c|c|c|c|c|c|c|c|c|c|c|c|c|c|c|c|c|}
\hline & $462 \mathrm{~A}-1$ & $462 \mathrm{~A}-2$ & $462 \mathrm{~A}-3$ & $462 \mathrm{~A}-4$ & $462 \mathrm{~A}-5$ & $462 \mathrm{~A}-6$ & $462 \mathrm{~A}-7$ & $462 \mathrm{~A}-8$ & $462 \mathrm{~A}-9$ & $462 \mathrm{~A} \cdot 10$ & $462 \mathrm{~A}-11$ & $462 \mathrm{~A}-12$ & $462 \mathrm{~A}-13$ & $462 \mathrm{~A}-14$ & $462 \mathrm{~A}-15$ & $462 \mathrm{~A}-16$ \\
\hline $\mathrm{SiO}_{2}$ & 48.97 & 50.39 & 50.72 & 49.76 & 49.61 & 50.11 & 50.72 & 50.03 & 50.51 & 49.47 & 50.04 & 50.19 & 49.42 & 49.16 & 50.24 & 50.29 \\
\hline $\mathrm{TiO}_{2}$ & 1.33 & 1.27 & 1.31 & 1.29 & 1.33 & 1.31 & 1.28 & 1.28 & 1.27 & 1.32 & 1.23 & 1.31 & 1.31 & 1.23 & 1.32 & 1.26 \\
\hline $\mathrm{Al}_{2} \mathrm{O}_{3}$ & 14.51 & 13.99 & 13.82 & 14.05 & 14.06 & 14.23 & 13.97 & 13.61 & 13.59 & 14.27 & 13.68 & 14.03 & 13.83 & 13.69 & 14.22 & 13.87 \\
\hline $\mathrm{Fe}_{2} \mathrm{O}_{3}$ & 4.26 & 4.43 & 4.19 & 4.33 & 4.28 & 4.50 & 4.00 & 3.95 & 3.87 & 3.57 & $\begin{array}{r}3.50 \\
3.59\end{array}$ & 4.38 & 4.11 & 6.60 & 4.23 & 3.25 \\
\hline $\mathrm{FeO}$ & 8.72 & 8.92 & 9.12 & 8.11 & 9.34 & 8.47 & 9.03 & 9.20 & 9.55 & 9.38 & 9.57 & 9.11 & 8.67 & 6.74 & 8.14 & 9.70 \\
\hline $\mathrm{MnO}$ & 0.22 & 0.20 & 0.20 & 0.19 & 0.23 & 0.20 & 0.20 & 0.22 & 0.22 & 0.22 & 0.22 & 0.22 & 0.22 & 0.14 & 0.26 & 0.20 \\
\hline $\mathrm{MgO}$ & 6.76 & 6.24 & 6.73 & 6.81 & 7.15 & 6.75 & 6.68 & 7.00 & 6.96 & 6.93 & 7.12 & 7.08 & 7.02 & 7.82 & 6.74 & 6.82 \\
\hline $\mathrm{CaO}$ & 11.92 & 11.33 & 11.34 & 11.72 & 11.80 & 11.61 & 11.65 & 11.17 & 11.35 & 11.76 & 10.84 & 10.51 & 11.57 & 9.02 & 11.37 & 11.34 \\
\hline $\mathrm{Na}_{2} \mathrm{O}$ & 2.55 & 2.45 & 2.49 & 2.48 & 2.34 & 2.45 & 2.40 & 2.38 & 2.54 & 2.44 & $\begin{array}{r}10.04 \\
2.30\end{array}$ & 2.41 & 2.43 & 1.81 & 2.73 & 2.51 \\
\hline $\mathrm{K}_{2} \mathrm{O}$ & 0.13 & 0.14 & 0.14 & 0.15 & 0.12 & 0.13 & 0.12 & 0.12 & 0.15 & 0.13 & 0.32 & 0.12 & 0.12 & 0.16 & 0.12 & 0.13 \\
\hline $\mathrm{P}_{2} \mathrm{O}_{5}$ & 0.11 & 0.11 & 0.11 & 0.10 & 0.11 & 0.11 & 0.11 & 0.10 & 0.10 & 0.11 & 0.11 & 0.11 & 0.10 & 0.09 & 0.11 & 0.11 \\
\hline $\mathrm{H}_{2} \mathrm{O}^{+}$ & 0.97 & 0.76 & 0.65 & 1.07 & 0.83 & 0.84 & 0.65 & 0.81 & 0.64 & 0.84 & 0.98 & 0.94 & 1.26 & 3.06 & 1.05 & 0.76 \\
\hline $\mathrm{CO}_{2}$ & 0.13 & 0.04 & 0.08 & 0.08 & 0.07 & 0.04 & 0.11 & 0.10 & 0.02 & 0.04 & 0.20 & 0.12 & 0.19 & 0.51 & 0.31 & 0.04 \\
\hline Total & 100.58 & 100.27 & 100.90 & 100.14 & 101.27 & 100.75 & 100.92 & 99.98 & 100.77 & 100.48 & 100.20 & 100.53 & 100.35 & 100.03 & 100.84 & 100.28 \\
\hline S.G. ${ }^{a}$ & 2.95 & 3.10 & 2.97 & 2.88 & 2.94 & 2.93 & 2.94 & 2.94 & 2.97 & 2.95 & 2.99 & 2.96 & 2.97 & 2.63 & 2.87 & 2.95 \\
\hline $\mathrm{FeO} * / \mathrm{MgO}$ & 1.86 & 2.07 & 1.92 & 1.76 & 1.85 & 1.85 & 1.89 & 1.82 & 1.87 & 1.82 & 1.80 & 1.84 & 1.76 & 1.62 & 1.77 & 1.85 \\
\hline $\mathrm{Fe}_{2} \mathrm{O}_{3} / \mathrm{FeO}$ & 0.49 & 0.50 & 0.46 & 0.53 & 0.46 & 0.53 & 0.44 & 0.43 & 0.41 & 0.35 & 0.38 & 0.48 & 0.47 & 0.98 & 0.52 & 0.34 \\
\hline $\mathrm{Ba}$ & 8 & 5 & 22 & 39 & 15 & 10 & 10 & 14 & 5 & 14 & 10 & 5 & 11 & 27 & 32 & 28 \\
\hline $\mathrm{Ce}$ & 13 & 11 & 11 & 10 & 10 & 11 & is & 10 & 16 & 14 & 16 & 14 & 14 & 15 & 14 & 16 \\
\hline $\mathrm{Cr}$ & 159 & 159 & 154 & 169 & 166 & 160 & 164 & 162 & 165 & 166 & 163 & 159 & 162 & 179 & 163 & 158 \\
\hline La & 6 & 4 & 5 & 4 & 4 & 4 & 6 & 4 & 5 & 5 & 6 & 5 & 5 & 5 & 5 & 6 \\
\hline $\mathrm{Nb}$ & 6 & 6 & 6 & 6 & 6 & 8 & 6 & 5 & 6 & 6 & 5 & 4 & 6 & 6 & 5 & 5 \\
\hline $\mathrm{Nd}$ & 11 & 10 & 11 & 7 & 7 & 10 & 10 & 11 & 12 & 8 & 11 & 9 & 9 & 9 & 8 & 10 \\
\hline $\mathrm{Ni}$ & 85 & 81 & 81 & 84 & 85 & 86 & 88 & 88 & 88 & $85^{\circ}$ & 85 & 87 & 88 & 88 & 91 & 84 \\
\hline $\mathrm{Rb}$ & 5 & 5 & 5 & 2 & 2 & 3 & 2 & 2 & 2 & 9 & 9 & 5 & 3 & 2 & 5 & 4 \\
\hline $\mathrm{Sc}$ & 43 & 43 & 40 & 44 & 43 & 44 & 42 & 41 & 42 & 41 & 42 & 43 & 44 & 48 & 48 & 42 \\
\hline Sr & 112 & 108 & 114 & 113 & 113 & 113 & 108 & 106 & 103 & 108 & 109 & 112 & 111 & 122 & 111 & 107 \\
\hline Y & 32 & 28 & 28 & 28 & 29 & 28 & 28 & 28 & 28 & 32 & 29 & 32 & 31 & 31 & 32 & 31 \\
\hline $\mathrm{Zr}$ & 71 & 67 & 71 & 62 & 65 & 66 & 63 & 67 & 69 & 60 & 58 & 61 & 62 & 59 & 64 & 61 \\
\hline $\mathrm{Hf}$ & & 1.74 & & 1.86 & & & 1.88 & & & 1.86 & & & 1.84 & & 1.95 & 1.93 \\
\hline $\mathrm{Ta}$ & & 0.40 & & 0.55 & & & 0.75 & & & 0,70 & & & 0.50 & & 0.67 & 0.70 \\
\hline Th & & 0.26 & & 0.26 & & & 0.26 & & & 0.27 & & & 0.28 & & 0.27 & 0.27 \\
\hline U & & 0.06 & & 0.07 & & & 0.06 & & & 0.058 & & & 0.07 & & 0.08 & 0.051 \\
\hline
\end{tabular}

a S.G. = specific gravity.

Table 5. (continued).

\begin{tabular}{|c|c|c|c|c|c|c|c|c|c|c|c|c|c|c|c|}
\hline & $462 A-33$ & $462 A-34$ & $462 A-35$ & $462 A-36$ & $462 A-37$ & $462 A-38$ & $462 A-39$ & $462 \mathrm{~A}-40$ & $462 \mathrm{~A}-41$ & $462 A-42$ & $462 \mathrm{~A}-43$ & $462 \mathrm{~A}-44$ & $462 \mathrm{~A}-45$ & $462 \mathrm{~A}-46$ & $462 A-47$ \\
\hline $\mathrm{SiO}_{2}$ & 51.12 & 50.55 & 50.19 & 51.52 & 50.63 & 50.84 & 50.95 & 50.88 & 50.18 & 50.18 & 49.52 & 49.98 & 49.67 & 49.88 & 49.88 \\
\hline $\mathrm{TiO}_{2}$ & 1.20 & 1.18 & 1.18 & 1.19 & 1.16 & 1.23 & 1.23 & 1.24 & 1.24 & 1.24 & 1.25 & 1.26 & 1.25 & 1.23 & 1.25 \\
\hline $\mathrm{Al}_{2} \mathrm{O}_{3}$ & 13.89 & 13.82 & 13.98 & 13.93 & 13.99 & 13.78 & 13.78 & 14.06 & 13.84 & 14.00 & 14.12 & 14.01 & 14.03 & 14.00 & 14.04 \\
\hline $\mathrm{Fe}_{2} \mathrm{O}_{3}$ & 3.78 & 3.37 & 3.63 & 3.52 & 3.71 & 3.55 & 3.54 & 4.04 & 3.48 & 3.53 & 4.20 & 3.88 & 4.24 & 3.88 & 3.82 \\
\hline $\mathrm{FeO}$ & 9.19 & 9.19 & 9.17 & 9.01 & 9.30 & 9.33 & 9.27 & 8.62 & 9.11 & 9.11 & 9.13 & 9.37 & 9.03 & 9.19 & 9.17 \\
\hline $\mathrm{MnO}$ & 0.20 & 0.20 & 0.20 & 0.20 & 0.20 & 0.20 & 0.20 & 0.20 & 0.20 & 0.23 & 0.23 & 0.25 & 0.23 & 0.23 & 0.25 \\
\hline $\mathrm{MgO}$ & 6.59 & 6.93 & 6.95 & 7.01 & 6.72 & 6.76 & 6.70 & 6.52 & 6.36 & 6.47 & 7.02 & 6.78 & 7.01 & 6.70 & 6.95 \\
\hline $\mathrm{CaO}$ & 11.49 & 11.38 & 11.45 & 11.46 & 11.31 & 11.39 & 11.52 & 11.40 & 11.22 & 11.38 & 11.64 & 11.79 & 11.89 & 11.68 & 11.66 \\
\hline $\mathrm{Na}_{2} \mathrm{O}$ & 2.31 & 2.28 & 2.34 & 2.34 & 2.41 & 2.40 & 2.42 & 2.35 & 2.34 & 2.37 & 2.37 & 2.30 & 2.45 & 2.39 & 2.36 \\
\hline $\mathrm{K}_{2} \mathrm{O}$ & 0.13 & 0.13 & 0.12 & 0.12 & 0.13 & 0.12 & 0.13 & 0.13 & 0.15 & 0.14 & 0.17 & 0.21 & 0.13 & 0.14 & 0.17 \\
\hline $\mathrm{P}_{2} \mathrm{O}_{5}$ & 0.10 & 0.10 & 0.10 & 0.10 & 0.10 & 0.11 & 0.10 & 0.10 & 0.11 & 0.10 & 0.10 & 0.11 & 0.10 & 0.11 & 0.11 \\
\hline $\mathrm{H}_{2} \mathrm{O}^{+}$ & 0.93 & 1.01 & 0.84 & 0.90 & 0.96 & 0.88 & 0.76 & 1.12 & 1.06 & 1.03 & 1.07 & 0.82 & 1.10 & 1.01 & 1.03 \\
\hline $\mathrm{CO}_{2}$ & 0.02 & 0.02 & 0.02 & 0.02 & 0.02 & 0.02 & 0.02 & 0.08 & 0.18 & 0.03 & 0.02 & 0.02 & 0.04 & 0.02 & 0.02 \\
\hline Total & 100.95 & 100.16 & 100.17 & 101.32 & 100.64 & 100.61 & 100.62 & 100.74 & 99.47 & 99.81 & 100.84 & 100.78 & 101.17 & 100.46 & 100.71 \\
\hline S.G. ${ }^{a}$ & 2.97 & 2.97 & 2.97 & 2.97 & 2.99 & 2.97 & 2.97 & 2.93 & 2.94 & 2.93 & 2.92 & 2.97 & 2.94 & 2.92 & 2.93 \\
\hline $\mathrm{FeO} / \mathrm{MgO}$ & 1.91 & 1.76 & 1.79 & 1.74 & 1.88 & 1.85 & 1.86 & 1.88 & 1.92 & 1.90 & 1.84 & 1.90 & 1.83 & 1.89 & 1.81 \\
\hline $\mathrm{Fe}_{2} \mathrm{O}_{3} / \mathrm{FeO}$ & 0.41 & 0.37 & 0.40 & 0.39 & 0.40 & 0.38 & 0.38 & 0.47 & 0.38 & 0.39 & 0.46 & 0.41 & 0.47 & 0.42 & 0.42 \\
\hline $\mathrm{Ba}$ & 5 & 5 & 26 & 15 & 12 & 33 & 15 & 44 & 24 & 17 & 5 & 9 & 6 & 5 & 5 \\
\hline $\mathrm{Ce}$ & 11 & 8 & 7 & 13 & 8 & 6 & 6 & 10 & 10 & 14 & 16 & 14 & 16 & 15 & 15 \\
\hline $\mathrm{Cr}$ & 159 & 164 & 163 & 160 & 153 & 152 & 150 & 151 & 141 & 142 & 138 & 138 & 139 & 137 & 142 \\
\hline La & 4 & 4 & 3 & 4 & 3 & 4 & 3 & 3 & 3 & 5 & 4 & 5 & 4 & 5 & 5 \\
\hline $\mathrm{Nb}$ & 6 & 5 & 6 & 4 & 6 & 5 & 6 & 5 & 5 & 5 & 5 & 5 & 5 & 4 & 5 \\
\hline Nd & 8 & 10 & 6 & 10 & 7 & 5 & 5 & 9 & 8 & 11 & 12 & 10 & 12 & 9 & 9 \\
\hline $\mathrm{Ni}$ & 83 & 84 & 87 & 85 & 87 & 88 & 84 & 83 & 80 & 81 & 76 & 74 & 75 & 77 & 83 \\
\hline $\mathrm{Rb}$ & 2 & 2 & 2 & 4 & 5 & 4 & 4 & 2 & 2 & 6 & 6 & 7 & 5 & 2 & 2 \\
\hline $\mathrm{Sc}$ & 45 & 44 & 43 & 44 & 46 & 46 & 46 & 46 & 48 & 48 & 48 & 45 & 45 & 47 & 48 \\
\hline $\mathrm{Sr}$ & 109 & 109 & 109 & 110 & 112 & 115 & 117 & 110 & 109 & 112 & 110 & 112 & 112 & 110 & 107 \\
\hline Y & 26 & 23 & 23 & 24 & 22 & 26 & 25 & 28 & 27 & 27 & 32 & 28 & 32 & 27 & 27 \\
\hline $\mathrm{Zr}$ & 60 & 61 & 61 & 62 & 57 & 65 & 57 & 61 & 67 & 65 & 70 & 63 & 73 & 61 & 60 \\
\hline $\mathrm{Hf}$ & & & & 1.87 & & 1.86 & & & 2.04 & 1.86 & & 2.04 & & & \\
\hline $\mathrm{Ta}$ & & & & 0.03 & & 0.83 & & & 0.42 & 0.32 & & 0.62 & & & \\
\hline Th & & & & 0.28 & & 0.28 & & & 0.29 & 0.26 & & 0.29 & & & \\
\hline $\mathrm{U}$ & & & & 0.06 & & 0.11 & & & 0.06 & 0.06 & & 0.05 & & & \\
\hline
\end{tabular}


Table 5. (continued).

\begin{tabular}{|c|c|c|c|c|c|c|c|c|c|c|c|c|c|c|c|}
\hline $462 \mathrm{~A}-17$ & $462 A-18$ & $462 A-19$ & $462 A-20$ & $462 A-21$ & $462 A-22$ & $462 A-23$ & $462 \mathrm{~A}-24$ & $462 A-25$ & $462 A-26$ & $462 \mathrm{~A}-27$ & $462 A-28$ & $462 A-29$ & $462 \mathrm{~A}-30$ & $462 A-31$ & $462 \mathrm{~A}-32$ \\
\hline 50.37 & 50.01 & 50.44 & 49.15 & 49.35 & 49.60 & 50.03 & 51.16 & 50.19 & 51.41 & 50.31 & 50.00 & 50.76 & 49.97 & 50.91 & 50.27 \\
\hline 1.25 & 1.24 & 1.27 & 1.29 & 1.30 & 1.23 & 1.27 & 1.19 & 1.20 & 1.21 & 1.23 & 1.25 & 1.22 & 1.22 & 1.18 & 1.18 \\
\hline 13.93 & 13.87 & 13.84 & 14.08 & 14.17 & 13.61 & 14.19 & 13.76 & 13.99 & 13.81 & 14.24 & 14.19 & 13.82 & 14.30 & 13.76 & 13.79 \\
\hline 3.37 & 3.88 & 3.75 & 4.02 & 3.98 & 3.72 & 4.52 & 4.65 & 4.15 & 4.21 & 4.21 & 3.90 & 4.08 & 4.45 & 4.01 & 3.86 \\
\hline 9.23 & 8.94 & 9.74 & 9.35 & 9.53 & 9.04 & 8.85 & 8.26 & 8.36 & 8.20 & 7.95 & 8.29 & 8.28 & 8.60 & 8.84 & 8.96 \\
\hline 0.20 & 0.22 & 0.22 & 0.20 & 0.20 & 0.46 & 0.20 & 0.19 & 0.20 & 0.20 & 0.22 & 0.20 & 0.20 & 0.20 & 0.20 & 0.20 \\
\hline 7.13 & 6.84 & 6.76 & 6.89 & 6.91 & 6.74 & 6.90 & 6.59 & 6.58 & 6.80 & 6.91 & 6.64 & 6.52 & 6.76 & 6.76 & 6.87 \\
\hline 11.37 & 10.83 & 11.90 & 11.61 & 11.71 & 11.66 & 11.74 & 11.35 & 11.72 & 11.18 & 11.39 & 11.35 & 11.26 & 11.82 & 11.47 & 11.50 \\
\hline 2.53 & 2.43 & 2.36 & 2.44 & 2.35 & 2.22 & 2.67 & 2.38 & 2.47 & 2.55 & 2.81 & 2.83 & 2.45 & 2.38 & 2.34 & 2.27 \\
\hline 0.13 & 0.53 & 0.12 & 0.15 & 0.13 & 0.17 & 0.12 & 0.12 & 0.12 & 0.12 & 0.12 & 0.13 & 0.13 & 0.12 & 0.12 & 0.13 \\
\hline 0.10 & 0.11 & 0.11 & 0.10 & 0.11 & 0.10 & 0.11 & 0.11 & 0.11 & 0.11 & 0.10 & 0.11 & 0.11 & 0.10 & 0.10 & 0.10 \\
\hline 0.85 & 1.10 & 0.69 & 0.88 & 1.01 & 0.83 & 0.54 & 1.03 & 1.20 & 0.98 & 1.40 & 0.93 & 0.99 & 1.03 & 0.88 & 0.95 \\
\hline 0.07 & 0.09 & 0.08 & 0.05 & 0.07 & 0.20 & 0.02 & 0.02 & 0.02 & 0.02 & 0.02 & 0.02 & 0.02 & 0.02 & 0.02 & 0.02 \\
\hline 100.53 & 10.09 & 101.28 & 100.21 & 100.82 & 99.58 & 101.16 & 100.81 & 100.31 & 100.80 & 100.91 & 99.84 & 99.84 & 100.97 & 100.59 & 100.10 \\
\hline 2.97 & 2.93 & 2.98 & 2.98 & 2.95 & 2.95 & 2.92 & 2.96 & 2.92 & 2.91 & 2.87 & 2.84 & 3.01 & 3.20 & 2.93 & 2.99 \\
\hline 1.72 & 1.82 & 1.94 & 1.88 & 1.90 & 1.84 & 1.87 & 1.89 & 1.84 & 1.76 & 1.70 & 1.78 & 1.83 & 1.86 & 1.84 & 1.81 \\
\hline 0.37 & 0.43 & 0.39 & 0.43 & 0.42 & 0.41 & 0.51 & 0.56 & 0.50 & 0.51 & 0.53 & 0.47 & 0.49 & 0.52 & 0.45 & 0.43 \\
\hline 29 & 19 & 5 & 5 & 5 & 5 & 9 & 5 & 5 & 5 & 5 & 9 & 5 & 5 & 5 & 5 \\
\hline 16 & 15 & 13 & 11 & 15 & 16 & 11 & 9 & 9 & 10 & 15 & 10 & 11 & 14 & 8 & 8 \\
\hline 166 & 170 & 166 & 159 & 164 & 170 & 147 & 152 & 157 & 150 & 164 & 155 & 152 & 155 & 147 & 161 \\
\hline 6 & 5 & 5 & 4 & 5 & 6 & 4 & 4 & 4 & 5 & 5 & 4 & 3 & 5 & 4 & 3 \\
\hline 5 & 5 & 4 & 4 & 5 & 5 & 7 & 6 & 4 & 5 & 5 & 4 & 4 & 5 & 5 & 6 \\
\hline 9 & 9 & 11 & 8 & 8 & 9 & 8 & 5 & 8 & 9 & 11 & 8 & 8 & 10 & 7 & 7 \\
\hline 84 & 90 & 87 & 86 & 84 & 87 & 83 & 82 & 84 & 87 & 86 & 89 & 86 & 85 & 78 & 82 \\
\hline 6 & 8 & 6 & 4 & 3 & 6 & 4 & 7 & 2 & 2 & 3 & 2 & 4 & 5 & 2 & 4 \\
\hline 42 & 43 & 42 & 41 & 45 & 46 & 42 & 46 & 46 & 44 & 47 & 48 & 47 & 46 & 44 & 45 \\
\hline 107 & 107 & 111 & 111 & 108 & 109 & 110 & 108 & 108 & 109 & 103 & 109 & 111 & 114 & 111 & 108 \\
\hline 28 & 31 & 31 & 32 & 32 & 28 & 28 & 25 & 26 & 31 & 29 & 29 & 29 & 28 & 24 & 25 \\
\hline 58 & 58 & 67 & 63 & 61 & 65 & 68 & 60 & 66 & 69 & 71 & 63 & 63 & 65 & 57 & 55 \\
\hline 1.94 & & 1.90 & & 2.04 & 1.93 & 1.86 & & 1.76 & & & 1.80 & & & & 1.85 \\
\hline 0.76 & & 0.65 & & 1.06 & 0.86 & 0.87 & & 0.71 & & & 0.58 & & & & 0.63 \\
\hline 0.25 & & 0.26 & & 0.28 & 0.266 & 0.28 & & 0.26 & & & 0.30 & & & & 0.29 \\
\hline 0.05 & & 0.09 & & 0.08 & 0.071 & 0.062 & & 0.07 & & & 0.07 & & & & 0.09 \\
\hline
\end{tabular}

Table 5. (continued).

\begin{tabular}{|c|c|c|c|c|c|c|c|c|c|c|c|c|c|c|c|}
\hline $462 \mathrm{~A}-48$ & $462 \mathrm{~A}-49$ & $462 \mathrm{~A}-50$ & $462 \mathrm{~A}-51$ & $462 \mathrm{~A}-52$ & $462 \mathrm{~A}-53$ & $462 A-54$ & 462A-55 & $462 A-56$ & $462 \mathrm{~A}-57$ & $462 A-58$ & $462 A-59$ & $462 \mathrm{~A}-60$ & $462 \mathrm{~A}-61$ & $462 \mathrm{~A}-62$ & $462 \mathrm{~A}-63$ \\
\hline 50.07 & 49.57 & 49.36 & 51.00 & 50.28 & 49.41 & 50.18 & 49.86 & 50.69 & 50.37 & 50.90 & 51.06 & 51.03 & 50.68 & 50.88 & 50.75 \\
\hline 1.26 & 1.22 & 1.25 & 1.25 & 1.29 & 1.25 & 1.26 & 1.23 & 1.22 & 1.22 & 1.21 & 1.24 & 1.22 & 1.21 & 1.23 & 1.31 \\
\hline 14.10 & 14.09 & 13.94 & 14.05 & 13.72 & 13.97 & 14.06 & 13.96 & 13.89 & 13.94 & 13.65 & 13.76 & 13.78 & 13.66 & 13.95 & 13.61 \\
\hline 3.62 & 4.39 & 4.45 & 4.24 & 4.42 & 4.27 & 4.27 & 4.39 & 4.32 & 4.26 & 4.05 & 4.35 & 4.35 & 4.00 & 4.02 & 4.13 \\
\hline 8.89 & 8.65 & 8.89 & 7.80 & 8.23 & 8.42 & 8.34 & 8.82 & 8.72 & 8.65 & 8.91 & 8.86 & 8.65 & 8.99 & 8.68 & 8.89 \\
\hline 0.22 & 0.23 & 0.23 & 0.23 & 0.23 & 0.26 & 0.23 & 0.25 & 0.20 & 0.19 & 0.20 & 0.20 & 0.20 & 0.20 & 0.20 & 0.22 \\
\hline 6.47 & 6.89 & 6.90 & 6.18 & 6.59 & 6.83 & 6.75 & 6.78 & 6.47 & 6.75 & 6.52 & 6.53 & 6.66 & 6.37 & 6.51 & 6.22 \\
\hline 11.84 & 11.46 & 11.61 & 11.24 & 10.97 & 11.38 & 11.43 & 11.89 & 11.72 & 11.56 & 11.22 & 11.34 & 11.39 & 10.73 & 11.05 & 10.75 \\
\hline 2.51 & 2.71 & 2.33 & 2.99 & 2.84 & 2.41 & 2.55 & 2.36 & 2.49 & 2.39 & 2.44 & 2.33 & 2.35 & 2.21 & 2.46 & 2.44 \\
\hline 0.13 & 0.13 & 0.14 & 0.13 & 0.14 & 0.14 & 0.13 & 0.13 & 0.12 & 0.12 & 0.12 & 0.12 & 0.15 & 0.43 & 0.57 & 0.42 \\
\hline 0.11 & 0.10 & 0.11 & 0.11 & 0.11 & 0.09 & 0.11 & 0.10 & 0.10 & 0.10 & 0.11 & 0.10 & 0.11 & 0.10 & 0.10 & 0.11 \\
\hline 1.13 & 1.20 & 1.32 & 1.07 & 1.25 & 1.29 & 1.10 & 1.05 & 0.95 & 0.87 & 0.96 & 0.96 & 1.07 & 1.08 & 0.97 & 1.11 \\
\hline 0.02 & 0.02 & 0.02 & 0.04 & 0.02 & 0.02 & 0.02 & 0.03 & 0.03 & 0.02 & 0.03 & 0.02 & 0.02 & 0.02 & 0.02 & 0.02 \\
\hline 100.37 & 100.66 & 100.55 & 100.33 & 100.09 & 99.74 & 100.43 & 100.85 & 100.92 & 100.47 & 100.32 & 100.87 & 100.98 & 99.68 & 100.64 & 99.98 \\
\hline 2.90 & 2.79 & 2.87 & 2.80 & 2.89 & 2.85 & 2.88 & 2.91 & 2.93 & 2.90 & 2.96 & 2.95 & 2.98 & 2.96 & 2.97 & 2.99 \\
\hline 1.88 & 1.83 & 1.87 & 1.88 & 1.85 & 1.80 & 1.80 & 1.88 & 1.95 & 1.85 & 1.93 & 1.94 & 1.89 & 1.98 & 1.89 & 2.03 \\
\hline 0.41 & 0.51 & 0.50 & 0.54 & 0.54 & 0.51 & 0.51 & 0.50 & 0.50 & 0.49 & 0.45 & 0.49 & 0.50 & 0.44 & 0.46 & 0.46 \\
\hline 5 & 5 & 8 & 5 & 19 & 18 & 5 & 5 & 9 & 5 & 5 & 5 & 8 & 40 & 29 & 28 \\
\hline 16 & 18 & 18 & 19 & 13 & 13 & 13 & 12 & 12 & 13 & 10 & 10 & 14 & 15 & 12 & 14 \\
\hline 137 & 146 & 143 & 144 & 145 & 140 & 143 & 141 & 142 & 138 & 138 & 141 & 141 & 138 & 139 & 130 \\
\hline 5 & 6 & 6 & 7 & 5 & 5 & 5 & 3 & 3 & 5 & 4 & 4 & 5 & 6 & 5 & 5 \\
\hline 5 & 5 & 5 & 5 & 5 & 5 & 6 & 5 & 5 & 5 & 6 & 5 & 6 & 5 & 6 & 5 \\
\hline 10 & 14 & 14 & 15 & 11 & 10 & 10 & 9 & 9 & 6 & 9 & 8 & 12 & 14 & 9 & 12 \\
\hline 82 & 81 & 79 & 83 & 79 & 77 & 77 & 78 & 83 & 80 & 79 & 78 & 76 & 77 & 79 & 66 \\
\hline 3 & 5 & 6 & 4 & 2 & 2 & 2 & 2 & 5 & 4 & 3 & 2 & 2 & 8 & 8 & 6 \\
\hline 47 & 47 & 49 & 51 & 47 & 48 & 48 & 47 & 47 & 46 & 47 & 48 & 49 & 45 & 45 & 46 \\
\hline 117 & 105 & 112 & 106 & 105 & 107 & 109 & 110 & 111 & 111 & 111 & 112 & 110 & 105 & 107 & 109 \\
\hline 29 & 32 & 30 & 33 & 27 & 29 & 29 & 25 & 25 & 27 & 25 & 27 & 28 & 32 & 29 & 31 \\
\hline 63 & 69 & 73 & 73 & 61 & 62 & 62 & 60 & 60 & 65 & 61 & 60 & 67 & 73 & 65 & 71 \\
\hline 1.84 & 1.96 & 2.14 & 1.87 & 1.97 & 1.78 & 1.89 & 1.96 & & 1.88 & & & 1.95 & 1.79 & 1.77 & \\
\hline 0.48 & 0.56 & 0.93 & 0.43 & 0.67 & 0.32 & 0.42 & 0.64 & & 0.70 & & & 0.46 & 0.46 & 0.46 & \\
\hline 0.29 & 0.30 & 0.32 & 0.31 & 0.33 & 0.29 & 0.29 & 0.28 & & 0.29 & & & 0.29 & 0.26 & 0.26 & \\
\hline 0.07 & 0.04 & 0.07 & 0.08 & 0.10 & 0.10 & 0.08 & 0.06 & & 0.09 & & & 0.08 & 0.05 & 0.05 & \\
\hline
\end{tabular}


Table 5. (continued).

\begin{tabular}{|c|c|c|c|c|c|c|c|c|c|c|c|c|}
\hline & $462 \mathrm{~A}-64$ & $462 A-65$ & $462 A-66$ & $462 \mathrm{~A}-67$ & $462 \mathrm{~A}-68$ & $462 A-69$ & $462 A-70$ & 462A-71 & $462 A-72$ & $462 \mathrm{~A}-73$ & $462 \mathrm{~A}-74$ & $462 \mathrm{~A}-75$ \\
\hline $\mathrm{SiO}_{2}$ & 47.84 & 47.44 & 50.62 & 51.12 & 50.25 & 50.08 & 49.55 & 49.57 & 49.66 & 50.07 & 50.25 & 49.87 \\
\hline $\mathrm{TiO}_{2}$ & 1.15 & 1.15 & 1.22 & 1.25 & 1.30 & 1.30 & 1.29 & 1.32 & 1.30 & 1.31 & 1.34 & 1.33 \\
\hline $\mathrm{Al}_{2} \mathrm{O}_{3}$ & 12.94 & 12.89 & 13.63 & 13.56 & 14.06 & 13.67 & 13.83 & 13.73 & 13.57 & 14.10 & 14.41 & 13.88 \\
\hline $\mathrm{Fe}_{2} \mathrm{O}_{3}$ & 3.43 & 3.18 & 3.57 & 4.15 & 4.46 & 4.71 & 4.31 & 4.43 & 4.32 & 4.71 & 4.47 & 4.46 \\
\hline $\mathrm{FeO}$ & 8.68 & 8.95 & 9.00 & 8.88 & 7.81 & 8.80 & 8.92 & 8.89 & 9.00 & 8.87 & 8.05 & 8.04 \\
\hline $\mathrm{MnO}$ & 0.19 & 0.19 & 0.20 & 0.20 & 0.20 & 0.25 & 0.25 & 0.23 & 0.20 & 0.22 & 0.22 & 0.20 \\
\hline $\mathrm{MgO}$ & 6.16 & 6.05 & 6.35 & 6.56 & 6.65 & 6.33 & 7.15 & 6.72 & 6.28 & 6.93 & 6.69 & 6.80 \\
\hline $\mathrm{CaO}$ & 10.45 & 10.52 & 11.15 & 11.49 & 11.25 & 11.72 & 11.51 & 11.61 & 11.36 & 11.50 & 11.05 & 10.52 \\
\hline $\mathrm{Na}_{2} \mathrm{O}$ & 2.43 & 2.34 & 2.35 & 2.38 & 2.34 & 2.53 & 2.54 & 2.50 & 2.57 & 2.53 & 3.03 & 3.51 \\
\hline $\mathrm{K}_{2} \mathrm{O}$ & 0.32 & 0.13 & 0.13 & 0.13 & 0.12 & 0.17 & 0.15 & 0.16 & 0.13 & 0.13 & 0.13 & 0.13 \\
\hline $\mathrm{P}_{2} \mathrm{O}_{5}$ & 0.10 & 0.09 & 0.11 & 0.10 & 0.10 & 0.11 & 0.11 & 0.10 & 0.10 & 0.11 & 0.11 & 0.11 \\
\hline $\mathrm{H}_{2} \mathrm{O}^{+}$ & 6.05 & 6.16 & 1.10 & 0.96 & 1.66 & 1.14 & 1.14 & 1.16 & 1.13 & 1.08 & 1.32 & 1.25 \\
\hline $\mathrm{CO}_{2}$ & 0.04 & 0.04 & 0.02 & 0.03 & 0.02 & 0.02 & 0.03 & 0.02 & 0.03 & 0.03 & 0.03 & 0.02 \\
\hline Total & 99.78 & 99.13 & 99.45 & 100.81 & 100.22 & 100.83 & 100.78 & 100.44 & 99.55 & 101.59 & 101.10 & 100.12 \\
\hline S.G. ${ }^{a}$ & 2.96 & 2.94 & 2.98 & 3.03 & 2.91 & 2.90 & 2.91 & 2.93 & 2.92 & 2.93 & 2.71 & 2.80 \\
\hline $\mathrm{FeO} * / \mathrm{MgO}$ & 1.91 & 1.95 & 1.92 & 1.92 & 1.78 & 2.06 & 1.79 & 1.92 & 2.05 & 1.89 & 1.80 & 1.77 \\
\hline $\mathrm{Fe}_{2} \mathrm{O}_{3} / \mathrm{FeO}$ & 0.40 & 0.36 & 0.40 & 0.47 & 0.57 & 0.54 & 0.48 & 0.50 & 0.48 & 0.53 & 0.56 & 0.55 \\
\hline $\mathrm{Ba}$ & 8 & 21 & 5 & 13 & 5 & 7 & 5 & 5 & 5 & 27 & 32 & 29 \\
\hline $\mathrm{Ce}$ & 10 & 8 & 13 & 9 & 24 & 17 & 22 & 17 & 16 & 17 & 18 & 20 \\
\hline $\mathrm{Cr}$ & 139 & 147 & 144 & 144 & 148 & 124 & 118 & 123 & 118 & 117 & 115 & 119 \\
\hline La & 4 & 3 & 5 & 4 & 8 & 6 & 8 & 7 & 5 & 6 & 8 & 7 \\
\hline $\mathrm{Nb}$ & 5 & 5 & 5 & 6 & 7 & 6 & 5 & 5 & 5 & 5 & 5 & 5 \\
\hline Nd & 9 & 5 & 9 & 8 & 16 & 10 & 13 & 11 & 10 & 10 & 11 & 13 \\
\hline $\mathrm{Ni}$ & 78 & 82 & 81 & 77 & 81 & 74 & 75 & 76 & 75 & 73 & 74 & 79 \\
\hline $\mathrm{Rb}$ & 7 & 6 & 5 & 7 & 3 & 4 & 2 & 4 & 3 & 7 & 4 & 6 \\
\hline $\mathrm{Sc}$ & 44 & 45 & 45 & 46 & 50 & 47 & 47 & 49 & 46 & 49 & 48 & 49 \\
\hline $\mathrm{Sr}$ & 108 & 112 & 111 & 111 & 116 & 115 & 113 & 112 & 119 & 115 & 113 & 107 \\
\hline $\mathbf{Y}$ & 27 & 29 & 27 & 29 & 32 & 28 & 31 & 30 & 30 & 30 & 32 & 28 \\
\hline $\mathrm{Zr}$ & 63 & 69 & 66 & 62 & 78 & 62 & 67 & 67 & 61 & 68 & 73 & 73 \\
\hline Hf & 2.06 & & 2.07 & & 2.24 & & 1.94 & & & 2.21 & & 2.26 \\
\hline $\mathrm{Ta}$ & 0.44 & & 0.60 & & 0.46 & & 0.63 & & & 0.41 & & 0.79 \\
\hline Th & 0.29 & & 0.29 & & 0.34 & & 0.30 & & & 0.29 & & 0.34 \\
\hline $\mathrm{U}$ & 0.08 & & 0.10 & & 0.10 & & 0.07 & & & 0.10 & & 0.10 \\
\hline
\end{tabular}

creases with depth, but $\mathrm{TiO}_{2}$ is lowest at intermediate levels and some $\mathrm{Zr}$ contents are as high at the top of the pile as at the base. In general, the fine detail of the chemical variation, relative to the gross trends, precludes a simple genetic relationship between all the volcanic units, or indeed between only the aphyric units as representatives of initial melts.

\section{Chemical Megagroups and Petrogenetic Implications}

Chemical groups representing different magma batches include rocks of overall similar composition, as well as those whose members can be related by the low-pressure fractionation (addition and subtraction) of observed phenocryst phases from a parental magma. Variation between the parental magmas of each independently fractionated chemical group may reflect the operation of high-pressure fractionation, variable partial melting of a uniform source, or, possibly, generation from heterogeneous mantle.

The group discriminant used was $\mathrm{TiO}_{2}$, which shows a marked difference between Volcanic Units 48 to 52 , in the central portion of the hole, relative to those at the top and bottom, and allows division of the basalts into three megagroups, A, B, and C, in order of increasing depth (Figs. 9, 10). Little overlap between the megagroups is seen even when the analytical error is taken into account, although differences between megagroups $\mathrm{A}$ and $\mathrm{C}$ are less marked when the standard deviation is considered. Average $\mathrm{TiO}_{2} \pm$ standard deviation is $1.28 \pm 0.03$ for group A, $1.22 \pm 0.04$ for $\mathrm{B}$, and $1.31 \pm 0.02$ for $\mathrm{C}$. Other chemical distinctions between the three megagroups are apparent, however, from averaged data (Table 8) and elemental distributions relative to $\mathrm{TiO}_{2}$ content (Fig. 11).
Megagroup A, in particular, is characterized by generally higher siderophile-element contents (but oddly lower $\mathrm{Sc}$ ), whereas megagroup $\mathrm{C}$ is typical higher in many incompatible trace elements. At a particular $\mathrm{TiO}_{2}$ content, the major distinctions are in the levels of siderophile trace elements, but incompatible-element variations are less well defined (Fig. 11).

Because the $\mathrm{FeO} * \mathrm{MgO}$ ratio shows some variability caused by secondary alteration, the $\mathrm{Zr}$ content has been used as a stable index to demonstrate variable fractionation, even though the range $(25 \mathrm{ppm})$ is very limited (Fig. 12). Variably phyric basalts are present in each of the megagroups, and overlap the compositional range shown by any associated aphyric basalts, as for example, aphyric Volcanic Unit 45 and phyric Unit 46 (Fig. $12, \mathrm{Zr}-\mathrm{Cr}$ plot). The gross variation displayed can be broadly related via fractionation of the main observed phenocryst phases within each megagroup:

1. Megagroup A (phenocrysts: clinopyroxene-olivine, minor plagioclase). Clinopyroxene fractionation is indicated by the decrease in both $\mathrm{Cr}$ and $\mathrm{Sc}$ with progressive $\mathrm{Zr}$ content. Ni also decreases (not shown), and is indicative of olivine fractionation, although alteration of olivine microphenocrysts to smectite has caused considerable scatter in the Ni data. Y content shows little variation, and thus produces variable $\mathrm{Zr} / \mathrm{Y}$ ratios, again suggesting fractionation of clinopyroxene, which can accommodate $\mathrm{Y}$ in its structure. Partial melting involving a Y-bearing phase (e.g., pyroxene, garnet) can also cause variation in $\mathrm{Zr} / \mathrm{Y}$, but to a much greater degree than clinopyroxene fractionation (Pearce and Norry, 1979). The chemical stratigraphy (Fig. 9) shows that the lower $\mathrm{Zr} / \mathrm{Y}$ ratios are confined to Unit 46 and the phyric base of 
Table 6. Normative composition of Nauru Basin basaltic lava flows (Hole 462A), calculated on anhydrous, carbonate-free basis and an $\mathrm{Fe}_{2} \mathrm{O}_{3} / \mathrm{FeO}$ of 0.15 .

\begin{tabular}{|c|c|c|c|c|c|c|c|c|c|c|c|c|c|}
\hline \multirow{2}{*}{$\begin{array}{c}\text { Keele } \\
\text { number }\end{array}$} & \multirow[b]{2}{*}{ Qz } & \multirow[b]{2}{*}{ Or } & \multirow[b]{2}{*}{$A b$} & & & & & & & & & & \\
\hline & & & & An & $\mathrm{Di}$ & Hy & Ol & Mt & II & Ap & Di & En & Fo \\
\hline $462 \mathrm{~A}-1$ & - & 0.78 & 21.78 & 28.03 & 24.94 & 11.66 & 7.58 & 2.42 & 2.55 & 0.26 & 53 & 50 & 47 \\
\hline $462 \mathrm{~A}-2$ & 0.52 & 0.83 & 20.91 & 26.99 & 23.87 & 21.70 & - & 2.49 & 2.43 & 0.26 & 50 & 47 & - \\
\hline $462 A-3$ & 0.10 & 0.82 & 21.11 & 26.17 & 24.01 & 22.57 & - & 2.47 & 2.49 & 0.26 & 52 & 49 & - \\
\hline $462 \mathrm{~A}-4$ & - & 0.90 & 21.28 & 27.14 & 25.33 & 17.72 & 2.59 & 2.33 & 2.48 & 0.24 & 54 & 51 & 49 \\
\hline $462 A-5$ & - & 0.71 & 19.80 & 27.50 & 24.73 & 17.19 & 4.78 & 2.53 & 2.53 & 0.26 & 53 & 50 & 47 \\
\hline $462 \mathrm{~A}-6$ & - & 0.77 & 20.83 & 27.58 & 24.27 & 19.59 & 1.81 & 24.1 & 2.50 & 0.26 & 53 & 50 & 47 \\
\hline $462 \mathrm{~A}-7$ & 0.45 & 0.71 & 20.35 & 27.05 & 24.40 & 21.92 & - & 2.43 & 2.44 & 0.26 & 52 & 49 & - \\
\hline $462 \mathrm{~A}-8$ & - & 0.72 & 20.40 & 26.44 & 23.45 & 23.79 & 0.02 & 2.47 & 2.46 & 0.26 & 53 & 50 & 47 \\
\hline $462 \mathrm{~A}-9$ & - & 0.89 & 21. & 25.27 & 25.13 & 19.69 & 2.36 & 2.50 & 2.42 & 0.24 & 53 & 49 & 47 \\
\hline $462 \mathrm{~A}-10$ & - & 0.77 & 20. & 27. & 24.79 & 15 & 4.91 & 2.43 & 2.52 & 0.26 & 53 & 50 & 48 \\
\hline $462 \mathrm{~A}-11$ & - & 1.92 & 19. & 26. & 21.60 & 25 & 0.13 & 2.49 & 2.37 & 0. & 53 & 50 & 46 \\
\hline $462 \mathrm{~A}-12$ & 0.20 & 0.72 & 20. & 27. & 19.69 & 26.16 & - & 2.53 & 2.51 & 0.26 & 53 & 50 & - \\
\hline $462 \mathrm{~A}-13$ & - & 0.72 & 20. & 26. & 24.44 & 18 & .98 & 2.41 & 2.53 & 0.24 & 54 & 51 & 48 \\
\hline $462 \mathrm{~A}-14$ & 3.57 & 0.99 & 16. & 30. & 10 & 3 & - & & 2.45 & 22 & 56 & 3 & - \\
\hline $462 \mathrm{~A}-15$ & - & 0.72 & 23. & 26 & 23 & & & & 2.54 & & 54 & 1 & 48 \\
\hline 462 & - & 0.77 & 21. & 26 & 24 & & & 2.44 & 1 & & . & 50 & 47 \\
\hline 46 & - & 0. & 21. & 26 & 24 & & 9 & & 9 & 24 & 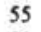 & 1 & 49 \\
\hline 46 & - & 3 & 20 & 2 & 2 & & 99 & 2 & 2.39 & 26 & 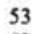 & 0 & 48 \\
\hline 46 & - & 0 & 19 & 2 & 2 & & 0.96 & 2.51 & 2.41 & .26 & 2 & 48 & 46 \\
\hline $462 \mathrm{~A}-20$ & - & 0.90 & 20 & 2 & 2 & 1 & 5.84 & 2.51 & 2.48 & 0.24 & $S$ & 49 & 47 \\
\hline $462 A-21$ & - & 0.77 & 20.00 & 27.89 & 24.23 & 17.21 & 4.52 & 2.53 & 2.48 & 0.26 & 52 & 49 & 46 \\
\hline $462 A-22$ & 0.18 & 1.02 & 19.15 & 27.19 & 24.72 & 22.71 & - & 2.42 & 2.38 & 0.24 & 5 & 49 & - \\
\hline $462 \mathrm{~A}-23$ & - & 0.71 & 22.53 & 26.30 & 25.62 & 12.94 & 6.79 & 2.47 & 2.41 & 0.26 & 53 & 49 & 47 \\
\hline $462 \mathrm{~A}-24$ & 1.55 & 0.71 & 20.25 & 26.65 & 24.12 & 21.73 & - & 2.35 & 2.35 & 0.26 & 52 & 49 & - \\
\hline $462 A-25$ & - & 0.72 & 21.15 & 27.05 & 25.61 & 20.08 & 0.48 & 2.35 & 2.31 & 0.26 & 3 & 50 & 47 \\
\hline $462 A-26$ & 1.11 & 0.71 & 21.68 & 26.01 & 23.87 & 21.75 & - & 2.31 & 2.31 & 0.26 & 4 & 51 & - \\
\hline $462 A-27$ & - & 0.71 & 23.97 & 26.10 & 24.83 & 14.64 & 4.89 & 2.27 & 2.36 & 0.24 & 6 & 52 & 49 \\
\hline $462 A-28$ & - & 0.78 & 24.28 & 25.99 & 25.00 & 14.17 & 4.83 & 2.29 & 2.41 & 0.26 & 4 & 51 & 48 \\
\hline 462A-29 & 1.28 & 0.7 & 21.0 & 26. & 24.0 & 21. & - & 2.32 & 2.35 & 6 & 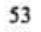 & 50 & - \\
\hline $462 A-30$ & - & 0.7 & 20. & 28. & 24. & 1 & 2.42 & 2.42 & 2. & 0.24 & 4 & 49 & 47 \\
\hline $462 \mathrm{~A}-31$ & 1.05 & 0.71 & 19. & 26. & 24 & 2 & - & 2.40 & 2.25 & 0.24 & 53 & 49 & - \\
\hline $462 A-32$ & 0.51 & 0.77 & 19.43 & 27.36 & 24.45 & 22. & - & 2.41 & 2.27 & 0.24 & 53 & 50 & - \\
\hline $462 \mathrm{~A}-33$ & 1.44 & 0.77 & 19.59 & 27.21 & 24.16 & 21. & - & 2.42 & 2.28 & 0.24 & 2 & 49 & - \\
\hline $462 \mathrm{~A}-34$ & 0.92 & 0.78 & 19. & 27. & 23. & 22 & - & 2.37 & 2.27 & 4 & 4 & 51 & - \\
\hline $462 \mathrm{~A}-35$ & - & 0.72 & 19. & 27. & 23 & 2 & 0.17 & 2.40 & 2.26 & 0.24 & 4 & 50 & 48 \\
\hline $462 A-36$ & 1.38 & 0.71 & 19. & 27. & 2 & 2 & - & 2.33 & 6 & 4 & 54 & 51 & - \\
\hline $462 A-37$ & 0. & 0.77 & 20. & 27. & 2 & 2 & - & 2.43 & 5 & 24 & 52 & 49 & - \\
\hline 462A-38 & 0.76 & 0.71 & 20. & 26 & 2 & 2 & - & 2.41 & 2. & 26 & 3 & 49 & - \\
\hline 462 & 0.72 & 0.77 & 20. & 26 & 2 & & - & 2.40 & 4 & 24 & 3 & 49 & - \\
\hline $1-40$ & 1.46 & 0.77 & 20. & 27 & 2 & 2 & - & 2.37 & 37 & 24 & 3 & 49 & - \\
\hline-41 & 1.51 & 0.91 & 20 & 27 & 2 & 2 & - & 2.40 & 41 & 27 & 2 & 49 & - \\
\hline $462 \mathrm{~A}-42$ & 0.65 & 0.84 & 20 & 27. & 2 & 2 & - & 2.39 & 39 & 4 & 2 & 99 & - \\
\hline 462 & - & $1 .($ & 20 & 27 & 2 & 1 & .85 & 2 & 9 & 4 & 3 & 49 & 7 \\
\hline 462 & - & 1. & 19 & 27 & 2 & 1 & 12 & 2 & 0 & 6 & 2 & 9 & 46 \\
\hline 462 & - & 0. & 2 & 26 & 2 & 0 & 51 & 2 & 8 & 4 & 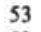 & 50 & 47 \\
\hline $462 \mathrm{~A}$ & - & 0. & 2 & 2 & 2 & 4 & 99 & 2 & 2.36 & 0.26 & 1 & 49 & 46 \\
\hline $462 \mathrm{~A}-47$ & - & 1.01 & 20.09 & 27.37 & 2 & 1 & 2.76 & 2.43 & 2.39 & 0.26 & 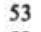 & 50 & 47 \\
\hline $462 \mathrm{~A}-48$ & - & 0.78 & 21.46 & 27.10 & 26.00 & 18.09 & 1.57 & 2.35 & 2.42 & 0.26 & 53 & 49 & 46 \\
\hline $462 \mathrm{~A}-49$ & - & 0.77 & 23.13 & 26.12 & 25.20 & 12.44 & 7.34 & 2.44 & 2.34 & 0.24 & 53 & 50 & 47 \\
\hline $462 \mathrm{~A}-50$ & - & 0.84 & 19.93 & 27.46 & 24.78 & 18.29 & 3.55 & 2.50 & 2.40 & 0.26 & 3 & 49 & 46 \\
\hline $462 \mathrm{~A}-51$ & - & 0.78 & 25.58 & 24.81 & 25.34 & 17.26 & 1.33 & 2.25 & 2.40 & 0.26 & 53 & 49 & 47 \\
\hline $462 A-52$ & - & 0.84 & 24.4 & 24.64 & 24.63 & 17.47 & 2.91 & 2.37 & 2.49 & 0.26 & 3 & so & 47 \\
\hline $462 A-53$ & - & 0.8 & 20.7 & 27.4 & 24.32 & 19. & 2.49 & 2. & 2.42 & 0.22 & 4 & 50 & 48 \\
\hline $462 \mathrm{~A}-54$ & - & 0.7 & 1.7 & 26.8 & 24 & 19. & 1.76 & 2.36 & 2. & 0.26 & 4 & 50 & 48 \\
\hline $462 \mathrm{~A}-55$ & - & 0.7 & 0.0 & 27.2 & 25. & 18. & 2.67 & 2.46 & 2.35 & 0.24 & 2 & 49 & 46 \\
\hline $462 A-56$ & 0.12 & 0.71 & 21.15 & 26.4 & 25.7 & 20. & - & 2.42 & 2.33 & 0.24 & 52 & 48 & - \\
\hline $462 \mathrm{~A}-57$ & .07 & 0.71 & 20.3 & 27.1 & 24.7 & 22. & - & 2.42 & 2.33 & 0.24 & 53 & 49 & - \\
\hline $462 \mathrm{~A}-58$ & 1.23 & 0.7 & 20.8 & 26.19 & 24. & 1. & - & 2.43 & 2.32 & 0.26 & 52 & 48 & - \\
\hline $462 A-59$ & 1.55 & 0.71 & 19.80 & 26.84 & 23.95 & 22.11 & - & 2.46 & 2.36 & 0.24 & 51 & 48 & - \\
\hline $462 \mathrm{~A}-60$ & 1.21 & 0.89 & 19.97 & 26.72 & 24.17 & 22.05 & - & 2.42 & 2.33 & 0.26 & 52 & 49 & - \\
\hline $462 \mathrm{~A}-61$ & 1.85 & 2.58 & 19.02 & 26.53 & 22.26 & 22.74 & - & 2.45 & 2.34 & 0.24 & 51 & 48 & - \\
\hline $462 \mathrm{~A}-62$ & - & 3.38 & 20.95 & 25.50 & 23.93 & 20.87 & 0.43 & 2.37 & 2.35 & 0.24 & 52 & 49 & 47 \\
\hline $462 \mathrm{~A}-63$ & 1.11 & 2.52 & 20.95 & 25.30 & 23.20 & 21.70 & - & 2.45 & 2.52 & 0.26 & 51 & 47 & - \\
\hline $462 A-64$ & - & 2.02 & 22.00 & 25.10 & 24.38 & 21.06 & 0.45 & 2.41 & 2.34 & 0.25 & 52 & 49 & 46 \\
\hline-65 & 0.61 & 0.83 & & 26.19 & 24.22 & & - & 2.44 & 2.36 & 0.23 & 2 & 48 & - \\
\hline $462 A-66$ & 95 & 0.78 & 20.27 & 26.77 & 23.84 & 21. & - & 2.39 & 2.36 & 0.27 & 52 & 49 & - \\
\hline $462 A-67$ & 1.38 & 0.77 & 20.23 & 26.05 & 25.18 & & - & 2.43 & 2.39 & 0.24 & 2 & 49 & - \\
\hline $462 \mathrm{~A}-68$ & 1.47 & 0.12 & 0.18 & 28.33 & 22.94 & 1.90 & - & 2.31 & 2.52 & 0.24 & 4 & 51 & - \\
\hline $462 \mathrm{~A}-69$ & - & 1.01 & 21.55 & 25.61 & 26.56 & 17.70 & 2.23 & 2.52 & 2.49 & 0.26 & 50 & 47 & 44 \\
\hline $462 \mathrm{~A}-70$ & - & 0.89 & 21.64 & 26.07 & 25.24 & 14.73 & 6.24 & 2.47 & 2.47 & 0.26 & 54 & 50 & 48 \\
\hline $462 A-7$ & - & 0.96 & 13 & 26.0 & 26.01 & 16.15 & 4.22 & 2.49 & 2.53 & 0.24 & 52 & 49 & 46 \\
\hline $462 \mathrm{~A}-72$ & - & 078 & 201 & 258 & 25.73 & 1877 & 1.74 & 2.52 & 2.51 & 0.24 & 50 & 47 & 45 \\
\hline $462 A-73$ & - & 0.77 & 2138 & 26,70 & 24.34 & 17.16 & 4.43 & 2.51 & 2.48 & 0.26 & 52 & 49 & 47 \\
\hline $462 \mathrm{~A}-74$ & - & 0.77 & 25.79 & 25.48 & 23.77 & 12.22 & 6.83 & 2.33 & 2.56 & 0.26 & 54 & 50 & 48 \\
\hline $462 \mathrm{~A}-75$ & - & 0.78 & 30.14 & 22.06 & 24.84 & 4.54 & 2.48 & 2.34 & 2.56 & 0.26 & 54 & 51 & 48 \\
\hline
\end{tabular}

Note: $\mathrm{Qz}=$ quartz; $\mathrm{Or}=$ orthoclase; $\mathrm{Ab}=$ albite; $\mathrm{An}=$ anorthite; $\mathrm{Di}=$ diopside; $\mathrm{Hy}=$ hypersthene; $\mathrm{Ol}=$ olivine; $\mathrm{Mt}=$ magnetite; $\mathrm{Il}=$ ilmenite; $\mathrm{Ap}=$ apatite; $\mathrm{En}=$ enstatite; and Fo = fosterite. 


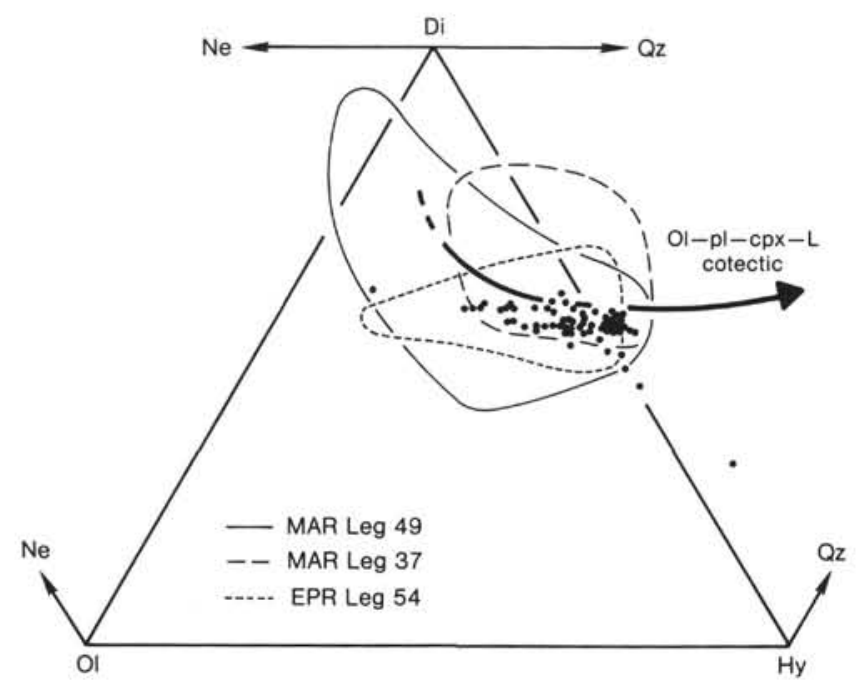

Figure 7. Distribution of Hole $462 \mathrm{~A}$ basalts in normative basalt trapezohedron, compared with MORB data from Mid-Atlantic Ridge (MAR), Legs 37 and 49 (Flower et al., 1977; Tarney et al., 1979) and East Pacific Rise (EPR), Ocean Crust Panel (Ridge), and Siqueiros Fracture Zone (Humphris, Thompson, Gibson, et al., 1980). Olivine-plagioclase-clinopyroxene-liquid cotectic at 1 atm. pressure from Thompson (1982). Qz = quartz, $\mathrm{Hy}=$ hypersthene, $\mathrm{Di}$ $=$ diopside, $\mathrm{Ol}=$ olivine; $\mathrm{Ne}=$ nepheline .

Unit 45 , both of which contain clinopyroxene as the dominant phenocryst phase (Table 4). As seen in Figure 13, the vast preponderance of the basalt suite has a relatively uniform $\mathrm{Zr} / \mathrm{Y}$ ratio (average 2.3; range 2.2-2.5), whereas the slight increase in $\mathrm{Zr} / \mathrm{Y}$ with progressive $\mathrm{Zr}$ content for Units 45 and 46 in particular is more indicative of fractionation than of partial melting. Plagioclase can also occasionally occur as a phenocryst phase, but the $\mathrm{Sr}$ distribution (Fig. 12) has been too disturbed by alteration to show any definite fractionation trend.

2. Megagroup B (phenocrysts: clinopyroxene, plagioclase, olivine). Overlap again occurs between phyric Units 49 to 51 and aphyric Unit 52, although aphyric Unit 48 is generally less evolved than the others (Fig. 12, Cr- $\mathrm{Zr}$ plot). $\mathrm{Cr}$ again decreases, but the lack of significant variation in Sc suggests that clinopyroxene fractionation was relatively minor. The systematic increase in $\mathrm{Y}$ and $\mathrm{Zr}$ (essentially constant $\mathrm{Zr} / \mathrm{Y}$ ratio) also precludes appreciable clinopyroxene removal, and is typical of olivine and/or plagioclase fractionation, which on precipitation causes a corresponding increase in both $\mathrm{Zr}$ and $\mathrm{Y}$, owing to exclusion from these phases. Olivine involvement is certainly indicated by a large decrease in $\mathrm{Ni}$ with progressive $\mathrm{Zr}$ content. Plagioclase was also fractionated, for although $\mathrm{Sr}$ is again variable, the more evolved basalts tend to have the lower $\mathrm{Sr}$ contents.

In this megagroup, unlike $\mathrm{A}$, it seems possible that phyric Units 49 to 51 may not be in fact directly related to the adjacent aphyric Units 48 and 52 . The aphyric units can be linked via olivine-plagioclase and minor clinopyroxene fractionation, as seen by decreasing $\mathrm{Ni}$, $\mathrm{Sr}$, and $\mathrm{Cr}$, respectively. The phyric units, however, have constant $\mathrm{Cr}$, and are all slightly enriched in $\mathrm{TiO}_{2}, \mathrm{Sr}, \mathrm{La}$, and $\mathrm{Ce}$, compared with aphyric Unit 52 at the same stage of chemical evolution. The phyric units also have con- stant, marginally lower $\mathrm{Zr} / \mathrm{Ce}$ ratios (4.3) compared with the higher, more variable, but similar ratios (6.1) of the two aphyric units (Fig. 14). The $\mathrm{La} / \mathrm{Nb}$ ratio is also higher in the aphyric units. As both of these ratios are unaffected by fractionation or partial melting, but reflect the source composition, two sources of slightly different composition are indicated for the megagroup B phyric and aphyric units. These features suggest that the phyric units of megagroup B are related via olivine and plagioclase fractionation, but were developed in a magma chamber independent of the aphyric units. The parental magmas were probably derived from slightly different sources (the phyric lavas being representative of the more enriched source), which would account for the differing $\mathrm{Zr} / \mathrm{Ce}$ and $\mathrm{La} / \mathrm{Nb}$ ratios and incompatible-element levels.

3. Megagroup C (phenocrysts: minor clinopyroxene and plagioclase). The internal chemistry of this megagroup is not markedly influenced by clinopyroxene fractionation, since $\mathrm{Cr}$ is essentially constant and $\mathrm{Sc}$ actually increases with $\mathrm{Zr}$ content (Fig. 12). Olivine has not been recognized as a phenocryst phase, except that its influence is suggested by an irregular decrease in $\mathrm{Ni}$. On the other hand, Sr shows a decreasing trend with increasing $\mathrm{Zr}$, suggesting that plagioclase is the major fractionating phase, as it is actually observed to be in the basalts. The $\mathrm{Zr} / \mathrm{Ce}, \mathrm{La} / \mathrm{Nb}$, and $\mathrm{P}_{2} \mathrm{O}_{5} / \mathrm{Ce}$ ratios, as well as the levels of stable incompatible elements (Figs. 9 and 14 and Table 8), are different from those of the preceding megagroups, and probably indicate a slightly lightREE-enriched source compared with that of megagroups $\mathrm{A}$ and $\mathrm{B}$.

If the least evolved basalts of megagroups $\mathrm{A}$ and $\mathrm{B}$ represent, or approximate, "parental" compositions, then the only major difference between them is that the megagroup A "parent" has higher $\mathrm{Cr}$ and $\mathrm{Ni}$, and a correspondingly lower $\mathrm{FeO}^{*} / \mathrm{MgO}$ ratio, whereas incompatible-element abundances are only marginally lower. Variation in siderophile-element abundances indicates that the "parental" magmas could be related via high-pressure mafic fractionation before their subsequent low-pressure evolution in separate magma chambers. However, the similarity of Sc contents in the supposed initial compositions precludes extensive high-pressure pyroxene fractionation, even though $\mathrm{Cr}$ is variable. It seems more likely that the parental magmas were related (if at all) via minor high-pressure olivine fractionation. The uniformity of $\mathrm{Zr} / \mathrm{Y}$ ratios between the "parental" compositions rules out their generation by different degrees of partial melting, and the source also appears essentially homogenous in terms of similar $\mathrm{La} / \mathrm{Nb}$ and $\mathrm{Ce} / \mathrm{P}_{2} \mathrm{O}_{5}$ ratios. Another possibility that has not been fully explored, however, is that the two "parental" compositions reflect variable degrees of magma mixing of a more primitive melt (with higher Ni content) and a more evolved melt (relatively lower $\mathrm{Ni}$ ), the latter of which again implies olivine fractionation relative to the former.

\section{Trace-Element Fine Structure within the Chemical Megagroups}

Notwithstanding the limited compositional range shown by most trace elements within the megagroups, 
Table 7. Average chemical compositions of Nauru Basin sheet-flow basalts (Legs 89 and 61 compilations), various MORB types, and Hawaiian tholeiite.

\begin{tabular}{|c|c|c|c|c|c|c|c|c|c|}
\hline & \multicolumn{3}{|c|}{$\begin{array}{c}1 \\
\text { Leg } 89\end{array}$} & \multirow{2}{*}{$\underset{\bar{x}}{2}{ }^{2} 61$} & \multirow{2}{*}{$\begin{array}{c}3 \\
\text { N-type } \\
\text { MORB }\end{array}$} & \multirow{2}{*}{$\begin{array}{c}4 \\
\text { T-type } \\
\text { MORB }\end{array}$} & \multirow{2}{*}{$\begin{array}{c}5 \\
\text { P-type } \\
\text { MORB }\end{array}$} & \multirow{2}{*}{$\begin{array}{c}{ }^{6} \\
\text { Hawaiian } \\
\text { tholeiite }\end{array}$} & \multirow{2}{*}{$\begin{array}{c}7 \\
\text { Chondrite } \\
\text { average }\end{array}$} \\
\hline & $\bar{x}$ & S.d. & Range & & & & & & \\
\hline $\mathrm{SiO}_{2}$ & 50.17 & 0.69 & $47.44-51.52$ & 49.39 & 4.98 & 48.15 & 49.01 & 49.23 & \\
\hline $\mathrm{TiO}_{2}$ & 1.25 & 0.05 & $1.15-1.34$ & 0.99 & 1.67 & 1.76 & 3.02 & 2.50 & $620^{\mathrm{a}}$ \\
\hline $\mathrm{Al}_{2} \mathrm{O}_{3}$ & 13.90 & 0.26 & $12.89-14.51$ & 13.96 & 16.0 & 13.59 & 14.04 & 13.93 & - \\
\hline $\mathrm{Fe}_{2} \mathrm{O}_{3}$ & 4.08 & 0.47 & $3.18-6.60$ & - & 2.0 & 4.10 & 6.43 & 3.09 & - \\
\hline $\mathrm{FeO}$ & 8.82 & 0.50 & $6.74-9.74$ & 11.28 & 7.5 & 7.25 & 7.84 & 8.52 & - \\
\hline $\mathrm{MnO}$ & 0.22 & 0.03 & $0.14-0.46$ & 0.20 & 0.18 & 0.18 & 0.24 & 0.16 & - \\
\hline $\mathrm{MgO}$ & 6.73 & 0.28 & $6.05-7.82$ & 7.84 & 7.5 & 7.74 & 5.46 & 8.40 & - \\
\hline $\mathrm{CaO}$ & 11.37 & 0.44 & $9.02-11.92$ & 11.94 & 11.2 & 11.89 & 9.82 & 10.35 & - \\
\hline $\mathrm{Na}_{2} \mathrm{O}$ & 2.46 & 0.21 & $1.81-3.51$ & 2.06 & 2.8 & 2.12 & 2.78 & 2.16 & - \\
\hline $\mathrm{K}_{2} \mathrm{O}$ & 0.16 & 0.09 & $0.12-0.57$ & 0.07 & 0.13 & 0.29 & 0.48 & 0.38 & $120^{\mathrm{a}}$ \\
\hline $\mathrm{P}_{2} \mathrm{O}_{5}$ & 0.10 & 0.01 & $0.09-0.11$ & - & 0.15 & 0.20 & 0.39 & 0.26 & $46^{\mathrm{a}}$ \\
\hline $\mathrm{H}_{2}^{-} \mathrm{O}^{+}$ & 1.17 & 0.88 & $0.54-6.16$ & 1.49 & 0.21 & 1.16 & 1.52 & 0.61 & - \\
\hline $\mathrm{CO}_{2}$ & 0.05 & 0.08 & $0.02-0.51$ & 0.43 & 0.13 & 0.21 & 0.12 & 0.10 & - \\
\hline $\mathrm{Ba}$ & 13 & 10 & $5-44$ & 10 & 12 & 56 & 96 & 202 & 6.9 \\
\hline $\mathrm{Ce}$ & 13 & 4 & $6-24$ & 8 & 9 & 22 & 42 & 31 & 0.865 \\
\hline $\mathrm{Cr}_{\mathrm{r}}$ & 149 & 14 & $115-179$ & 303 & 393 & 235 & 46 & 269 & - \\
\hline La & 5 & 1 & $3-8$ & 3 & 3 & 13 & 19 & 12 & 0.328 \\
\hline $\mathrm{Nb}$ & 5 & 0.7 & $4-8$ & - & 3 & 13 & 29 & 14 & 0.35 \\
\hline $\mathrm{Nd}$ & 10 & 2 & $5-16$ & - & 8 & 14 & 25 & 21 & 0.63 \\
\hline $\mathrm{Ni}$ & 82 & 5 & 66-91 & 115 & 146 & 89 & 32 & 126 & - \\
\hline $\mathrm{Rb}$ & 4 & 2 & $2-9$ & 7 & 1 & 4 & 8 & 8 & 0.35 \\
\hline Sc & 46 & 2 & $40-51$ & 46 & 44 & 43 & 39 & 31 & 7.9 \\
\hline $\mathrm{Sr}$ & 110 & 3 & $103-122$ & 99 & 124 & 143 & 269 & 350 & 11.8 \\
\hline Y & 29 & 3 & $22-33$ & 26 & 33 & 31 & 44 & 26 & 2.0 \\
\hline $\mathrm{Zr}$ & 64 & 5 & $55-78$ & 79 & 100 & 108 & 213 & 161 & 6.84 \\
\hline $\mathrm{Ti} / \mathrm{Zr}$ & 118 & & & 75 & 100 & 98 & 85 & 93 & 91 \\
\hline $\mathrm{La} / \mathrm{Nb}$ & 1.0 & & & - & 1.0 & 1.0 & 0.7 & 0.9 & 0.9 \\
\hline $\mathrm{P}_{2} \mathrm{O}_{5} / \mathrm{Ce}$ & 77 & & & - & 167 & 91 & 93 & 84 & 122 \\
\hline $\mathrm{TiO}_{2} / \mathrm{P}_{2} \mathrm{O}_{5}$ & 12.5 & & & - & 11.1 & 8.8 & 7.7 & 9.6 & 9.8 \\
\hline $\mathrm{Zr} / \mathrm{Nb}$ & 12.8 & & & - & 33.3 & 8.3 & 7.3 & 11.5 & 19.5 \\
\hline $\mathrm{Ti} / \mathrm{Y}$ & 259 & & & 228 & 304 & 341 & 412 & 576 & 310 \\
\hline $\mathrm{Zr} / \mathrm{Y}$ & 2.2 & & & 3.0 & 3.0 & 3.5 & 4.8 & 6.2 & 3.4 \\
\hline
\end{tabular}

Note: References: 1 -this work (75 samples); 2 -compilation calculated from data in Larson, Schlanger, et al. (1981) 3-averages from Condie (1976, major elements), Delaney et al. (1978, $\left.\mathrm{H}_{2} \mathrm{O}+\mathrm{CO}_{2}\right)$, Sun and Nesbitt (1977) and Sun et al. (1979), trace elements, $\mathrm{TiO}_{2}, \mathrm{~K}_{2} \mathrm{O}, \mathrm{P}_{2} \mathrm{O}_{5} ; 4$-compiled average for Reykjanes Ridge, DSDP Holes 407 408, and 409 (Tarney et al., 1979 + Appendix IV; Floyd and Tarney, 1979); 5-compiled average for E. Iceland Tertiary upper lava group (Flower et al., 1982; Gibson et al., 1982); 6-compiled average for Hawaiian tholeiites (Macdonald and Katsura, 1964; Easton and Garcia, 1980; Leeman et al. 1980; Schilling and Winchester 1969); 7-values from Thompson (1982), based partly on Sun and Nesbitt (1977). - = no data.

${ }^{\mathrm{a}} \mathrm{Ti}, \mathrm{K}$, and $\mathrm{P}$ values as elements in ppm.

small but sharp jumps in abundance and reversals in systematic trends do occur with depth (Fig. 9). This allows the basalt flows to be divided into small chemical subgroups ( 22 in all), each of which is apparently composed of internally related members. These features are similar to those seen in many MOR sections (e.g., Flower et al., 1977; Natland, 1979b), although here the cyclicity of chemical groups, and their variation, are much more subdued. How significant these subgroup variations are is difficult to say, but two possible genetic models are suggested: (1) post-magma-chamber fractionation, and (2) magma mixing within a replenished magma chamber. Support for the first suggestion comes from the fact that the most primitive composition of each subgroup (within any megagroup) could be related via mafic fractionation, with the possible exception of the subgroups in phyric Units 49 to 51 . It is tentatively suggested that this relationship could occur after initial low-pressure fractionation within the parent magma chamber, with separate magma pulses expelled undergoing further minor fractionation (or flow differentiation) as they rose toward the ocean floor. The two generations of clinopyroxene phenocrysts observed in many basalts lend some support to this, in that the glomerocrysts probably crystallized within the magma chamber, whereas the isolated granular microphenocrysts (on which variolitic clinopyroxene is nucleated) crystallized on route in feeder channels near the surface. On the other hand, a more likely (and preferred) model is that the "sawtooth" subgroup variation represents magma mixing between a continuously fractionating stored magma and influxes of new magma from below (cf. O'Hara and Mathews, 1981). Each subgroup represents the eruption of a variably fractionated magma batch, and the chemical jump to a new subgroup indicates replenishment of the magma chamber by new melt of generally more primitive composition.

\section{DISCUSSION AND CONCLUSIONS}

1. Leg 89 intraplate basalts represent a series of rapidly extruded sheet-flows composed of thin, interlayered aphyric and poorly clinopyroxene-plagioclase-olivine phyric, olivine- to quartz-normative tholeiites. Twelve volcanic units have been recognized on the basis of observable contacts and textural and lithologic variation. All 

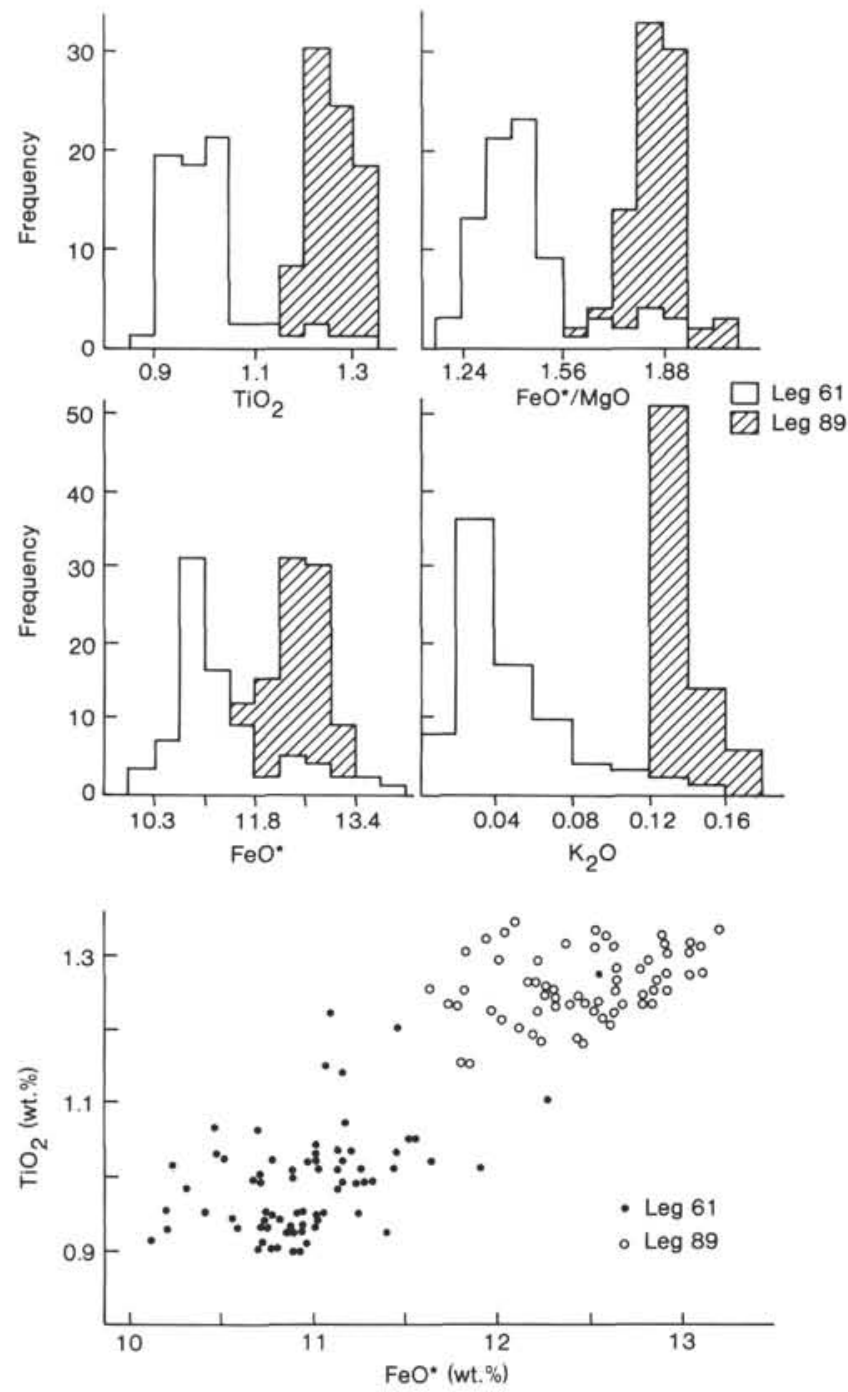

Figure 8. Comparison of $\mathrm{TiO}_{2}, \mathrm{~K}_{2} \mathrm{O}, \mathrm{FeO}^{*}$, and $\mathrm{FeO} * / \mathrm{MgO}$ distributions in Leg 61 (data taken from Larson, Schlanger, et al., 1981) and Leg 89 (this work) samples.

the units are essentially nonvesicular, or if vesicles are present they are very small and indicate extrusion under very deep water. The basalts exhibit only mild hydrous and oxidative alteration effects under reducing, low- $\mathrm{CO}_{2}$-activity conditions, during low-temperature reaction with cold seawater. Secondary assemblages are dominated by various smectites, zeolites, pyrite, with minor celadonite, K-feldspar, albite, and quartz, all developed under zeolite-facies conditions. Glass is invariably replaced by palagonite and/or brown smectite. No systematic chemical changes in alteration intensity relative to depth are exhibited.

2. Chemically the basalts are remarkably uniform throughout, with low incompatible-element abundances, but are moderately evolved as regards primary compositions (having low $\mathrm{Mg}$ numbers) and their high total $\mathrm{Fe}$. These apparently opposing chemical features probably reflect a low incompatible-element source coupled with a relatively high degree of fractionation soon after melt segregation. A high proportion of the samples have chemical ( $>12$ wt. \% FeO*) and mineralogical (paucity of ol- ivine; clinopyroxene-plagioclase glomerocrysts) features typical of ferrobasalts from Pacific Ocean rifts (e.g., Galapagos Rift and EPR; Natland, 1980), although incompatible elements are by comparison generally low at specific $\mathrm{FeO}^{*}$ levels. Models for the generation of ferrobasalts associated with fast-spreading ridges indicate high degrees of low-pressure fractionation $(\sim 74 \%$ of parental magma) in flat-topped, laterally extensive, isolated, unreplenished magma chambers (Clague and Bunch, 1976; Natland, 1980). The regionally extensive nature of submarine sheet-flows in the Nauru Basin, and their isolation from spreading ridges during the Cretaceous, preclude a direct tectonic comparison of these ferrobasalts. Ferrobasalts are also commonly associated with Icelandic tholeiites, and form part of a progressively fractionated lineage from more primitive compositions (Wood, 1978). However, although $\mathrm{FeO}^{*}$ values are comparable, Icelandic ferrobasalts are more chemically evolved than the Nauru Basin rocks, and exhibit higher FM values $\left(\mathrm{FeO}^{*}+\mathrm{MnO} / \mathrm{FeO}^{*}+\mathrm{MnO}+\mathrm{MgO}=74\right.$ to 77$)$ and incompatible-element abundances (e.g., $\mathrm{TiO}_{2} 3.5-4.0$ wt. $\%$ ) and lower $\mathrm{MgO}$ contents of between 4 and 5 wt. \% (Wood, 1978; Flower et al., 1982). By comparison, the Nauru Basin ferrobasalts appear to have had a different genesis or to have been derived from a source-composition different from that of ridge-associated Fe-rich basalts.

3. Comparison of average chemical compositions (Table 7; Fig. 15) indicates that, overall, the Nauru Basin basalts are only mildly enriched in the highly incompatible elements, compared with N-type MORB. Many incompatible-element ratios $\left(\mathrm{Th} / \mathrm{U}, \mathrm{La} / \mathrm{Nb}, \mathrm{P}_{2} \mathrm{O}_{5} / \mathrm{Ce}\right.$, $\mathrm{TiO}_{2} / \mathrm{P}_{2} \mathrm{O}_{5}, \mathrm{Ti} / \mathrm{Zr}, \mathrm{Zr} / \mathrm{Nb}, \mathrm{Ti} / \mathrm{Y}, \mathrm{Zr} / \mathrm{Y}$ ) have values generally lower than or close to chondritic. A mildly LILdepleted, MORB-like, approximately chondritic source for the basalts is suggested. It seems unlikely that the minor enhancement of $\mathrm{Ba}, \mathrm{K}, \mathrm{Rb}, \mathrm{Th}$, etc., relative to $\mathrm{N}-\mathrm{MORB}$, is a reflection of alteration-enrichment, because this feature is typical of the vast majority of the basalts, including the least altered. Whether or not the intraplate basalts were contaminated by highly altered, LIL-enriched Jurassic ocean crust, through which the magmas must have passed, is difficult to assess. Sr-isotope data for Leg 61 basalts (Fujii et al., 1981) are uniform but marginally higher $(0.7037)$ than $\mathrm{N}$-type MORB, and could equally reflect minor differences in source or ${ }^{87} \mathrm{Sr}$ contamination by Jurassic MORB enriched by seawater alteration. Possible contamination aside, the Nauru Basin intraplate sheet-flows are similar to mildly enriched types of MORB (e.g., Reykjanes Ridge, Fig. 15).

Chemical discrimination of the tectonic environment, using either major or trace elements, gives disparate results, with the Nauru Basin intraplate basalts plotting in island-arc, or straddling island-arc, MORB fields (Fig. 16). Clearly, if basalts similar to these were now found in a tectonically complex setting on continental crust, chemical discrimination of the environment would be erroneous and would probably designate them as MORBthat is, plate-margin rather than intraplate.

4. Although the basalts are characterized by a general uniformity of composition, as already stated, variations do occur which allow them to be divided, on the 
PETROLOGY AND GEOCHEMISTRY

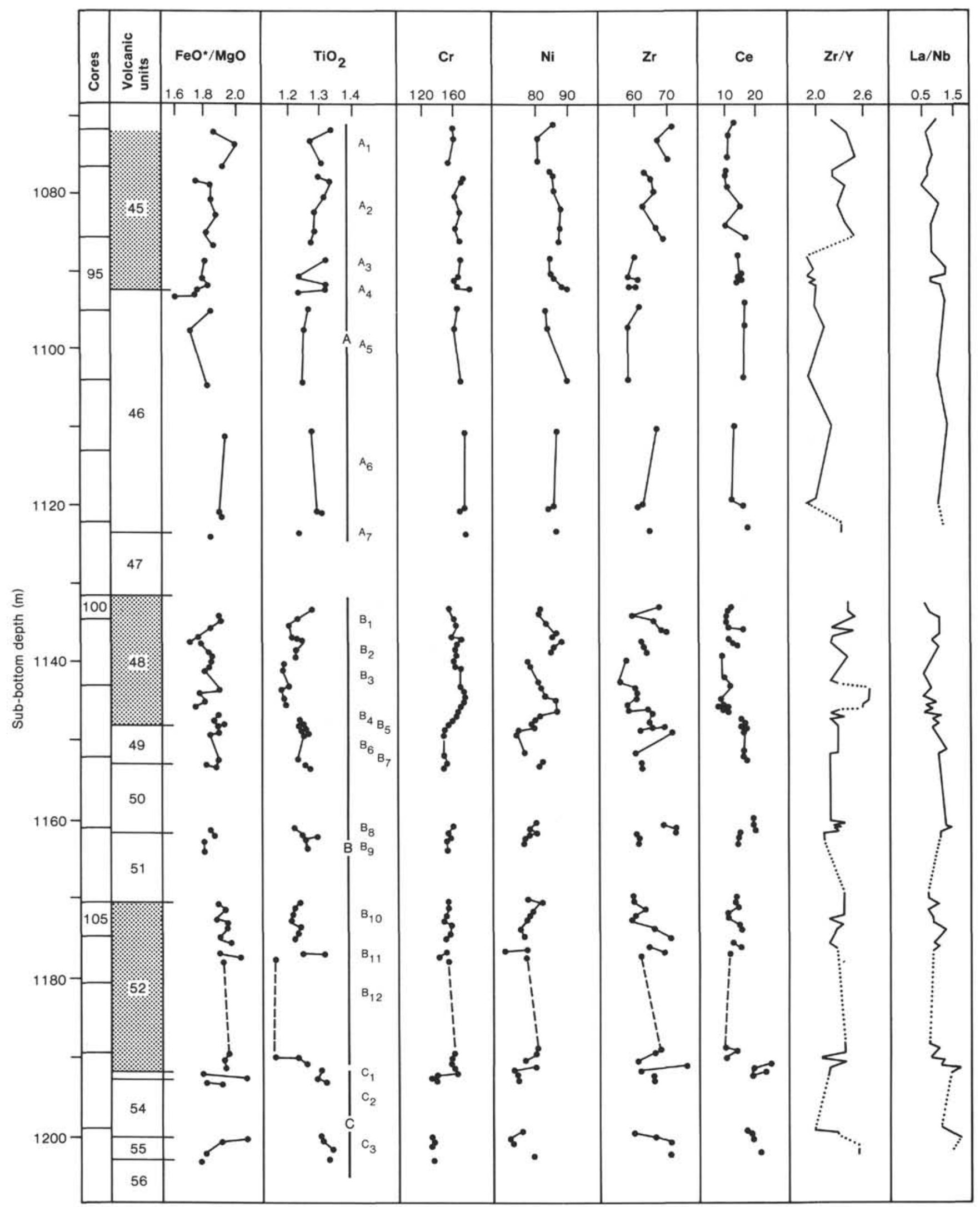

Figure 9. Chemical stratigraphy in Hole 462A (Leg 89), showing the distribution of the megagroups A, B, and C and various subgroups with depth. 


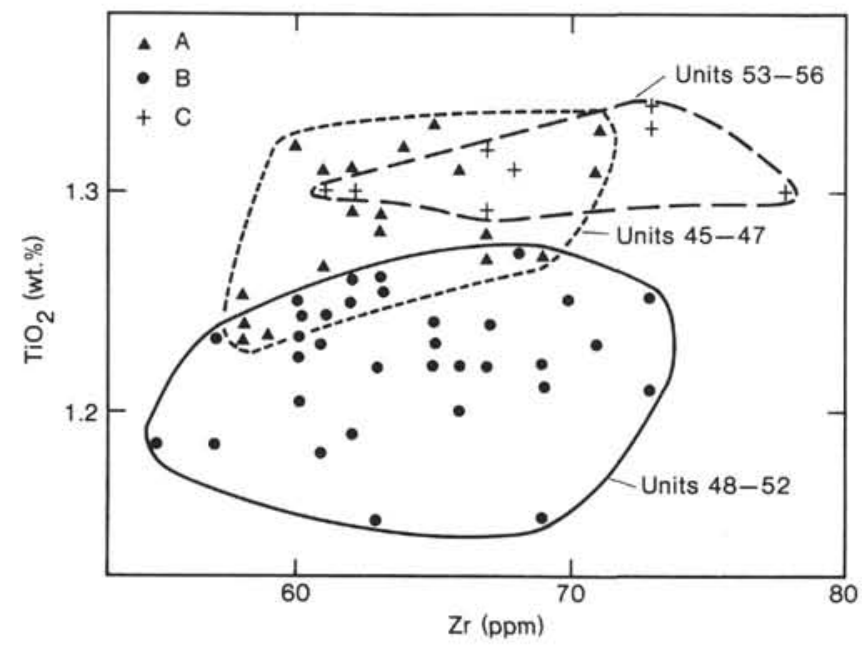

Figure 10 . $\mathrm{TiO}_{2}-\mathrm{Zr}$ plot of Hole $462 \mathrm{~A}$ (Leg 89 ) basalts showing the division of the volcanic units into three chemical megagroups A, B, and $\mathrm{C}$.

basis of $\mathrm{TiO}_{2}$ content, into three chemical megagroups (A, B, C) with depth. Each megagroup is conceived as representing a high-level magma chamber that stores magma for variable periods before eruption. The eruptive stratigraphy developed reflects the progressive fractional crystallization of such magma bodies, together with mixing caused by the influx of more primitive magma at the base.

In general, aphyric and poorly phyric volcanic units within the megagroups overlap in chemical composition, the various basalts being related via mafic and/or plagioclase fractionation. The small range of chemical variation, the lack of cumulates, and the generally low proportion of observed phenocrysts in any megagroup suggest that the magma chambers were probably small and short-lived, such that extensive fractionation did not take place. Also, if eruption is related to replenishment of the chamber by new magma batches from below (Sparks et al., 1980), then rapid extrusion implies a semicontinuous supply of new magma and consequently the opportunity of magma mixing (O'Hara and Mathews, 1981) that periodically interrupts the fractionation process. In such a process the extrusive stratigraphy would be expected to show a number of small chemical breaks between eruptive units derived from such a magma chamber. The more frequent or larger the replenishment, the smaller the chemical variation might be, especially if density differences between stored and injected melts were minor and mixing could readily occur. As shown in the

Table 8. Mean and standard deviation (s. d.) of chemical megagroups A, B, and C in Nauru Basin basaltic sheet-flows, Hole 462A (major oxides in wt. \%, trace elements in ppm).

\begin{tabular}{|c|c|c|c|c|c|c|}
\hline & \multicolumn{6}{|c|}{$\begin{array}{l}\text { Chemical groups } \\
\text { (volcanic units; no. of samples) }\end{array}$} \\
\hline & \multicolumn{2}{|c|}{$\frac{\mathrm{A}}{(45,46,47 ; 22 \text { samples })}$} & \multicolumn{2}{|c|}{$\underset{(48,49,50,51,52 ; 45 \text { samples })}{\text { B }}$} & \multicolumn{2}{|c|}{$\begin{array}{c}\mathrm{C} \\
(53,54,55,56 ; 8 \text { samples })\end{array}$} \\
\hline & Mean & S. d. & Mean & S. d. & Mean & S. d. \\
\hline $\mathrm{SiO}_{2}$ & 49.93 & 0.52 & 50.31 & 0.80 & 49.91 & 0.29 \\
\hline $\mathrm{TiO}_{2}$ & 1.28 & 0.03 & 1.22 & 0.04 & 1.31 & 0.02 \\
\hline $\mathrm{Al}_{2} \mathrm{O}_{3}$ & 13.95 & 0.24 & 13.87 & 0.27 & 13.91 & 0.27 \\
\hline $\mathrm{Fe}_{2} \mathrm{O}_{3}$ & 4.10 & 0.65 & 4.00 & 0.36 & 4.48 & 0.15 \\
\hline $\mathrm{FeO}$ & 8.98 & 0.67 & 8.79 & 0.38 & 8.55 & 0.49 \\
\hline $\mathrm{MnO}$ & 0.22 & 0.06 & 0.21 & 0.02 & 0.22 & 0.02 \\
\hline $\mathrm{MgO}$ & 6.90 & 0.29 & 6.65 & 0.24 & 6.69 & 0.29 \\
\hline $\mathrm{CaO}$ & 11.34 & 0.63 & 11.39 & 0.33 & 11.32 & 0.38 \\
\hline $\mathrm{Na}_{2} \mathrm{O}$ & 2.41 & 0.17 & 2.44 & 0.16 & 2.69 & 0.38 \\
\hline $\mathrm{K}_{2} \mathrm{O}$ & 0.16 & 0.09 & 0.16 & 0.09 & 0.13 & 0.05 \\
\hline $\mathrm{P}_{2} \mathrm{O}_{5}$ & 0.11 & 0.01 & 0.10 & 0.005 & 0.11 & 0.01 \\
\hline $\mathrm{H}_{2} \mathrm{O}^{+}$ & 0.99 & 0.49 & 1.25 & 1.07 & 1.24 & 0.19 \\
\hline $\mathrm{CO}_{2}$ & 0.12 & 0.11 & 0.03 & 0.03 & 0.03 & 0.01 \\
\hline Total & 100.49 & & 100.42 & & 100.59 & \\
\hline $\mathrm{Ba}$ & 15 & 10 & 12 & 10 & 14 & 12 \\
\hline $\mathrm{Ce}$ & 13 & 2 & 12 & 3 & 19 & 3 \\
\hline $\mathrm{Cr}$ & 164 & 5 & 146 & 8 & 123 & 11 \\
\hline $\mathrm{La}$ & 5 & 1 & 4 & 1 & 7 & 1 \\
\hline $\mathrm{Nb}$ & 5 & 1 & 5 & 0.6 & 5 & 1 \\
\hline Nd & 9 & 1 & 9 & 2 & 12 & 2 \\
\hline $\mathrm{Ni}$ & 86 & 3 & 81 & 4 & 76 & 3 \\
\hline $\mathrm{Rb}$ & 4 & 2 & 4 & 2 & 4 & 2 \\
\hline Sc & 43 & 2 & 46 & 2 & 48 & 1 \\
\hline $\mathrm{Sr}$ & 110 & 4 & 110 & 3 & 114 & 3 \\
\hline Y & 30 & 2 & 28 & 3 & 30 & 2 \\
\hline $\mathrm{Zr}$ & 64 & 4 & 64 & 5 & 69 & 6 \\
\hline $\mathrm{FeO} * / \mathrm{MgO}$ & 1.84 & & 1.86 & & 1.88 & \\
\hline $\mathrm{Ti} / \mathrm{Zr}$ & 120 & & 114 & & 114 & \\
\hline $\mathrm{Ti} / \mathrm{Y}$ & 256 & & 261 & & 262 & \\
\hline $\mathrm{Zr} / \mathrm{Y}$ & 2.13 & & 2.28 & & 2.30 & \\
\hline $\mathrm{La} / \mathrm{Nb}$ & 1.00 & & 0.80 & & 1.41 & \\
\hline $\mathrm{P}_{2} \mathrm{O}_{5} / \mathrm{Ce}$ & 84.6 & & 83.3 & & 57.9 & \\
\hline $\mathrm{TiO}_{2} / \mathrm{P}_{2} \mathrm{O}_{5}$ & 11.6 & & 12.2 & & 11.9 & \\
\hline
\end{tabular}



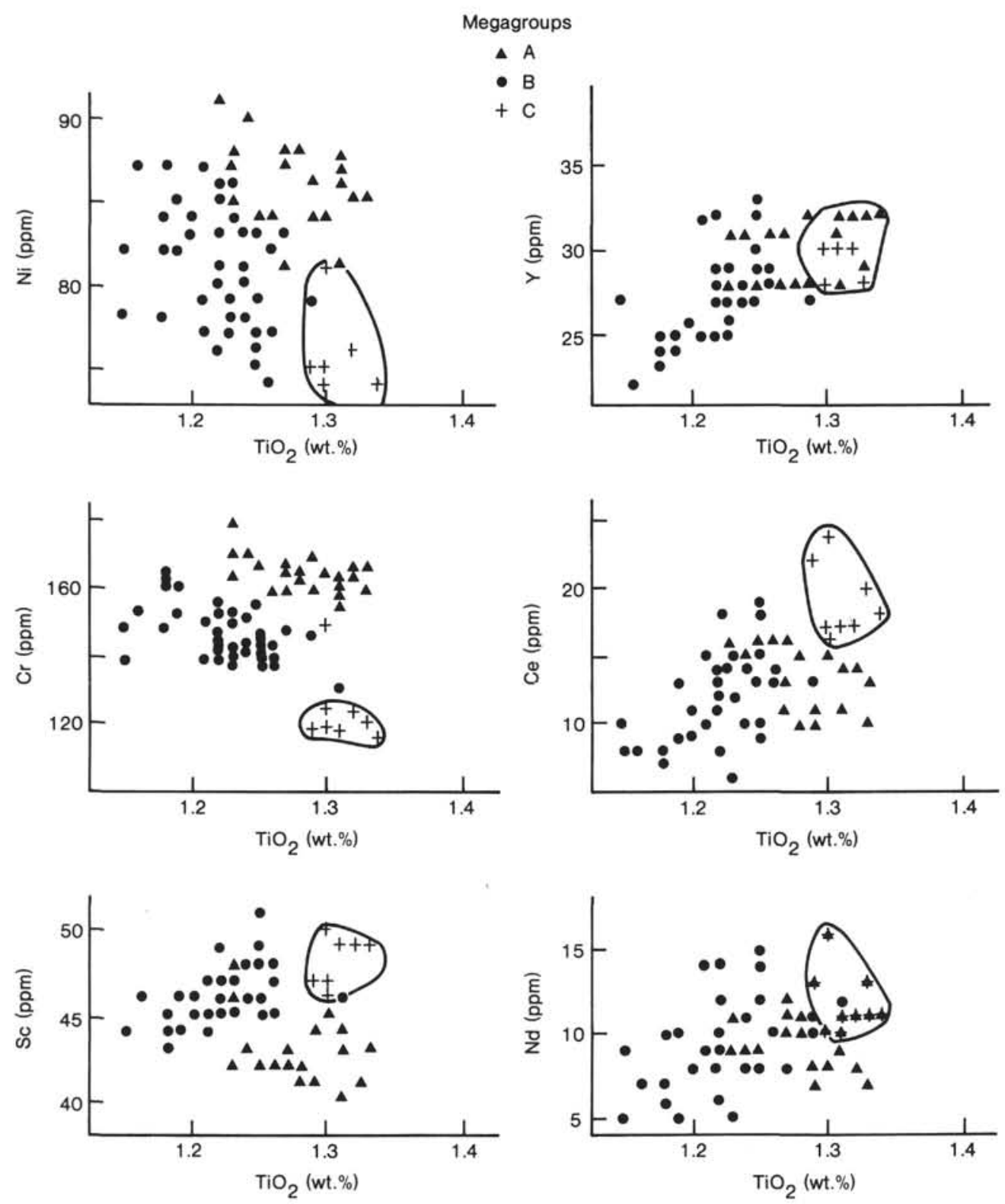

Figure 11. Distribution of various compatible and incompatible elements relative to $\mathrm{TiO}_{2}$ in chemical megagroups $\mathrm{A}, \mathrm{B}$, and $\mathrm{C}$.

preceding section, the megagroups can be divided into small chemical subgroups, the "sawtooth" variation of which probably reflects a mixing process. Some chemical subgroups show internal fractionation, whereas others are essentially uniform in composition and represent complete mixing with large quantities of new melt to a steady-state composition. In the previous section it was suggested that minor fractionation in the feeder conduits after expulsion from the magma chamber might also be responsible for the chemical subgroups. It seems more likely, however, that the small fluctuations in low- $\mathrm{K}_{D}$ element ratios throughout the pile are more satisfactorily explained on a magma-mixing model, whereas if fractionation were the only factor, such ratios would be constant for the megagroup as a whole.

In conclusion, the following magma plumbing system is envisaged. Magma originates by the relatively high, but uniform, partial melting of a MORB-like depleted mantle. On the basis of various low- $\mathrm{K}_{D}$ element ratios, there is some evidence to suggest minor differences in source composition, with a more LIL-enriched source (relative to $\mathrm{A}$ and $\mathrm{B}$ ) providing the initial melt for megagroup $\mathrm{C}$. The degree of melting is very similar, however, in both sources.

If the original magmas were in equilibrium with normal mantle peridotite (e.g., Frey et al., 1978), they must have undergone some olivine (and minor clinopyroxene) fractionation to produce three parental melts of variable siderophile- and incompatible-element contents that segregated in separate, small, high-level magma chambers. Variable internal fractionation takes place, such that all the flows originating from one chamber are grossly related via limited clinopyroxene-plagioclase-olivine precipitation. Extensive progressive fractionation is not 

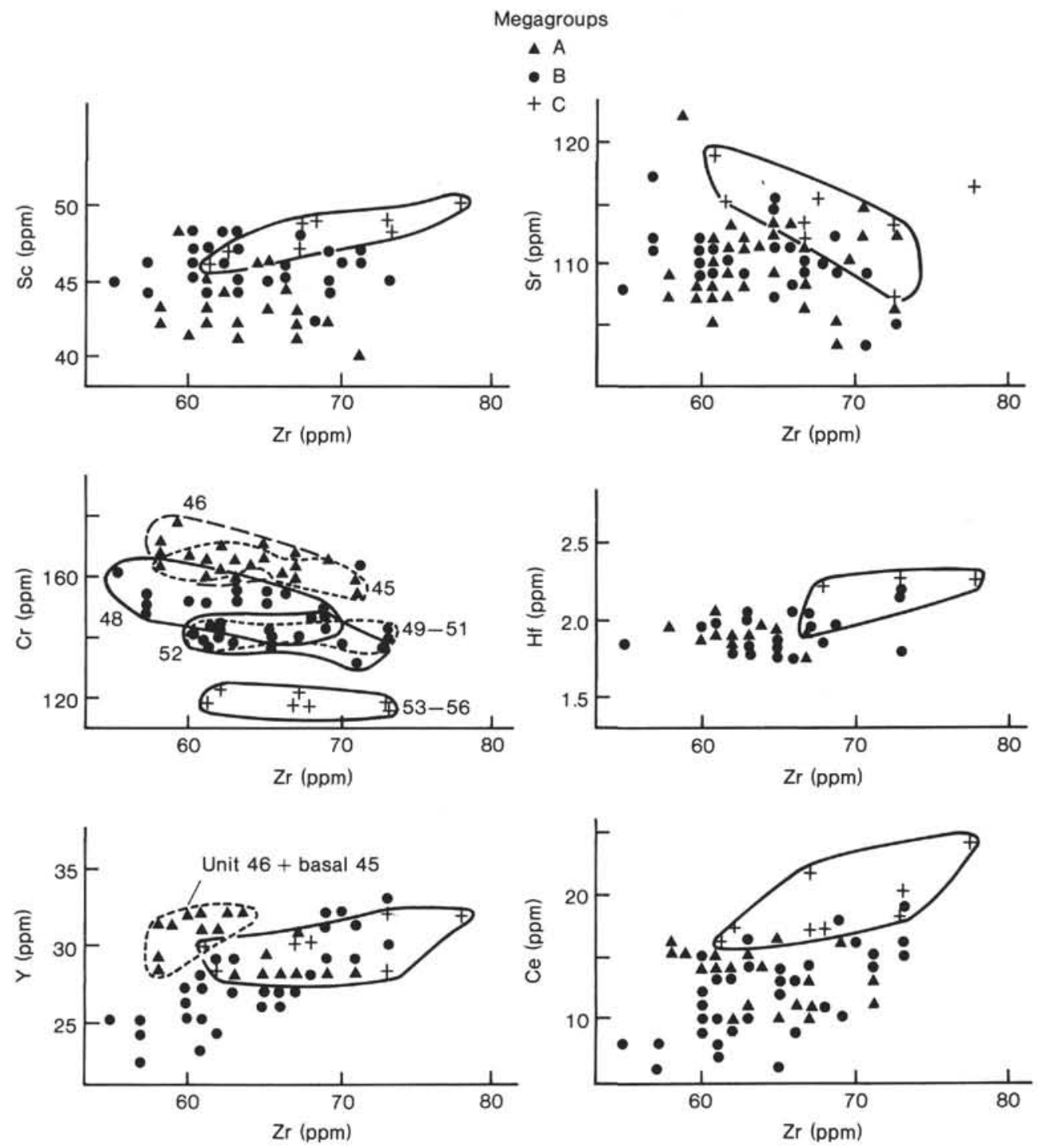

Figure 12. Distribution of various elements relative to progressive fractionation (as measured by $\mathrm{Zr}$ content) within the three chemical megagroups $\mathrm{A}, \mathrm{B}$, and $\mathrm{C}$.

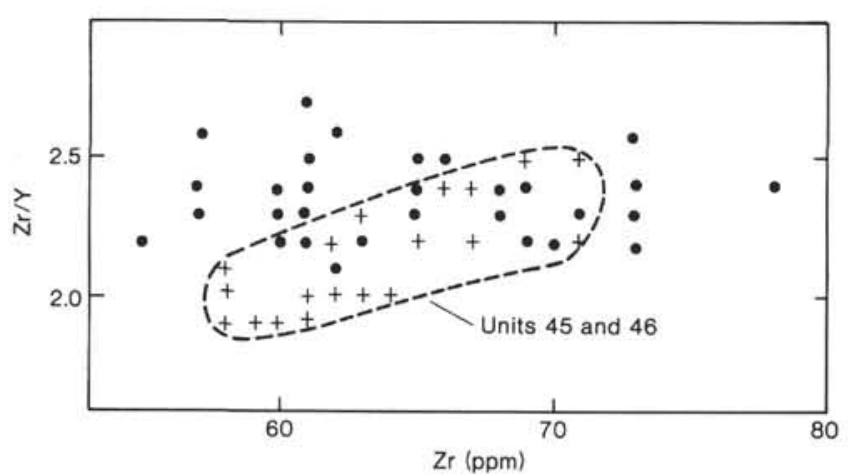

Figure 13. $\mathrm{Zr} / \mathrm{Y}-\mathrm{Zr}$ plot for Hole $462 \mathrm{~A}$ (Leg 89 ) basalts, showing the essentially constant $\mathrm{Zr} / \mathrm{Y}$ ratio for the majority of samples $(\bullet)$ relative to a progressive increase in Volcanic Units 45 and $46(+)$. Samples with $\mathrm{Zr} / \mathrm{Y}$ at about 2.6-2.7 correspond to the base of Unit 48 .

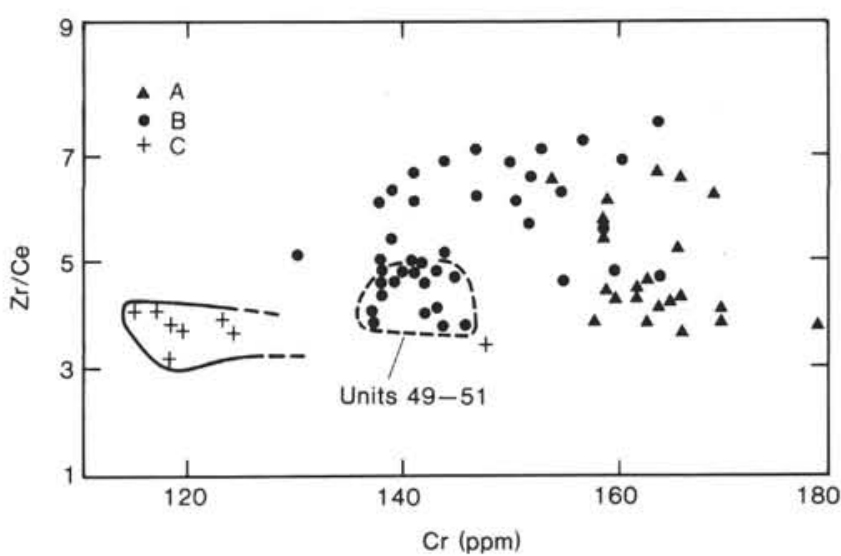

Figure 14. $\mathrm{Zr} / \mathrm{Ce}-\mathrm{Cr}$ plot for Hole $462 \mathrm{~A}$ (Leg 89) basalts, showing the separate clustering of the phyric Volcanic Units 49 to 51 relative to the rest of chemical megagroup B, and also the typically lower $\mathrm{Zr}$ / $\mathrm{Ce}$ ratio of chemical megagroup $\mathrm{C}$ relative to $\mathrm{A}$ and $\mathrm{B}$. 

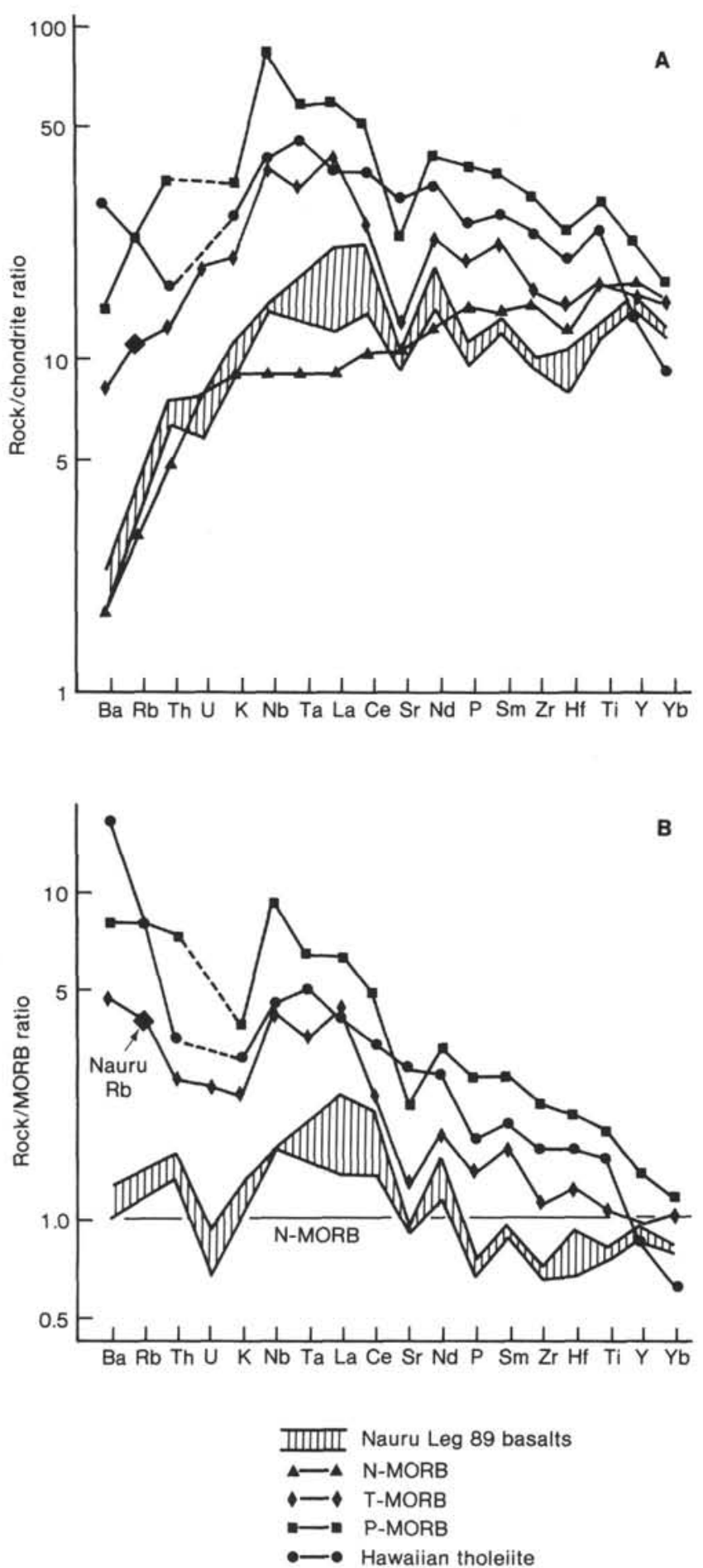

Figure 15. Spidergrams for MORB averages and Leg 89 basalts (megagroup averages enclosed within envelope) normalized relative to (A) chondrite abundances (factors from Thompson, 1982) and (B) N-type MORB (factors from Sun and Nesbitt, 1977). Comparative data taken from Table 7. The high normalized Rb-value for Leg 89 basalts is probably analytical.

achieved, however, owing to the frequent influx of new magma, produced by similar degrees of melting, that mixes with the stored magma. The magma chambers rapidly expel their melts, apparently in sequence, and were probably short-lived.

\section{ACKNOWLEDGMENTS}

Thanks are due many shipboard colleagues, especially Dr. S. O. Schlanger, Dr. R. Moberly, and Dr. J. Haggerty, for enlightening discussions on Pacific Cretaceous volcanology and tectonics. Technical help on Glomar Challenger - in thin-section preparation, photography, and running the HNC Analyser-were much appreciated. Involvement in DSDP/IPOD shipboard studies would not have been possible except for the continued support of the Natural Environmental Research Council, U.K., which is gratefully acknowledged. I thank David Emley and Margaret Aiken for their help and expertise in analyzing the samples. Dr. A. Saunders provided constructive criticism and helpful comment on this work, for which I am grateful. Dr. R. Batiza and Dr. J. Bender are also acknowledged for their reviews of this chapter.

\section{REFERENCES}

Andrews, A. J., Barnett, R. L., MacClement, B. A. E., Fyfe, W. S., Morrison, G., et al., 1977. Zeolite facies metamorphism, geochemistry and some aspects of trace element redistribution in altered basalts of DSDP Leg 37. In Aumento, F., Melson, W. G., et al., Init. Repts. DSDP, 37: Washington (U.S. Govt. Printing Office), 795-810.

Barringer, A. R., 1953. The preparation of polished sections of ores and mill products using diamond abrasives and their quantitative study by point counting methods. Trans. Am. Inst. Min. Metall. Engr., 63:26-41.

Batiza, R., 1981. Trace-element characteristics of Leg 61 basalts. In Larson, R. L., Schlanger, S. O., et al., Init. Repts. DSDP, 61: Washington (U.S. Govt. Printing Office), 689-696.

Batiza, R., Larson, R. L., Schlanger, S. O., Shcheka, S. A., and Tokuyama, H., 1980. Trace element abundances in basalts of the Nauru Basin. Nature (London), 286:476-478.

Brooks, C., 1976. The $\mathrm{Fe}_{2} \mathrm{O}_{3} / \mathrm{FeO}$ ratio of basalt analyses: An appeal for a standardized procedure. Bull. Geol. Soc. Denmark, 25: 117-120.

Clague, D. A., and Beeson, M. H., 1980. Trace element geochemistry of the East Molokai Volcanic Series, Hawaii. Am. J. Sci., 280A: 820-844.

Clague, D. A., and Bunch, T. E., 1976. Formation of ferrobasalt at east Pacific midocean spreading centres. J. Geophys. Res., 81: 4247-4256.

Condie, K. C., 1976. Trace element geochemistry of Archaean greenstone belts. Earth-Sci. Rev., 12:393-417.

Delaney, J. R., Muenow, D. W., and Graham, D. G., 1978. Abundance and distribution of water, carbon and sulfur in the glassy rims of submarine pillow lavas. Geochim. Cosmochim. Acta, 42: 581-594.

Duffield, J., and Gilmore, G. R., 1979. An optimum method for the determination of rare earth elements by neutron activation analysis. J. Radioanal. Chem., 48:135-145.

Easton, R. M., and Garcia, M. O., 1980. Petrology of the Hilina Formation, Kilauea Volcano, Hawaii. Bull. Volcanol., 43:657-673.

Flower, M. F. J., Pritchard, R. G., Brem, G., Cann, J. R., Delaney, J., et al., 1982. Chemical stratigraphy, Iceland Research Drilling Project Reydarfjordur, eastern Iceland. J. Geophys. Res., 87:6489-6510.

Flower, M. F. J., Robinson, P. T., Schmincke, H.-U., and Ohnmacht, W., 1977. Petrology and geochemistry of igneous rocks, DSDP Leg 37. In Aumento, F., Melson, W. G., et al., Init. Repts. DSDP, 37: Washington (U.S. Govt. Printing Office), 653-679.

Floyd, P. A., and Fuge, R., 1982. Primary and secondary alkali and halogen element distribution in Iceland Research Drilling Project basalts from eastern Iceland. J. Geophys. Res., 87:6477-6488.

Floyd, P. A., and Tarney, J., 1979. First-order alteration chemistry of Leg 49 basement rocks. In Luyendyk, B. P., Cann, J. R., et al., Init. Repts. DSDP, 49: Washington (U.S. Govt. Printing Office), 693-708.

Frey, F. A., Green, D. H., and Roy, S. D., 1978. Integrated models of basalt petrogenesis: A study of quartz tholeiites to olivine melilitites from southeastern Australia utilizing geochemical and experimental petrological data. J. Petrol., 19:463-513.

Fujii, N., Notsu, K., and Onuma, N., 1981. Chemical composition and $\mathrm{Sr}$ isotopes of Deep Sea Drilling Project Leg 61 basalts. In Larson, R. L., Schlanger, S. O., et al., Init. Repts. DSDP, 61: Washington (U.S. Govt. Printing Office), 697-700. 
Gibson, I. L., Kirkpatrick, R. J., Emmerman, R., Schmincke, H.-U., Pritchard, G., et al., 1982. The trace element composition of the lavas and dikes from a $3-\mathrm{km}$ vertical section through the lava pile of eastern Iceland. J. Geophys. Res., 87:6532-6546.

Haggerty, J. A., Schlanger, S. O., and Premoli Silva, I., 1982. Late Cretaceous and Eocene volcanism in the southern Line Islands and implications for hotspot theory. Geology, 10:433-437.

Hart, S. R., and Davis, K. E., 1978. Nickel partitioning between olivine and silicate melt. Earth Planet. Sci. Lett., 40:203-219.

Hart, S. R., Erlank, A. J., and Kable, E. J. D., 1974. Sea floor basalt alteration: Some chemical and $\mathrm{Sr}$ isotopic effects. Contrib. Mineral. Petrol., 44:219-230.

Hart, S. R., and Nalwalk, A. J., 1970. K, Rb, Cs and Sr relationships in submarine basalts from the Puerto Rico Trench. Geochim. Cosmochim. Acta., 34:145-156.

Hilde, T. W. C., Uyeda, S., and Kroenke, L., 1977. Evolution of the western Pacific and its margins. Tectonophysics, 38:145-165.

Humphris, S. E., and Thompson, G., 1978. Hydrothermal alteration of oceanic basalts by seawater. Geochim. Cosmochim. Acta, 42: 107-126.

Humphris, S. E., Thompson, R. N., Gibson, I. L., and Marriner, G. F., 1980. Comparison of geochemistry of basalts from the East Pacific Rise, OCP Ridge and Siqueiros Fracture Zone, Deep Sea Drilling Project, Leg 54. In Rosendahl, B. R., Hekinian, R., et al., Init. Repts. DSDP, 54: Washington (U.S. Govt. Printing Office), 635-669.

Humphris, S. E., Thompson, R. N., and Marriner, G. F., 1980. The mineralogy and geochemistry of basalt weathering, Holes 417A and 418A. In Donnelly, T., Francheteau, J., Bryan, W., Robinson, P., Flower, M., Salibury, M., et al., Init. Repts. DSDP, 51, 52, 53, Pt. 2: Washington (U.S. Govt. Printing Office), 1201-1218.

Kirkpatrick, R. J., 1979. Process of crystallization in pillow basalts, Hole 396B, DSDP Leg 46. In Dmitriev, L., Heirtzler, J., et al., Init. Repts. DSDP, 46: Washington (U.S. Govt. Printing Office), 271-282.

Kurnosov, V. B., Kholodkevich, I. V., and Ya Shevchenko, A., 1981. Secondary minerals of basalts from the Nauru Basin, Deep Sea Drilling Project, Leg 61. In Larson, R. L., Schlanger, S. O., et al., Init. Repts. DSDP, 61: Washington (U.S. Govt. Printing Office), 653-671.

Larson, R. L., 1976. Late Jurassic and Early Cretaceous evolution of the western central Pacific ocean. J. Geomag. Geoelectr., 28: 219-236.

Larson, R. L., and Schlanger, S. O., 1981. Geological evolution of the Nauru Basin and regional implications. In Larson, R. L., Schlanger, S. O., et al., Init. Repts. DSDP, 61: Washington (U.S. Govt. Printing Office), 841-862.

Larson, R. L., Schlanger, S. O., et al., 1981. Init. Repts. DSDP, 61: Washington (U.S. Govt. Printing Office).

Leake, B. E., Hendry, G. L., Kemp, A., Plant, A. G., Harvey, P. K., et al., 1969. The chemical analysis of rock powders by automatic X-ray fluorescence. Chem. Geol., 5:7-86.

Leeman, W. P., Budahn, J. R., Gerlach, D. C., Smith, D. R., and Powell, B. N., 1980. Origin of Hawaiian tholeiites: Trace element constraints. Am. J. Sci., 280A:794-819.

Macdonald, G. A., and Katsura, T., 1964. Chemical composition of Hawaiian lavas. J. Petrol., 5:82-133.

Miyashiro, A., Shido, F., and Ewing, M., 1969. Diversity and origin of abyssal tholeiite from the Mid-Atlantic Ridge near $24^{\circ}$ and $30^{\circ}$ North latitude. Contrib. Mineral. Petrol., 23:38-52.

1971. Metamorphism in the Mid-Atlantic Ridge near $24^{\circ}$ and $30^{\circ}$ N. Phils. Trans. R. Soc. London, A268:589-603.

Moore, J. G., 1970. Water content of basalt erupted on the ocean floor. Contrib. Mineral. Petrol., 28:272-279.

Moore, J. G., and Schilling, J. G., 1973. Vesicles, water and sulphur in Reykjanes Ridge basalts. Contrib. Mineral. Petrol., 41:105-118.

Mullen, E. D., 1983. $\mathrm{MnO} / \mathrm{TiO}_{2} / \mathrm{P}_{2} \mathrm{O}_{5}: \mathrm{A}$ minor element discriminant for basaltic rocks of oceanic environments and its implications for petrogenesis. Earth Planet. Sci. Lett., 62:53-62.

Natland, J. H., 1979a. Crystal morphologies in basalts from DSDP Site $395,23^{\circ} \mathrm{N}, 46^{\circ} \mathrm{W}$, Mid-Atlantic Ridge. In Melson, W. G., Rabinowitz, P. D., et al., Init. Repts. DSDP, 45: Washington (U.S. Govt. Printing Office), 423-445.

$1979 b$. Comparison of chemical and magnetic stratigraphy of basement rocks at DSDP Sites 332 and 395. In Melson, W. G.,
Rabinowitz, P. D., et al., Init. Repts. DSDP, 45: Washington (U.S. Govt. Printing Office), 657-677.

1980. Effect of axial magma chambers beneath spreading centers on the compositions of basaltic rocks. In Rosendahl, B. R., Hekinian, R., et al., Init. Repts. DSDP, 54: Washington (U.S. Govt. Printing Office), 833-850.

Norrish, K., and Hutton, J. T., 1969. An accurate X-ray spectrographic method for the analysis of a wide range of geological samples. Geochim. Cosmochim. Acta, 33:431-453.

O'Hara, M. J., and Mathews, R. E., 1981. Geochemical evolution in an advancing, periodically replenished, periodically tapped, continuously fractionated magma chamber. J. Geol. Soc., London, 138:237-278.

Ozima, M., Saito, K., and Takigami, Y., 1981. ${ }^{40} \mathrm{Ar} /{ }^{39} \mathrm{Ar}$ geochronological studies on rocks drilled at Holes 462 and $462 \mathrm{~A}$, Deep Sea Drilling Project, Leg 61. In Larson, R. L., Schlanger, S. O., et al., Init. Repts. DSDP, 61: Washington (U.S. Govt. Printing Office), 701-703.

Pearce, J. A., 1975. Basalt geochemistry used to investigate past tectonic environments on Cyprus. Tectonophysics, 25:41-68. 1976. Statistical analysis of major element patterns in basalts. J. Petrol., 17:15-43.

Pearce, J. A., and Cann, J. R., 1973. Tectonic setting of basic volcanic rocks determined using trace element analyses. Earth Planet. Sci. Lett., 19:290-300.

Pearce, J. A., and Norry, M. J., 1979. Petrogenetic implications of Ti, $\mathrm{Zr}, \mathrm{Y}$ and $\mathrm{Nb}$ variations in volcanic rocks. Contrib. Mineral. Petrol., 69:33-47.

Pritchard, R. G., Cann, J. R., and Wood, D. A., 1979. Low-temperature alteration of oceanic basalts, DSDP Leg 49. In Luyendyk, B. P., Cann, J. R., et al., Init. Repts. DSDP, 49: Washington (U.S. Govt. Printing Office), 709-714.

Sato, H., 1977. Nickel content of basaltic magmas: Identification of primary magmas and a measure of the degree of olivine fractionation. Lithos, 10:133-120.

Schilling, J.-G., and Winchester, J. W., 1969. Rare earth contribution to the origin of Hawaiian lavas. Contrib. Mineral. Petrol., 23: 27-37.

Schlanger, S. O., and Premoli Silva, I., 1981. Tectonic, volcanic and paleogeographic implications of redeposited reef faunas of Late Cretaceous and Tertiary age from the Nauru Basin and the Line Islands. In Larson, R. L., Schlanger, S. O., et al., Init. Repts. DSDP, 61: Washington (U.S. Govt. Printing Office), 817-827.

Sparks, R. S. J., Meyer, P., and Sigurdsson, H., 1980. Density variation amongst mid-ocean ridge basalts: Implications for magma mixing and the scarcity of primitive lavas. Earth Planet. Sci. Lett., 46:419-430.

Sun, S. S., and Nesbitt, R. W., 1977. Chemical heterogeneity of the Archaean mantle, composition of the earth and mantle evolution. Earth Planet. Sci. Lett., 35:429-448.

Sun, S. S., Nesbitt, R. W., and Sharaskin, A. Y., 1979. Geochemical characteristics of mid-ocean ridge basalts. Earth Planet. Sci. Lett. 44:119-138.

Tarney, J., Saunders, A. D., Weaver, S. D., Donnellan, N. C. B., and Hendry, G. L., 1979. Minor-element geochemistry of basalts from Leg 49, North Atlantic Ocean. In Luyendyk, B. P., Cann, J. R., et al., Init. Repts. DSDP, 49: Washington (U.S. Govt. Printing Office), 657-691.

Thompson, R. N., 1982. Magmatism of the British Tertiary volcanic province. Scott. J. Geol., 18:49-107.

Thompson, R. N., Morrison, M. A., Dickin, A. P., and Hendry, G. D., 1983. Continental flood basalts... arachnids rule OK? In Hawkesworth, C. J., and Norry, M. J. (Eds.), Continental Basalts and Mantle Xenoliths: Nantwich (Shiva Publishing Ltd., U.K.), pp. 158-185.

Tokuyama, H., and Batiza, R., 1981. Chemical composition of igneous rocks and origin of the sill and pillow basalt complex of Nauru Basin, southwest Pacific. In Larson, R. L., Schlanger, S. O., et al., Init. Repts. DSDP, 61: Washington (U.S. Govt. Printing Office), 673-688.

Walsh, J. N., Buckley, F., and Barker, J., 1981. The simultaneous determination of the rare earth elements in rock using inductively coupled plasma source spectrometry. Chem. Geol., 33:141-153.

Windom, K. E., and Book, P., 1981. Vein minerals in basalt, Hole 462A, Leg 61 of the Deep Sea Drilling Project. In Larson, R. L., 
Schlanger, S. O., et al., Init. Repts. DSDP, 61: Washington (U.S. Govt. Printing Office), 647-651.

Winterer, E. L., 1973. Regional problems. In Winterer, E. L., Ewing, J. I., et al., Init. Repts. DSDP, 17: Washington (U.S. Govt. Printing Office), 911-922.

Wood, D. A., 1978. Major and trace element variations in the Tertiary lavas of eastern Iceland and their significance with respect to the Iceland geochemical anomaly. J. Petrol., 19:393-436.
Wood, D. A., Gibson, I. L., and Thompson, R. N., 1976. Element mobility during zeolite facies metamorphism of the Tertiary basalts of eastern Iceland. Contrib. Mineral. Petrol., 55:241-254.

Date of Initial Receipt: 8 March 1984

Date of Acceptance: 4 July 1984
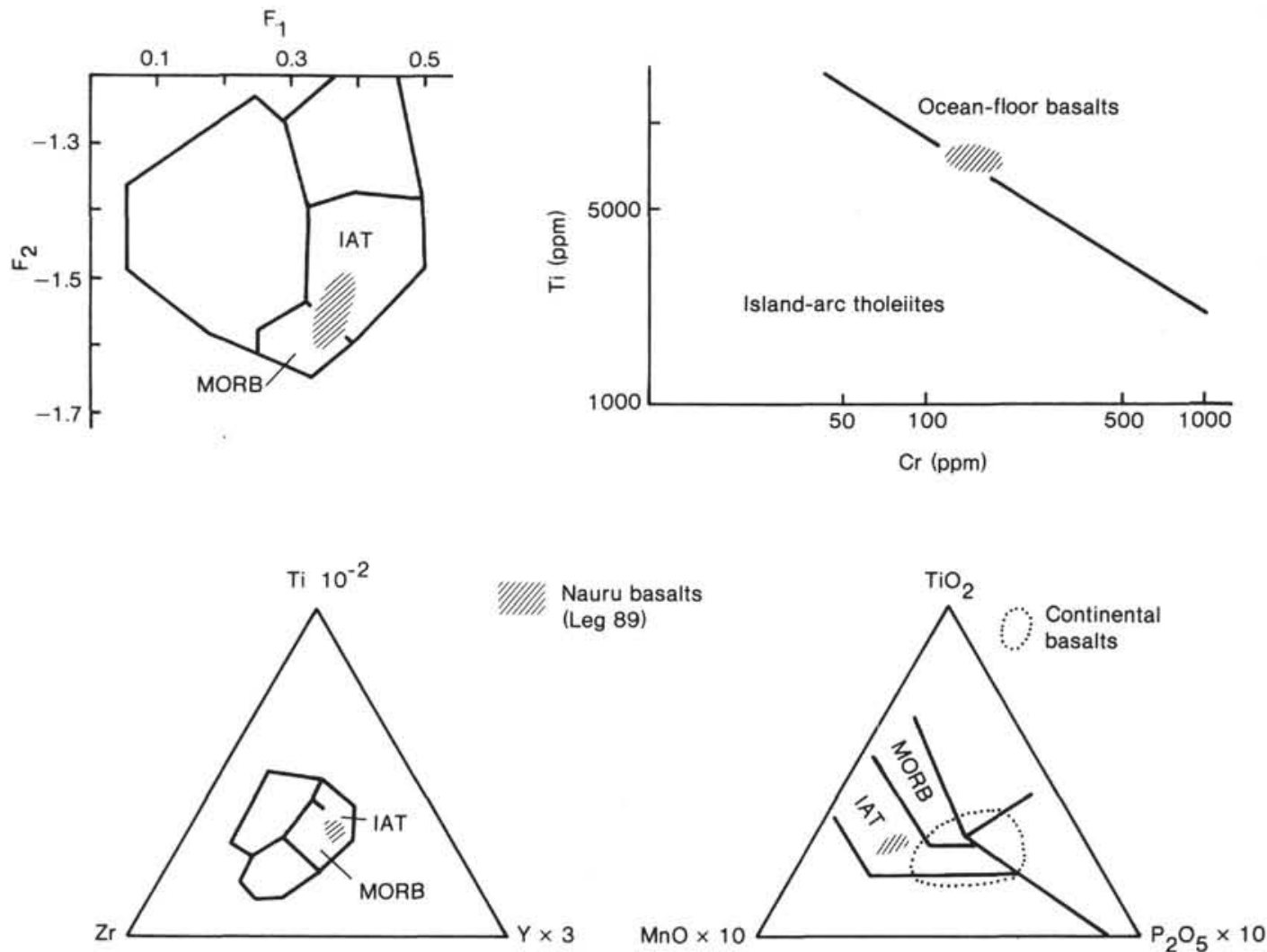

Figure 16. Distribution of Hole 462A (Leg 89) basalts in various tectonic discrimination diagrams. Diagrams from Pearce and Cann (1973), Pearce $(1975,1976)$, and Mullen (1983). $F_{1}$ and $F_{2}$ are major element discriminant functions (Pearce, 1976). MORB = mid-ocean ridge basalt field; IAT $=$ island arc tholeiite field. 


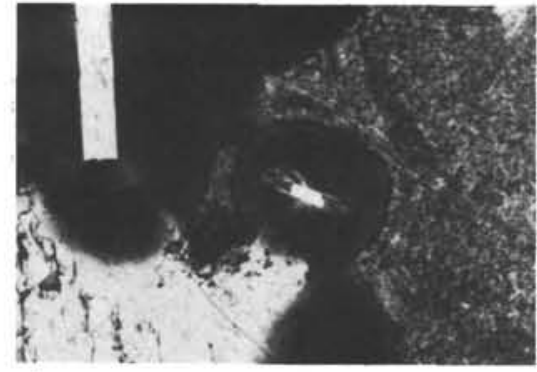

1

$0.1 \mathrm{~mm}$

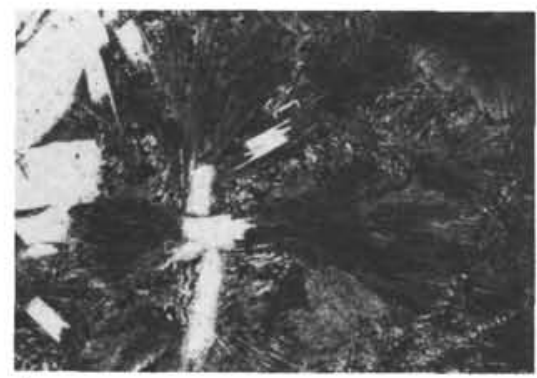

4

$0.1 \mathrm{~mm}$

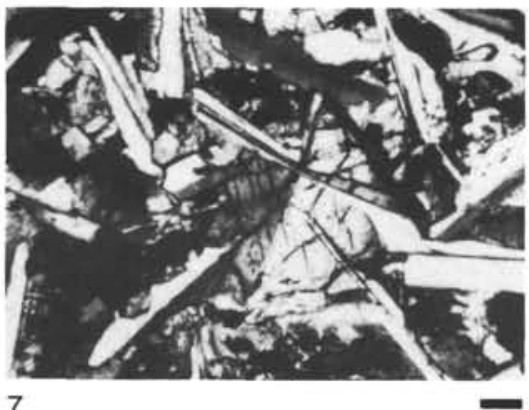

$0.1 \mathrm{~mm}$

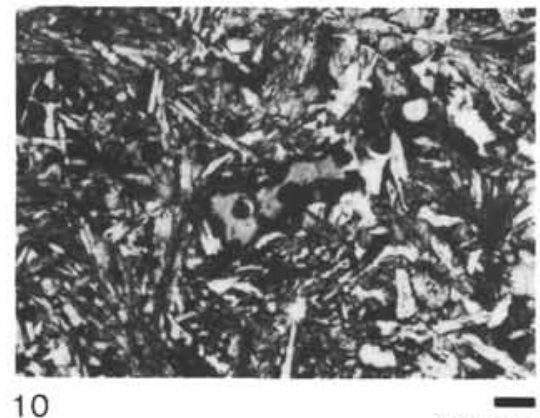

$0.1 \mathrm{~mm}$

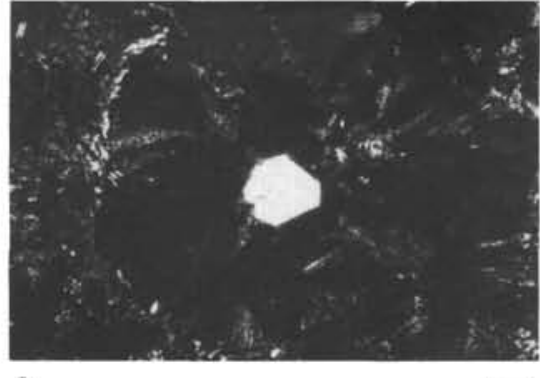

2

$0.1 \mathrm{~mm}$

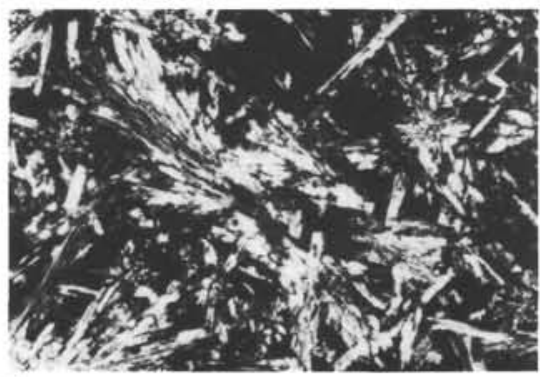

$0.1 \mathrm{~mm}$

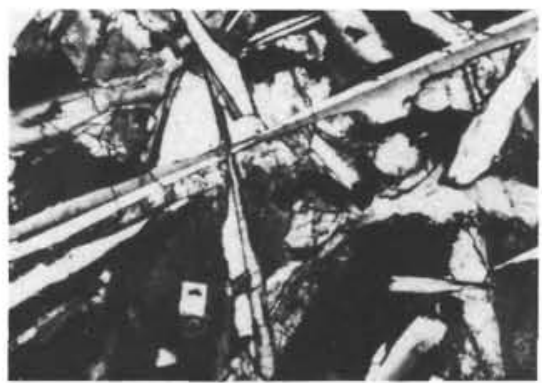

8

$0.1 \mathrm{~mm}$

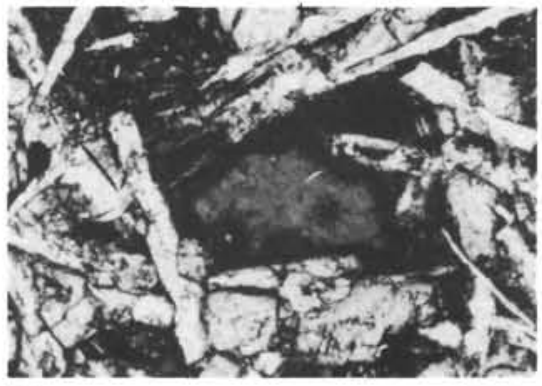

11

$0.1 \mathrm{~mm}$

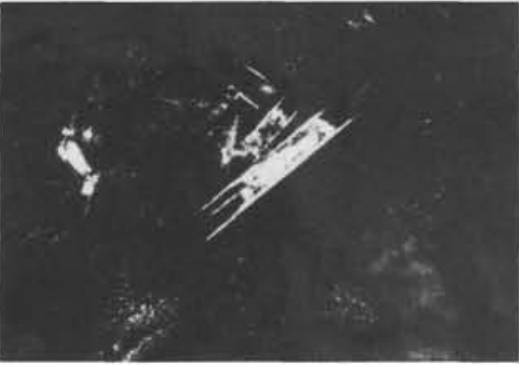

3

$0.1 \mathrm{~mm}$

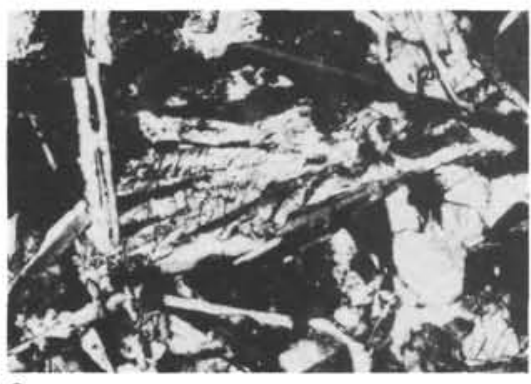

6

$0.1 \mathrm{~mm}$

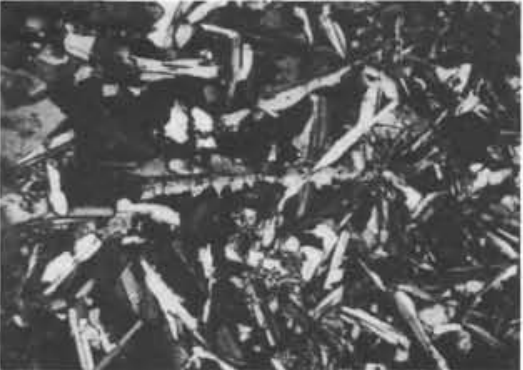

9

Plate 1. Photomicrographs illustrating petrographic and textural features of Hole 462A (Leg 89 ) submarine sheet-flow basalts (ppl = plane polarized light; $\mathrm{xp}=$ crossed polars). 1. Dark magnetite-rimmed pyroxene spherulites nucleated on skeletal plagioclase microphenocrysts. The original vitreous matrix is replaced by clear palagonite and granular smectite, Sample 462A-103-1, 60-61 cm (ppl). 2. Fibrous pyroxene spherulite nucleated on clinopyroxene microphenocryst core, Sample 462A-102-5, 5-9 cm (xp). 3. Skeletal tuning-fork plagioclase microlites in an essentially opaque hyalopilitic groundmass, Sample $462 \mathrm{~A}-102-4,59-63 \mathrm{~cm}$ (ppl). 4. Plumose clinopyroxene variolite nucleated on terminations of plagioclase microphenocrysts, Sample 462A-103-1, 60-61 cm (ppl). 5. Plumose clinopyroxene bundles, Sample 462A-102-4, 131-136 cm (xp). 6. Well-spaced clinopyroxene blades containing small dark inclusions in an open-structured variolite, Sample 462A-101-2, 117-122 cm (xp). 7. Skeletal serrated plagioclase partly enclosed in a central, twinned clinopyroxene "nucleus," Sample 462A-101-4, 115-120 cm (xp). 8. Cruciform plagioclase bowties subophitically enclosed in a clinopyroxene "nucleus," Sample 462A-101-4, 57-61 cm (xp). 9. Open-structured variolite of skeletal twinned clinopyroxene and plagioclase, Sample 462A-106-2, 3-4 cm (xp). 10. Palagonite-replaced interstitial glass with a margin of dark smectite, Sample 462A-103-1, 107-112 cm (ppl). 11. Interstitial palagonite replaced by a thin marginal zone and inward-growth hemispheres of fibrous smectite, Sample 462A-105-2, 4-5 cm (ppl). 12. Interstitial palagonite replaced by vermicules of dark smectite along relict perlitic cracks, Sample 462A-101-4, 115-120 cm (ppl). 


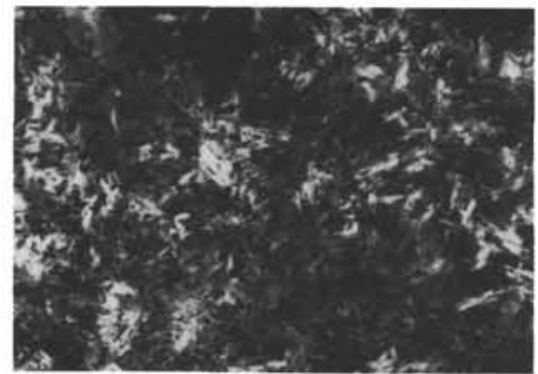

$0.2 \mathrm{~mm}$

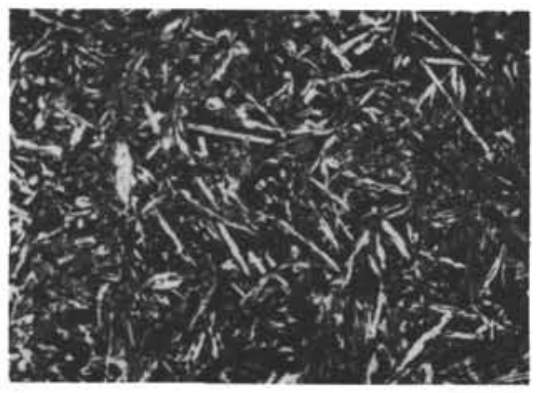

4

$0.5 \mathrm{~mm}$

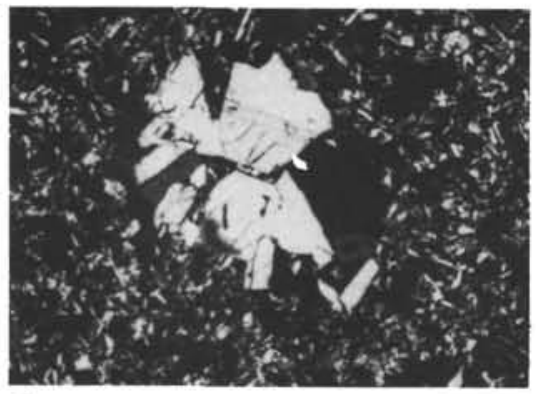

7

$0.5 \mathrm{~mm}$

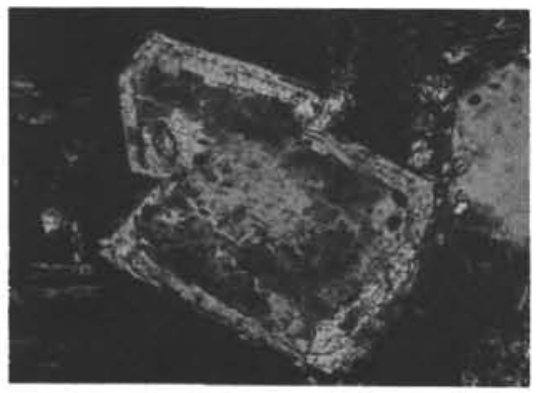

10

$0.1 \mathrm{~mm}$

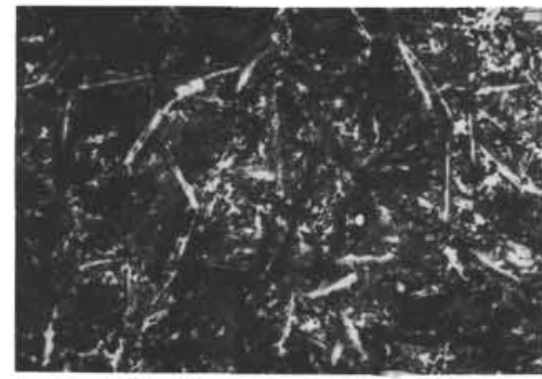

2

$0.2 \mathrm{~mm}$

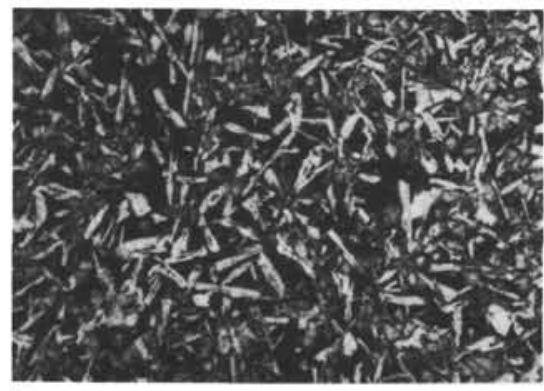

5

$0.5 \mathrm{~mm}$

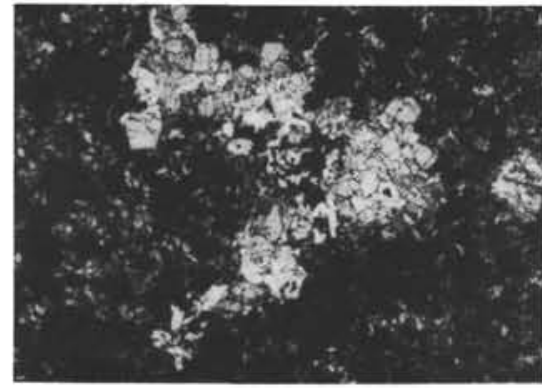

8

$0.5 \mathrm{~mm}$

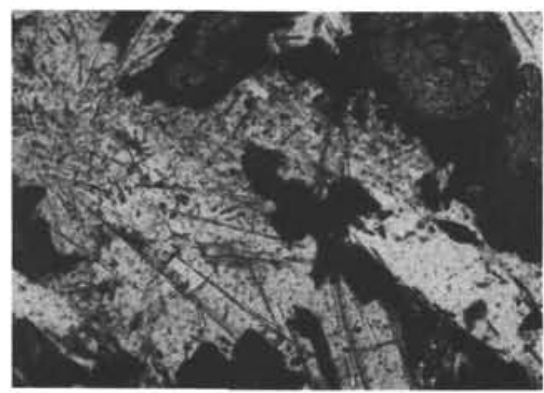

11

$0.1 \mathrm{~mm}$
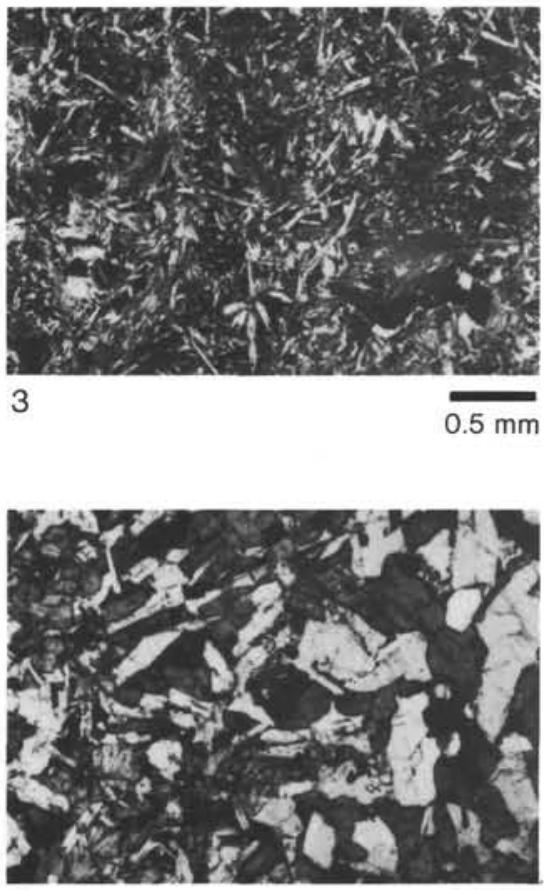

6

$0.5 \mathrm{~mm}$

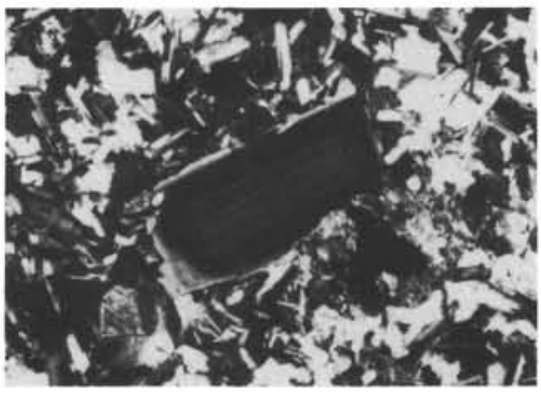

9

$0.2 \mathrm{~mm}$

Plate 2. Photomicrographs illustrating petrographic and textural features of Hole $462 \mathrm{~A}(\mathrm{Leg} 89)$ submarine sheet-flow basalts (ppl $=$ plane polarized light; $\mathrm{xp}=$ crossed polars). 1. Hyalopilitic texture of quenched clinopyroxene plumes and magnetite grains, Sample 462A-98-6, 41-46 $\mathrm{cm}$ (ppl). 2. Slightly coarser quench fabric than in Fig. 1, with clinopyroxene plumes, plagioclase microlites, and minor glass, Sample 462A104-2, 128-133 cm (ppl). 3. Variolitic clinopyroxene plumes and dark smectite-replaced interstitial glass, Sample 462A-102-4, 131-136 cm (ppl). 4. Coarser-grained quench fabric of clinopyroxene plumes and serrated plagioclase blades, Sample 462A-100-2, 61-66 cm (ppl). 5. Intersertal texture with interstitial glass, Sample 462A-108-2, 40-44 cm (ppl). 6. Coarse-grained intersertal to granular texture typical of holocrystalline flow interiors, Sample 462A-106-3, 4-8 cm (ppl). 7. Carlsbad-twinned plagioclase glomerocrysts, Sample 462A-95-5, 99-104 cm (xp). 8. Glomerocrystic group of granular clinopyroxene and plagioclase, Sample $462 \mathrm{~A}-95-5,61-63 \mathrm{~cm}$ (ppl). 9. Finely zoned plagioclase microphenocryst, Sample 462A-95-7, 38-43 cm (xp). 10. Plagioclase microphenocryst partially replaced by flaky smectite, Sample 462A-99-1, 119-122 $\mathrm{cm}$ (ppl). 11. Acicular zeolite needles and dark smectite in a plagioclase-rich area of coarse holocrystalline flows, Sample 462A-101-4, 115-120 $\mathrm{cm}(\mathrm{ppl})$. 12. Plagioclase alteration domain with replacive albite, $\mathrm{K}$-feldspar, and dark smectite, Sample $462 \mathrm{~A}-102-1,35-39 \mathrm{~cm}(\mathrm{xp})$. 